\author{
Universidade de São Paulo \\ Faculdade de Filosofia, Letras e Ciência Humanas \\ Departamento de Geografia
}

\title{
O movimento da economia financeira na dinâmica imobiliária de São Paulo
}

Sávio Augusto de Freitas Miele

São Paulo

Junho de 2007 
Universidade de São Paulo

Faculdade de Filosofia, Letras e Ciência Humanas

Departamento de Geografia

\section{O movimento da economia financeira na dinâmica imobiliária de São Paulo}

\section{Sávio Augusto de Freitas Miele}

Dissertação apresentada à Faculdade de Filosofia, Letras e Ciências Humanas da Universidade de São Paulo como parte dos requisitos para obtenção do Título de Mestre em Geografia Humana.

Orientadora: Profa Dra Ana Fani Alessandri Carlos

São Paulo

Junho de 2007 
Aos meus pais. 


\section{Agradecimentos}

Primeiramente gostaria de prestar meus agradecimentos às pessoas que contribuíram com suas entrevistas para a realização desta dissertação. Muito obrigado à Rosana da biblioteca da Sehab, que apareceu de última hora, mas que com sua crença na importância de nosso trabalho e de que ele se realiza também coletivamente me ajudou muito na busca por dados.

Às secretárias da Pós-Graduação do Departamento de Geografia, que sempre foram muito gentis.

À CAPES pela bolsa de pesquisa concedida para a elaboração desta dissertação.

Meus agradecimentos ao André que topou entrar na correria e nos prazos finais para elaborar os mapas deste trabalho.

Aos amigos do grupo de estudos e ao pessoal do Labur.

Aos amigos do GESP: Frederico, Júlio, Júnior e Renata. Ao Júnior e Renata, novamente, pela elaboração dos gráficos sobre mercado imobiliário de escritórios, muito obrigado mesmo!

À Flor, amiga de todas as horas, sempre disposta a ajudar, a escutar. Além de ter um astral sempre lá no alto!

Às amigas Camila e Fabiana, pessoas muito queridas com quem venho dividindo momentos especiais de trabalho, viagens, festas. Espero que ainda por muito mais tempo!

Ao Danilo e ao Rafael, meus amigos de vida e geografia! Amizade e parceria que quero levar sempre comigo.

Ao meu tio Marcelo por ter me recebido em sua casa em Orlândia, no interior de São Paulo, onde pude me concentrar na finalização deste trabalho.

À Prof ${ }^{\mathrm{a}}$ Fani pela orientação cotidiana, paciência e, sobretudo, pela confiança em mim. Nossa convivência durante esses sete anos tem sido essencial para minha formação e também marcante em minha vida. Obrigado pelos incentivos de sempre!

Ao Dr. Walfrido, agradeço a presença e a ajuda que me deu nos últimos dias de elaboração do trabalho.

Aos meus queridos irmãos Ana Helena e Aluísio pela compreensão, nem sempre tão fácil, porém pessoas sempre presentes!

Por fim, agradeço imensamente apoio incondicional de minha mãe nas escolhas que venho tomando em minha vida. 


\section{RESUMO}

O presente trabalho procura revelar que a produção do espaço urbano em um fragmento da metrópole de São Paulo se realiza através de investimentos do capital financeiro (ou por parte dessa fração de capital) no setor imobiliário. Trata-se de inversões do capital financeiro em empresas incorporadoras e construtoras e em seus projetos que ao se realizarem produzem um novo espaço na metrópole. São analisados nesta pesquisa três Fundos de Investimentos Imobiliários e as grandes empresas empreendedoras imobiliárias que abriram capital na bolsa de valores, como forma de financiamento para projetos imobiliários. Não se trata da descoberta do setor imobiliário e a grande quantidade de capital que este setor necessita e sua relação direta com a (re)produção do espaço urbano, mas de um movimento de financeirização do imobiliário, que surge hoje como elemento central para a reprodução da esfera financeira do capital tendo como condição e meio o espaço tornado mercadoria e como produto a metrópole contemporânea, que possui como uma de suas características a articulação com o plano do mundial.

Entretanto observamos em nossa pesquisa sobre o movimento da economia financeira na dinâmica imobiliária em São Paulo, que a produção material do espaço traz em si algo que a nega. Em que medida o próprio espaço, que é condição e meio para o processo, colocaria barreira para esse processo de financeirização do imobiliário e do capital financeiro se realizando através da produção do espaço? Esta questão então possui uma dimensão teórica e prática. Teórica porque ela traz a negatividade do processo e prática porque o próprio espaço elemento central para que o processo aqui em evidência se realize, torna-se barreira, limite a ser superado. Encontramo-nos diante de uma contradição do espaço. Como o espaço se torna barreira para a sua própria produção? No sentido aqui exposto a produção capitalista do espaço revela que tal processo contém uma negatividade interna que ao se manifestar enquanto cisão é motivo para um movimento de superação, continuidade e novas contradições. Na constituição deste mercado imobiliário, no contexto da produção da metrópole contemporânea, lê-se que existe um movimento que rompe com a lógica formal e revela um movimento dialético.

Palavras Chave: Produção do espaço, São Paulo, Financeiro, Imobiliário, Metrópole 


\begin{abstract}
This work, aims to reveal that the production of urban space in a fragment of São Paulo metropolis is happening through financial capital investments in the real estate business. There are financial capital investments in enterprises of real estate business and in its projects producing a new space in São Paulo Metropolis. Three Real Estate Investment founds were analyzed and the bigger real estate business enterprises which have done yours IPO in 2006 as a way to finance real state projects. It's not the discovery of the real estate business and its relation with the financing area, but the union between the real estate business with the financial capital producing the urban space.

However we observe in our research that the material production of space brings in itself something that denies it. How the space itself, that is condition and way to the process can be a limit to its production? This question has a theory and practical dimension. It brings the negative dimension of the process and practical, because space, important element to the process is a limit to its production. There is in this process a contradiction of space.
\end{abstract}

Key-words: Production of space, São Paulo, Financial, Real Estate, Metropolis 


\section{SUMÁRIO}

Introdução... p.08

\section{Capítulo 1}

A produção do espaço em São Paulo na perspectiva de constituição de um mercado imobiliário crítico. ..p.16

Capítulo 2

Os fundos de investimento imobiliário (FIIs). ..p.67

Capítulo 3

As empresas imobiliárias e a abertura de capital na bolsa de valores p.121

Considerações Finais p.127 


\section{Introdução}

A cidade e o urbano tornam-se centrais para a análise do momento atual porque é o espaço da reprodução em vários níveis. A complexidade do fenômeno urbano abriga a vida social em todas as suas dimensões, assim a análise da cidade e do urbano não prescinde de uma articulação entre o econômico, o político e o social. Se o fenômeno urbano diz respeito à vida do homem e ao humano, faz-se necessário pensar a realização dessa humanidade em suas múltiplas dimensões, bem como as mediações que atravessam as relações sociais, num movimento do qual emergem contradições; centrais para a análise da cidade (ainda mais num momento em que as relações sociais deixam de ser marcadas por uma imediaticidade e tornam-se cada vez mais mediatas).

O processo de urbanização da metrópole de São Paulo se realiza aprofundando contradições num momento em que as determinações econômicas se colocam como fundamentais na produção da cidade como negócio, evidenciando a centralidade da propriedade privada da terra na produção do espaço urbano e na conformação da metrópole paulistana. A reflexão sobre o momento atual por que passa a urbanização da metrópole de São Paulo e o conteúdo deste processo, que a partir do momento em que deixa de ser induzido pela industrialização e passa a ser o indutor das práticas do homem $^{1}$, passa a ser um processo revelador da própria vida do homem na cidade, como produtor de seu espaço e de sua existência material e concreta. O processo de urbanização pode revelar, no plano espacial, as estratégias de reprodução do espaço, do capital e da vida na cidade. A complexidade do processo de (re)produção do espaço urbano nos revela novos processos e sujeitos sociais que surgem no constante movimento de reprodução espacial.

Neste contexto, o processo de urbanização da metrópole paulista parece se concretizar ao passo que ganha novas formas e novos conteúdos relacionados ao capitalismo contemporâneo, marcado, de modo geral, por uma reestruturação produtiva na indústria e uma financeirização da economia. Entretanto temos consciência de que é no processo produtivo que acontece a extração do excedente (condição da acumulação) e a produção da riqueza no modo de produção capitalista, porém comandado por um sistema financeiro cada vez mais presente, que passa a ser elemento central na

\footnotetext{
${ }^{1}$ Processo analisado por Henri Lefebvre no Capítulo I da obra “O direito à cidade”.
} 
reprodução das relações de produção. As finanças passam de produto a produtoras de relações sociais, abrindo caminho para sua primazia econômica.

O que sustenta objetivamente a reflexão teórica aqui empreendida é a realidade urbana da metrópole de São Paulo, pois sua urbanização contém processos reais e concretos que efetivamente encontram-se articulados aos nexos de reprodução capitalista mais profundos e atuais (nexos da realização do valor) que possuem a potência de transformar a prática sócio-espacial (o que revela o plano da vida na metrópole). Neste sentido, a metrópole aparece como mediação entre duas instâncias: as relações mais gerais da sociedade e as relações sociais tecidas no plano da vida cotidiana; essa articulação ocorre concretamente na (re)produção do espaço urbano.

A problemática levantada para pesquisa que realizamos está ligada à articulação entre o financeiro e o imobiliário no processo de produção do espaço urbano; no movimento crescente de financeirização do setor imobiliário. Partimos da hipótese de que a partir desta relação entre circuitos financeiros e o setor imobiliário, a produção do espaço surge como condição para a realização do capital financeiro aplicado no setor imobiliário. A produção do espaço se torna condição para a reprodução do capital, sobretudo de sua fração financeira. Não se trata da descoberta do setor imobiliário e a grande quantidade de capital de que necessita este setor da economia e sua relação direta com a (re)produção do espaço urbano, mas de um movimento de financeirização do imobiliário, que surge hoje como elemento importante para a reprodução da esfera financeira do capital tendo como condição e meio o espaço tornado mercadoria e como produto a metrópole contemporânea, que possui como uma de suas características a articulação com o plano do mundial. Partindo desta idéia, observamos que a produção do espaço urbano, bem como desenvolvimento do mercado imobiliário possui limites, expressos pelas contradições internas ao processo de produção capitalista do espaço. Além disso, tanto o mercado imobiliário como o processo de reprodução espacial se realizam por empreendimento de estratégias, pela busca de uma lógica e racionalidade que são rompidas, pois o próprio processo aqui em questão pode se tornar barreira para sua reprodução. Assim, no desenvolvimento do trabalho no sentido de buscar respostas às questões iniciais, alcançamos a idéia de que o processo de produção do espaço como condição para realização de diversos capitais, bem como de sua valorização (isso empreendido por sujeitos sociais presos aos ditames da acumulação capitalista) traz algo que o nega, mas uma negatividade interna ao processo que aparece como possibilidade de expansão do processo produzindo novas contradições, superando outras. 
Através da análise de um fragmento da metrópole de São Paulo - o eixo econômico financeiro e de serviços que se expande do centro em direção ao sudoeste/sul da metrópole (conhecido também como vetor sudoeste) - observamos a constituição de um mercado imobiliário destinado a edifícios de escritórios corporativos que se constitui com a união de grupos econômicos da metrópole e o Estado, com a presença cada vez maior de investimentos de capital financeiro nos negócios imobiliários. São analisados nesta pesquisa os Fundos de Investimento Imobiliário (localizados neste fragmento) e as grades empresas empreendedoras imobiliárias que abriram capital na bolsa de valores como forma de financiamento para projetos imobiliários - ampliando aqui a análise sobre o imobiliário residencial.

Nossa preocupação está voltada para a construção de um caminho possível para a compreensão de como o processo de reprodução do espaço na metrópole de São Paulo, especificamente no fragmento do eixo empresarial da metrópole, é incorporado pelas novas estratégias de acumulação de capital e como possibilidade de realização do capital financeiro no setor imobiliário, por meio da análise de três empreendimentos imobiliários - três edifícios corporativos destinados a escritórios - construídos através da constituição de fundos de investimento imobiliário ou que fazem parte desses fundos, sendo eles o Fundo Financial Center de Investimento Imobiliário (tendo como empreendedor a Brazil Realty e como administrador o Unibanco), o Fundo de Investimento Imobiliário Torre Norte (uma das três torres do Complexo Empresarial Nações Unidas, que foi estruturado pela Brazilian Mortgages e administrado pelo banco Ourinvest) e o Fundo de Investimento Imobiliário Continental Square Faria Lima (estruturado e administrado pela Unitas DTVM). Com relação às empresas empreendedoras imobiliárias que abriram capital na bolsa de valores de São Paulo, vamos abordar a temática dando maior destaque à empresa Company SA.

O que chamamos aqui de fragmento está associado à expansão do centro de São Paulo em direção ao sudoeste/sul da metrópole. Trata-se, em linhas gerais, do desdobramento da centralidade da cidade de São Paulo que engloba a avenida Paulista e atinge a região da avenida Luiz Carlos Berrini e Marginal do rio Pinheiros. É justamente nesse eixo que encontramos uma grande concentração de edifícios de escritórios, bem como a grande parte das sedes de empresas nacionais e multinacionais e de serviços mais sofisticados existentes na metrópole, dos circuitos financeiros da economia até os serviços de informática e telecomunicações, passando pelos serviços de consultorias internacionais. Além disso, se faz necessário destacar, como o faremos mais adiante, o 
contexto particular em que essa região se constituiu / se constitui como um eixo empresarial que possui aí concentrados os maiores investimentos em infra-estrutura urbana da metrópole.

A denominação fragmento está articulada à noção de totalidade, bem como a forma como se vive fragmentariamente os “pedaços” da metrópole.

Seria a totalidade dada no fato? Seria determinada pela análise que pretendemos realizar? Ou seria a totalidade uma síntese? Seria a totalidade reconstruída pelo pensamento? Entendemos que a totalidade não nos aparece como uma mera soma de fatos e processos, mas que vai sendo construída no desenrolar do processo de desvendamento da realidade por meio do movimento do pensamento. Propomo-nos a entender a cidade em sua totalidade - uma totalidade dialética, móvel e aberta - e, assim elencar os elementos que conduzam a uma análise que contemple os processos e os fenômenos e suas respectivas relações, os quais nos levam a um entendimento da realidade. Desta forma, compreendemos que a totalidade não é dada no fato... (Miele, 2004:2728).

Isso nos leva ao entendimento de que não nos parece possível alcançar uma compreensão do processo de reprodução espacial do fragmento aqui em questão sem realizar as devidas articulações com a mundialidade do espaço, bem como sua inserção no processo produtivo capitalista como mercadoria e da constituição de uma sociedade urbana. Não se trata de um fragmento isolado. A relação entre ele (eixo empresarial) e o momento atual da urbanização de São Paulo deve estar presente no sentido de não entendermos as regiões que compõem tal fragmento como se houvesse várias cidades dentro da cidade ou mesmo estudar a cidade como um conjunto de sistemas. Compreendemos este fragmento articulado ao momento de reprodução espacial da metrópole paulistana. O processo posto aqui em evidência possui desdobramentos outros que podemos apontar, mas não aprofundar neste trabalho.

O ponto de partida para análise é a dimensão econômica e política que está no bojo deste processo. Aprofundar essas dimensões não significa desprezar o plano do social. Muito pelo contrário. O plano do social aparece no horizonte, teórico e praticamente como um desafio desta análise. 
Primeiramente, como estamos afirmando neste trabalho, o processo que procuramos desvendar no contexto da produção do espaço urbano da metrópole de São Paulo é um momento de sua urbanização hoje. Temos ciência da forma como esse processo, que possui sua tônica dominante na economia com intensa presença do Estado, domina a cidade e o urbano nos colocando frente a imensos desafios teóricos e práticos quando refletimos a dimensão do social e da vida cotidiana.

É neste plano que é vivida a segregação sócio-espacial como fruto da homogeneização/fragmentação/hierarquização do espaço. Para Lefebvre, a homogeneização se refere aos elementos no e do espaço, que se repetem no espaço e o compõe. Esses elementos entendidos numa relação dialética entre forma-conteúdo e que necessariamente não são os mesmos nem iguais, mas guardam o sentido da reprodução capitalista, em uma articulação entre o local e o mundial; o espaço entendido aqui em sua dimensão mental, geométrica. A idéia de fragmentação está ligada ao entendimento do espaço partido, quebrado, dividido em pedaços. Afirma Lefebvre,

Quanto aos recortes e fragmentações, eles vão até o infinito ... Os escritos especializados informam a seus leitores sobre todos os tipos de espaços precisamente especializados: espaços de lazer, de trabalho, dos transportes, equipamentos, etc. Outros não hesitam em falar de "espaço doente" ou de "doença do espaço", do espaço louco ou do espaço da folia... ${ }^{2}$ (Lefebvre, 2000:14-15).

Ainda nestes termos temos que levar em consideração as estratégias dos promotores imobiliários que vendem estes pedaços no mercado, colocando em evidência a existência da propriedade privada da terra que vai abrir caminho para a discussão da vitória do valor de troca sobre o valor de uso e para a discussão a respeito da hierarquização do espaço. Ou seja, os espaços valorizados, os não valorizados, o centro e a periferia, os lugares nobres da cidade, os guetos urbanos e o próprio planejamento guardião das leis de uso e ocupação do solo urbano. Ainda sobre a tríade, o Autor escreve:

\footnotetext{
${ }^{2}$ Tradução do autor.
} 
Como um espaço pode ser ao mesmo tempo homogêneo e quebrado? Não seria um absurdo, uma impossibilidade? Não. Este espaço é homogêneo porque tudo é equivalente, permutável, intercambiável. Este espaço é quebrado porque é tratado por lotes e parcelas. ${ }^{3}$ (Lefebvre, 1978:292-293).

A produção do espaço urbano neste fragmento da metrópole, o eixo empresarial, é marcado por um contínuo processo de construção/desconstrução/reconstrução do espaço e do que o conforma para a constante relocalização de atividades econômicas na metrópole que acaba por destruir bairros constituídos e retiram favelas que nesses espaços foram construídas para que os indesejáveis, o sujo e o feio deixem os lugares mais valorizados da cidade ou lugares de valorização futura para reconstruírem suas vidas, "sabe-se lá como”, a quilômetros de distâncias dali, seja num conjunto habitacional precário ou mesmo em outras favelas em áreas de mananciais da cidade, por exemplo ${ }^{4}$. No limite, para os sujeitos que se aliam para a construção desses espaços, os habitantes e a realização de suas vidas não os interessam. Este processo ocorre com a união / aliança dos interesses do Estado e de uma elite que detém o poder econômico na cidade. O processo evidenciado neste trabalho de pesquisa aprofunda as negatividades do urbano, que são vividas no cotidiano da metrópole como constrangimentos e estranhamento. A produção do espaço nas áreas mais valorizadas da cidade denota a constituição de grupos que se aliam para garantirem a reprodução de seus capitais e de seu poder através da produção do espaço.

O sentido deste trabalho, além do que já foi exposto anteriormente, é também apontar criticamente um processo que sabemos que aumenta as diferenças, que são na realidade desigualdades e cisões presentes no processo de produção capitalista do espaço; revelar que os interesses do Estado e do capital não caminham no sentido de suprir as necessidades reais das classes pobres que habitam a imensa periferia metropolitana e sim de zelar pelos seus poderes (o poder político do Estado e o poder econômico do capital). É mostrar que neste processo há uma parcela da população que fica desamparada e sofre diversos constrangimentos em suas vidas, pois aprofunda a

\footnotetext{
3 Tradução do autor.

${ }^{4}$ O trabalho de Mariana Fix, "Parceiros da Exclusão”, trata exatamente desse processo de retirada de uma grande favela que existia no cruzamento das avenidas Luiz Carlos Berrini e Água Espraiada.
} 
existência de uma desigualdade de renda e uma desigualdade de poder ${ }^{5}$. A produção do espaço neste fragmento da metrópole revela a força política de uma classe economicamente capitalizada que ao se unir ao Estado mantêm seus interesses, que vão garantir sua reprodução enquanto tal. Através de um estudo sobre a produção do espaço urbano e a relação capital financeiro e setor imobiliário em um fragmento da metrópole de São Paulo, podemos afirmar que por dentro do modo de produção capitalista não há possibilidade de transformação social possível, pois a produção capitalista da cidade está atrelada ao processo de valorização do valor e existência da propriedade privada da terra. É a partir deste momento que se coloca como necessidade a idéia de um projeto de transformação da sociedade, que é urbana, numa articulação entre o possível e o impossível, mas que aqui neste trabalho de pesquisa ainda não estão consolidados os alicerces teóricos e práticos para este desafio.

No primeiro capítulo deste trabalho discutiremos a importância do estudo da produção do espaço, evidenciando que este processo, sob o modo de produção capitalista, encontra-se na lógica da valorização do valor e sendo assim, contém as determinações fundamentais do modo de produção. Sob o capitalismo, a produção social do espaço traz em si algo que possibilita sua reprodução ao mesmo tempo em que a nega. Trata-se dos limites e barreiras da produção do espaço e conseqüentemente para o capital. Estamos no plano das contradições do espaço. A partir destas colocações discutiremos a relação Estado, espaço a partir de uma exposição sobre a construção do eixo empresarial de São Paulo, bem como uma exposição de alguns dados sobre o mercado imobiliário de escritórios que se desenvolve no eixo empresarial.

No segundo capítulo, iniciamos nossa discussão sobre os Fundos de Investimento Imobiliário e o seu o papel na financeirização do imobiliário - na transformação de imóveis em ativos financeiros. Através das análises de quatro entrevistas que realizamos com profissionais deste mercado, revelamos os nexos desse instrumento financeiro e de financiamento imobiliário que tem como ponto nodal de seu desenvolvimento o aluguel como forma de rendimento. Além disso, procuramos mostrar a relação deste instrumento com o Estado, a questão da propriedade privada da terra e a possibilidade da transformação de imóveis em bens móveis, claro que através de diversas estratégias empreendidas pelo setor financeiro e imobiliário. Terminamos o capítulo descrevendo os edifícios que compõem os fundos em questão.

\footnotetext{
${ }^{5}$ Idéia de Flávio Villaça exposta no Colóquio Projetos Urbanos. Reconversão Industrial, realizado na Universidade Mackenzie em 18 de abril de 2007.
} 
No terceiro capítulo, vamos abordar a questão da abertura de capital na bolsa de valores de São Paulo realizada pelas maiores empresas empreendedoras imobiliárias que atuam em São Paulo. Através da análise de entrevistas realizadas com profissionais dessas empresas revelaremos os passos e estratégias necessárias para que a abertura se concretize, bem como suas ações frente esse momento em que se encontram capitalizadas. Para terminar faremos algumas associações e comparações com o mercado imobiliário residencial e de escritórios e discutiremos uma tendência cada vez maior da internacionalização do imobiliário na cidade de São Paulo.

No quarto capítulo, retomaremos a discussão sobre a produção do espaço completando, após a exposição da pesquisa realizada, o movimento do pensamento exposto no início do primeiro capítulo, isto é, sob o modo de produção capitalista o processo de produção do espaço possui algo que o nega, entretanto o nega superando para expandir seus limites, superando contradições. 


\section{Capítulo 1}

\section{A produção do espaço em São Paulo na perspectiva de constituição de um mercado imobiliário crítico}

É condição da análise geográfica a necessidade de refletir a respeito da produção do espaço. O que está em questão na compreensão e na concepção de Geografia aqui exposta é refletir como a sociedade se reproduz (re)produzindo o seu espaço (Carlos, 1994). Estudar o espaço significa compreender o movimento social que produz e reproduz tanto a sociedade como um todo quanto o próprio espaço. Assim, trata-se de considerar a espacialidade do processo social como intrínseca à análise geográfica. Esta espacialidade nos leva a afirmar que a Geografia se debruça sobre os processos sociais e a sociedade pelo viés de sua espacialização, o que vai nos colocar frente à dimensão concreta desses processos. Segundo Lefebvre, as relações sociais se realizam concretamente enquanto relações espaciais ${ }^{6}$, nos apontando que o homem, no decorrer de seu tempo histórico se relaciona com o outro produzindo materialmente um espaço e se produzindo como ser social. Para a Geografia, já faz parte de seu estatuto científico a preocupação a respeito do processo de produção do espaço. O que é importante é revelar o movimento desse processo sob o capitalismo, suas formas e estratégias de reprodução em vários momentos.

Vivemos um momento em que a produção do espaço se realiza por meio de diversas estratégias da reprodução capitalista. A racionalidade capitalista, cada vez mais, está presente na produção do espaço urbano, fazendo com que o espaço se torne uma mercadoria específica. Este movimento fica claro através do fato de que o espaço é vendido e trocado; essa condição dada ao espaço torna todo o espaço da cidade intercambiável. Outra questão é o espaço posto nos nexos da reprodução do capital, quando do processo de sua valorização.

\footnotetext{
${ }^{6}$ Anotações do curso Geografia Urbana I, ministrado pela Prof ${ }^{\mathrm{a}} \operatorname{Dr}^{\mathrm{a}}$ Ana Fani Alessandri Carlos em 1999.
} 
A produção do espaço e sua valorização parecem agora serem condições para a valorização de capitais do setor financeiro da economia aplicados no setor imobiliário, evidenciando um movimento entre a mundialização financeira (o processo produtivo no capitalismo comandado por um sistema financeiro, elemento importante na reprodução das relações de produção) e sua relação com a produção do espaço urbano. Harvey (1984) afirma que

a reprodução de configurações espaciais pode ser tratada ... como um momento ativo dentro da dinâmica temporal global de acumulação $e$ reprodução do capital ...

Desta forma, a produção atual do espaço pode ser entendida como um processo implicado na reprodução de capitais, além de caminhar na direção de se tornar condição da realização mais veloz dos ciclos dos diversos capitais.

É neste sentido que surgem os novos espaços e os novos produtos imobiliários na metrópole, entretanto, ambos não são produzidos na totalidade do tecido urbano metropolitano, pois seguem uma lógica de produção segundo estratégias de valorização que selecionam/hierarquizam "pedaços" da cidade para concentrar investimentos, revelando a seletividade espacial dos capitais, que imprimem na paisagem sua lógica, produzindo a hierarquização dos lugares.

O espaço atualmente possui como um de seus atributos o seu consumo produtivo. É dizer que a produção do espaço faz parte das novas estratégias de acumulação de frações de capital articulando vários setores da economia. Damos destaque em nosso trabalho de pesquisa à articulação entre o capital financeiro (de grandes, médios e pequenos investidores), o capital industrial, principalmente a indústria da construção civil e as frações de capitais que compõem o setor imobiliário.

Entendemos que a ponta financeira do processo bem como a estruturação dos fundos de investimento imobiliário e das aberturas de capital realizadas pelas empresas empreendedoras imobiliárias traz no processo de seu desenvolvimento contradições, mas este processo como um todo se encontra numa esfera mais abstrata, ligada ao lado imaterial do processo que se realiza plenamente a partir da produção do espaço urbano. E é neste momento, que passamos a considerar a produção do espaço urbano que alcançamos as contradições do espaço. As contradições do espaço se referem às contradições da sociedade expressas no processo de produção do espaço - contradições

\footnotetext{
${ }^{7}$ Tradução do autor.
} 
que marcam a dimensão espacial das atividades dos homens sob o capitalismo. Este movimento do pensamento sobre a realidade objetiva é importante quando nos damos conta de um problema: em que medida o próprio espaço, que é condição e meio para o processo, colocaria barreira para esse processo de financeirização do imobiliário e do capital financeiro se realizando através da produção do espaço? Esta questão possui uma dimensão teórica e prática. Teórica porque ela traz a negatividade do processo e prática porque o próprio espaço elemento central para que o processo aqui em evidência se realize, se torna barreira, limite a ser superado. Também nos encontramos diante de uma contradição do espaço. Como o espaço se torna barreira para a sua própria produção? A partir do pressuposto de que o espaço se torna mercadoria é que podemos iniciar uma reflexão que não se quer pronta e acabada. Quando pensamos no mercado de edifícios comerciais de alto padrão que necessitam da centralidade econômica e política dada pela expansão do eixo econômico, financeiro e de serviços mais avançados nos encontramos diante da raridade do espaço, isto é, como o setor de serviços mais sofisticados só pode se realizar neste fragmento específico da cidade de São Paulo há cada vez mais um número menor de terrenos disponíveis para a construção desses empreendimentos; portanto o espaço se torna raro, além de valioso. Refletindo a respeito da produção imobiliária residencial, observamos que a aquisição de terrenos passa a ser fundamental, mas não no sentido de realizar um grande estoque, mas sim no sentido de aplicar o capital em futuras incorporações. Como a lógica do setor imobiliário residencial é outra lógica em comparação ao setor imobiliário voltado aos edifícios comerciais, os terrenos podem ser adquiridos em vários lugares da metrópole, entretanto não em qualquer lugar. Essa diferença entre o residencial e edifício de escritório vai revelar a dimensão do espaço geográfico como localização, já evidenciando elementos limites ao processo.

Mas o espaço geográfico, como sabemos, é produto de relações sociais e aqui alcançamos o nível de sua produção e reprodução articulada à totalidade do modo de produção capitalista, procurando compreender os conteúdos do processo. Este, processo aqui em questão, pode ser entendido num contexto de reprodução crítica do capital; como nos mostra Arrighi em “O longo século XX”, o momento de financeirização da economia é um momento de crise. Entretanto é importante salientar que o momento de acumulação que vivemos, considerando o plano da reprodução capitalista geral, pode estar em crise, mas estes capitais individuais não estão, pois conseguem se valorizar e produzir acumulação. Entretanto, a produção do espaço sob a égide capitalista revela 
contradições cada vez mais profundas a serem superadas que podem pôr esses capitais individuais em crise. Acredito que esse movimento contraditório da produção do espaço como condição e meio e ao mesmo tempo barreira a ser superada complementa nossa análise e precisa ser mais bem explorado.

O espaço pode ser compreendido e analisado de diversas formas. Um caminho possível é o realizado por Lefebvre ${ }^{8}$ que parte de um entendimento de uma ciência do espaço, alcançando a produção do espaço como problemática geral, apontando para o fato de que no capitalismo há contradições do espaço. Tal problemática nos coloca diante de diversas questões que têm como ponto de partida a espacialidade. Assim, constrói um raciocínio que tem como idéia central sobre a questão espacial de que não se trata de uma ciência do espaço, mas do conhecimento de sua produção no plano da prática social (como teoria e prática; saber e ação), imersa numa realidade que é urbana, no sentido da constituição de uma sociedade urbana. Escreve o Autor:

A problemática do espaço vivido é um aspecto importante e, talvez, essencial de um conhecimento da realidade urbana. Vista sob este prisma, a problemática do espaço está vinculada à teoria do urbano e a sua ciência, e, consequentemente, a uma problemática ainda mais ampla, a da sociedade global. ... (Lefebvre, 1976:27).

Ao nos debruçarmos sobre o estudo do espaço é necessário estarmos atento para as dimensões do espaço. O espaço mental dos matemáticos e dos metafísicos, da lógica revela uma dimensão abstrata do espaço; o espaço possui também uma dimensão física a partir da qual análise caminha na direção do que pode ser encontrado no espaço, isto é, os objetos, as coisas que o espaço contem, e a dimensão social - "real” - revelaria a produção social do humano. Entendemos aqui que essas dimensões do espaço compõem uma unidade e que dependendo da análise que se faz a partir do entendimento que se tem da realidade aproxima-se mais de uma dimensão do que de outra, não levando em consideração as outras dimensões.

Como nomear a separação que mantém distante, um dos outros, os diversos espaços: físico, mental e social? Distorção? Diferença?Quebra? O nome

\footnotetext{
${ }^{8}$ Este caminho pode ser entendido como o movimento do primeiro capítulo do livro "Espacio y Política. El derecho a la ciudad II” e em parte do primeiro capítulo do livro "La production de l'espace”.
} 
importa pouco. O que conta é a distância que separa o espaço "ideal", ressaltando categorias mentais (lógico-matemáticas) do espaço "real”, aquele da prática social. Portanto, cada um implica, põe e supõe o outro. (Lefebvre, $2000: 21)^{9}$.

A união entre os diferentes termos, espaço físico, mental e social, deve ser premissa para a compreensão de uma teoria unitária do espaço e deve ser superado o abismo escavado entre esses termos, procurando redefinir o que é unitário.

A busca de uma teoria unitária não impede em nada, ao contrário, os conflitos no interior do conhecimento, as controvérsias e os problemas. Mesmo na física e nas matemáticas! Até na ciência que os filósofos crêem 'pura' porque eles a purificam de seus momentos dialéticos, há movimentos conflituais. (Lefebvre, 2000:20) $)^{10}$.

Ainda expõe o autor:

... O projeto que se esboça aqui não tem por fim produzir um discurso sobre o espaço, mas de expor a produção do espaço ela mesma, reunindo diversos espaços e as modalidades de sua gênese em uma teoria.

Teoria da produção do espaço, que ultrapasse a pergunta “o que é o espaço?” e se preocupe com um conhecimento da produção espaço.

Do ponto de vista da dimensão mental do espaço, estamos no plano do espaço concebido. Pensado como forma pura, livre de tensões e conflitos. Enquanto espaço concebido como forma pura e coesa não há relação com os conteúdos práticos sensíveis e materiais do espaço. Trata-se de um espaço sem vida, sem memória, entendido de forma racional. Segundo Lefebvre (1976:29) esse entendimento

... implica a liquidação do tempo histórico assim como o tempo vivido ... Comporta igualmente uma tendência para o cientificismo abstrato, para o

\footnotetext{
${ }^{9}$ Tradução do autor.

10 Tradução do autor.
} 
saber "absoluto" constituído por um inventário do passado e inserido no espaço atual. $^{11}$

Neste raciocínio, o mental e o social coincidem. Como desdobramento dessa primeira acepção, o espaço pode ser tomado como uma mediação, um instrumento, um meio entre o entendimento anterior (forma pura) e a próxima possibilidade de compreensão (dimensão física). O espaço passa a ser manipulado intencionalmente como um instrumento político, passa a estar na mão de um poder (Estado, burguesia, ou grupos que representam a sociedade global). Passa a ser entendido como um meio de produção e um meio de controle. Neste caso, a representação do espaço estaria a favor de uma estratégia, ao mesmo tempo abstrata e concreta, pensada e projetada no espaço. Encontramo-nos diante das relações de produção, num primeiro momento o da reprodução dos meios de produção que atinge como já apontava Marx no "Capítulo VI inédito de O Capital” a reprodução das relações de produção ultrapassando a estrita reprodução dos meios de produção. ${ }^{12}$ A reprodução das relações de produção se dá através de novas produções: o espaço, o urbano e o cotidiano ${ }^{13}$. É a partir deste entendimento que temos que ultrapassar a dimensão funcional e instrumental do espaço, compreendê-lo em sua dimensão mental, física e social, redefinidas em uma unidade em que elas não se coincidem.

O espaço físico contém a idéia de que o espaço social é um produto da sociedade, mas se preocupa com a localização dos objetos no espaço, como se o espaço fosse "o ponto de reunião dos objetos produzidos, o conjunto das coisas que o ocupam e de seus subconjuntos, efetuado, objetivado e, portanto 'funcional'." (Lefebvre, 1976:30). ${ }^{14}$ O espaço aparece como produto do trabalho e da divisão do trabalho. É importante frisar que esta possibilidade de compreensão já traz em si o entendimento de

\footnotetext{
${ }^{11}$ Tradução do autor.

12 Afirma Marx: "Vimos que a produção capitalista é produção de mais-valia e, nessa qualidade (na acumulação), é ao mesmo tempo produção de capital e reprodução da totalidade da relação capitalista numa escala cada vez mais extensa (alargada)...”. Karl Marx, Capítulo VI Inédito de O Capital. Resultados do processo de produção imediata. São Paulo, Editora Moraes, s/data. p. 139.

${ }^{13}$ Faz-se necessário completar a noção de reprodução das relações de produção revelando que esta noção articula três momentos fundamentais. "A- manutenção quanto ao essencial das relações sociais (de produção e de propriedade) no decurso de um crescimento das forças produtivas, vulgarmente chamado de crescimento econômico; B- regressões, degradações, transgressões (nomeadamente ao nível dito 'cultural', mas também na relação de família e amizade, na vida sócio-econômica dos grupos parciais); Cprodução de novas relações (no seio dos grupos parciais: a juventude, as mulheres, os 'trabalhadores' mas também naquilo que o processo reprodutivo utiliza, a saber: o cotidiano, o urbano e o espaço)." (Lefebvre, 1973:14).

${ }^{14}$ Tradução do autor.
} 
que o espaço social é um produto da sociedade. Entretanto podemos afirmar que ainda estamos no plano da organização do espaço. Com relação ao desenvolvimento do raciocínio aqui empreendido, é importante destacar que há no pensamento geográfico nos anos 1970/1980, do ponto de vista teórico metodológico, um movimento que caminha da organização do espaço em direção à produção do espaço. Era necessário superar $^{15}$ a idéia de espaço como localização dos fenômenos e palco da ação humana, superar as análises presas às descrições e também acrescentar à idéia central da relação homem-natureza, que o homem transforma a natureza transformando a sua própria, ou seja, essa transformação / ação deve aparecer como produto humano e assim o homem surge como sujeito e não mais um objeto / elemento das relações sociais. Assim, já apontamos aqui a próxima dimensão do espaço, que o tem como produto concreto inserido no movimento das relações sociais historicamente determinadas.

A dimensão social do espaço parte da idéia de que o espaço social é um produto social. Nesse sentido, o espaço

estaria essencialmente vinculado com a reprodução das relações (sociais) de produção. ... Para compreendê-la, se de tomar como referência não a produção no sentido restringido dos economistas - isto é, o processo da produção das coisas e de seu consumo -, mas a reprodução das relações de produção. Nesta ampla acepção, o espaço da produção implicaria portanto, $e$ encerraria em seu seio a finalidade geral , a orientação comum a todas as atividades dentro da sociedade neocapitalista. O espaço constituiria, pois, uma espécie de esquema em um sentido dinâmico que seria comum às atividades diversas, aos trabalhos divididos, à cotidianeidade, às artes, aos espaços criado pelos arquitetos e urbanistas. Viria a ser uma relação e um sustentáculo de incoerências na dissociação, de inclusão na separação. (Lefebvre, 1976:34) ${ }^{16}$.

O Autor ao trazer para análise o desdobramento da noção de reprodução das relações de produção aponta o papel central dos conteúdos especificamente capitalistas presentes e determinantes das relações sociais que se realizam na totalidade do espaço.

O pensamento sobre o espaço avança e vai significar não um dado a priori, uma forma pura, neutra, transparente, mas conforme Lefebvre (1976:40),

\footnotetext{
${ }^{15}$ Superação no sentido de conservar o que está sendo superado.

${ }^{16}$ Tradução do autor.
} 
se vê no espaço o desdobramento de uma atividade social. Se estabelece, pois, uma distinção entre o espaço social e o espaço geométrico, isto é mental...

Então observamos um movimento que vai do produto à produção; do espaço como um objeto ou soma de objetos para a produção do espaço como pressuposto e produto de toda a produção e de todo o intercâmbio.

Este espaço seria abstrato? Sim, mas ele é também "real”, como a mercadoria e o dinheiro, estas abstrações concretas. Seria concreto? Sim, mas não da mesma maneira que um objeto, um produto qualquer. Ele é instrumental? Certamente, mas como o conhecimento, ele demanda uma instrumentalidade. Se reduziria a uma projeção - a uma objetivação de um saber? Sim e não: o saber objetivado num produto não coincide mais com o conhecimento teórico. O espaço contém relações sociais. ... (Lefebvre, 2000:35-36) ${ }^{17}$.

Porém, a produção do espaço sob o modo de produção capitalista, nos coloca diante das contradições do espaço. Desta forma, temos que passar das contradições no espaço para as contradições do espaço.

As contradições no espaço referem-se às diferentes formas espaciais e suas funções, ao uso diferenciado que se faz do espaço e a própria (re)produção espacial que se dá de modo desigual e contraditório, o que nos faz pensar nos conflitos e tensões entre os interesses de grupos sociais distintos. As contradições no espaço, observadas e analisadas a partir das formas da paisagem, nos mostram os diferentes interesses pelo uso do espaço e os diferentes sujeitos que participam das relações e práticas sócio-espaciais. ${ }^{18}$

É tendendo a uma lógica, a uma racionalidade, a um sistema coerente que não é interno a produção do espaço, mas é o que se busca, é que observamos as contradições do espaço, as quais segundo Lefebvre são produto do conteúdo prático e social e, mais

\footnotetext{
17 Tradução do autor.

${ }^{18}$ Idéia desenvolvida pelo autor e está presente no Relatório de Pesquisa de bolsa de Iniciação Científica entregue ao CNPq em 2003.
} 
especificamente, do conteúdo capitalista. A reprodução das relações de produção ao se estender e tomar o desenvolvimento da sociedade em todos os níveis procura instaurar uma lógica, ou seja, tende para ela, na busca de um sistema coeso e coerente, no qual as contradições seriam dissimuladas, escondidas. Entretanto há um movimento desigual no desenvolvimento do capitalismo que faz com que as contradições emirjam e é neste momento que observamos que a lógica e o sistema que se busca é posto diante daquilo que os nega.

Foi através da pesquisa que realizamos sobre a constituição de um mercado imobiliário e sua relação como setor financeiro da economia num fragmento da metrópole paulistana que nos levou a construir esse caminho de raciocínio. Ao considerarmos a importância do processo de produção do espaço para desvendar um momento da urbanização em um fragmento da metrópole, é que observamos os limites postos à reprodução do capital através da produção do espaço. Empreendemos o raciocínio acima no sentido de construir uma problemática a cerca da produção do espaço e dar solidez teórica ao movimento de nosso trabalho de pesquisa que agora parte para considerações sobre a produção capitalista do espaço. Mas antes reiteramos que o caminho da análise é partir das considerações sobre entendimentos do espaço para se alcançar a produção do espaço e de suas contradições e aí alcançar a geografia, o espaço geográfico, como produto social produzido socialmente por meio do trabalho humano, entendido enquanto atividade do homem. Para Carlos (1994:33), “o espaço geográfico não é humano porque o homem o habita, mas antes de tudo porque é produto, condição e meio de toda atividade humana.” Essa idéia deve ser entendida no movimento da totalidade da reprodução social, procurando superar análises que se debruçam sobre fragmentos do espaço no arcabouço de ciências parcelares. Ou seja, trata-se de uma análise geográfica do espaço, mas num outro patamar, aquele que põe a Geografia no movimento do mundo.

O desenvolvimento do capitalismo e a realização do capital possuem uma qualidade interna que podemos dizer que se trata de uma reprodução crítica. Este raciocínio está atrelado à idéia de que o processo de realização do capital traz como imanente sua negatividade (a negatividade do capital)- a dimensão da crise. A diferença neste raciocínio é o de que não se trata de uma simples negatividade. Mas como escreve Grespan (1999:27), se trata de uma negatividade inerente, interna aos "processos que o capital realiza como manifestação de uma contradição constitutiva do capital”. Não se trata de oposição. No processo de sua realização o capital ao conter em si a dimensão da 
crise enquanto negatividade também expressa o momento de crise enquanto "crítica" que o próprio capital expõe ao seu processo de realização. Este momento é composto pela exposição de suas contradições num movimento de reposição, superação e o surgimento de novas contradições ${ }^{19}$. Assim escreve Grespan:

....apreendida como expressão da negatividade imanente ao capital, a crise está na base da crítica ao capitalismo, conforme um significado especificamente marxiano de "crítica": não se trata de uma reflexão exterior que aponta os limites desse sistema, e sim dos limites alcançados por ele mesmo com o desenvolvimento de suas potencialidades e com a exposição de suas contradições fundamentais nos processos que ele realiza. (Grespan, 1999:28).

Entretanto ao aceitarmos o raciocínio de que a crise é imanente ao capital e ao desenvolvimento do capitalismo temos que ter em mente que neste debate existe uma discussão sobre o conteúdo do conceito de crise e sua associação à crítica. Assinala Grespan (1999:30):

...se algum conteúdo dele [do conceito de crise] for considerado necessário, pode-se prever que o capitalismo fatalmente chegará a um colapso ou se todos os conteúdos forem só possíveis, que este sistema conseguirá controlar os impactos de suas crises, mantendo-se indefinidamente.

Então seria necessário discutir o processo de realização do capital e expor os momentos críticos de sua realização, que indica uma tendência ou outra. “Ao mesmo tempo em que o capital tende a realizar sua negatividade ele tende, também, a se por como sujeito” (Cruz, 2006:43). Sobre isso afirma Grespan (1999:270-271) ${ }^{20}$ :

Cindido em seu interior por sua contradição essencial, o capital jamais realiza as suas tendências expansivas, não chega a constituir permanentemente sua efetividade em sentido pleno. Bem, como por outro lado, ele também nunca realiza definitivamente sua tendência a crise, na forma de um colapso inevitável ou de uma progressiva estagnação até um estado de desvalorização crônica e insuperável. Devido a esta cisão, o capital exterioriza

\footnotetext{
${ }^{19}$ Aufhebung hegeliana: superação que conserva o que foi superado.

${ }^{20}$ Citado por Cruz 2006, p. 43.
} 
necessariamente o seu interior - cumprindo em parte a exigência da "efetividade” hegeliana - mas um interior cujo conteúdo é duplo e antagônico.

Em seu texto Grespan chama atenção para o significado marxiano de 'crítica', e afirma existir uma relação entre crise e crítica, fundamental para a compreensão desses conceitos no pensamento de Marx. Cruz (2006) se debruça sobre esta questão e em um capítulo de seu trabalho que te como título: "O capital como movimento: separação, crítica e crise” escreve, apoiado em Koselleck e Habermas ${ }^{21}$, que

...crítica e crise estão fundamentalmente ligadas, já que se há uma crítica subjetiva ela se refere a uma crise objetiva. Esta crítica subjetiva não é, portanto, indeterminada. Ao contrário ela só existe com um impulso por superar a crise objetiva. Dessa forma a relação entre crítica e crise nos remete a uma situação crítica, entendida aqui como condição de cisão que exige um movimento de superação. (Cruz, 2006:41).

É interessante observar como a crítica aparece em citação anterior de Grespan como crítica no sentido marxiano, aquela que o próprio capital realiza durante seu processo de realização, apontando um momento de crise que é inerente ao capital e não uma negatividade geral (porém contendo dentro de si a possibilidade enquanto tendência de uma não acumulação, de uma desvalorização). Daí, os termos crítica subjetiva e crise objetiva.

A idéia de separação deve ser compreendida através do processo de cisão interna que o capital coloca ao seu próprio movimento de realização. Alguns movimentos de separação são fundamentais para a realização do capital. A separação entre a produção e a realização da riqueza: aqui se coloca a valorização do valor como necessidade - o valor como riqueza abstrata, produzido somente na produção material capitalista. As separações ligadas aos processos de acumulação primitiva (a separação entre força de trabalho e meios de produção, por exemplo). É importante também acrescentar a separação entre o político e o econômico (reprodução do poder político do Estado e reprodução econômica do capital). Conforme Cruz (2006:20) “o Estado está ligado ao

\footnotetext{
${ }^{21}$ Grespan ao se referir a importância fundamental da relação entre os conceitos de crise e crítica indica uma bibliografia sobre o tema composta por três textos de autores diferentes. Para sua dissertação de mestrado Cruz estuda dois desses três textos, sendo eles: Crítica e crise de Reinhart Koselleck e "Entre Ciência e Filosofia: o Marxismo como Crítica". In: Teoria y Praxis: Estudios de Filosofia Social de Jügen Habermas.
} 
capital na gênese de ambos por meio da separação entre o político e o econômico.” 22 Ainda sobre a idéia de separação podemos recordar o capítulo de Marx em O Capital, “A fórmula trinitária do capital”. Os três termos terra, trabalho e capital estão separados no seio de uma unidade. Os três termos possuem a tendência a parecerem fontes distintas da riqueza e da produção, quando é justamente pela sua união que produzem tal riqueza. A terra, o trabalho e capital em sua separação na união nas mãos da burguesia é uma característica fundamental do desenvolvimento do capitalismo.

O objetivo desta discussão é o de trazer para o debate a idéia da existência de uma negatividade do capital nos termos acima expostos, e como a realização do capital por meio do processo de produção do espaço urbano nos coloca diante dos limites do capital e também dos limites da produção do espaço sob o capitalismo.

Refletindo sobre as contradições resolvidas e não resolvidas no movimento de desenvolvimento do modo de produção capitalista, Lefebvre (1973:21) afirma que o capitalismo conseguiu atenuar sem resolver suas contradições internas, o que possibilitou a superação de suas crises e o seu crescimento no século XX. Seguindo este raciocínio o Autor se coloca a questão de como o capitalismo se desenvolve superando essas crises e sua resposta é: “ocupando o espaço, produzindo um espaço”. E na mesma obra complementa a idéia afirmando que

Não é apenas toda a sociedade que se torna o lugar da reprodução (das relações de produção e não apenas dos meios de produção): é todo o espaço. Ocupado pelo necapitalismo, setorizado reduzido a um meio homogêneo e, contudo, fragmentado, reduzido à pedaços (só se vendem pedaços de espaço às “clientelas”), o espaço transforma-se nos paços do poder. (Lefebvre, 1973:95).

O movimento exposto acima através das idéias de Lefebvre é que nos fez pensar na idéia central deste trabalho: o espaço como condição para a reprodução do capital tendo como estratégia a produção do espaço. Um momento importante para discussão da produção do espaço sob o capitalismo é o espaço tornado mercadoria (a existência da propriedade privada da terra) imerso nos circuitos de valorização do capital.

\footnotetext{
22 Essas idéias serão retomadas na discussão sobre o Estado e espaço na produção da cidade, especificamente o eixo empresarial da metrópole.
} 
O espaço é condição geral para reprodução da sociedade. Neste plano, ou seja, do uso e da apropriação, guarda a dimensão da realização da vida do homem. Entretanto, inserido no movimento de reprodução geral da sociedade, isto é, imerso no processo de desenvolvimento do modo de produção capitalista, o espaço tornado mercadoria, passa a ser consumido produtivamente. Como uma mercadoria, passa a possuir uma dupla determinação, valor de uso e valor de troca. No modo de produção capitalista, observamos a preponderância do valor de troca sobre o valor de uso e a troca como relação fundamental para o desenvolvimento do modo de produção. Assim, é urgente que se realize o valor de troca. A mediação para esse processo é o mercado no contexto de uma relação de troca tipicamente capitalista, que impõe a valorização. Estamos diante do processo de valorização do espaço que ocorre através da mercantilização do espaço.

Para que esse movimento ocorra, é necessária a hegemonia de uma classe (contraditoriamente articulada ao Estado). Uma idéia de Harvey em “A Justiça Social e a Cidade” citada por Botelho (2005:09) traz a dimensão de uns dos raciocínios expostos na Introdução deste trabalho.

Para o entendimento da produção do espaço, sobretudo do espaço urbano, devemos levar em consideração, então, o monopólio de uma classe sobre o espaço - a alta burguesia, no caso do capitalismo -, o que exclui principalmente os pobres da propriedade fundiária (Harvey, 1980:146). Isto porque, a classe que detém a maior parte dos recursos, pode através do dinheiro, ocupar, modelar, fragmentar o espaço da forma que melhor lhe convém. A maximização dos valores de troca produz benefícios desproporcionais para alguns grupos e diminui as oportunidades para outros (Idem:150).

Ao considerarmos o espaço como elemento central na reprodução das relações de produção, temos conhecimento de que, como afirmamos anteriormente, a produção do espaço pode ser vista como um processo implicado na reprodução dos capitais. De forma geral, estamos diante da migração de capitais entre setores da economia que serão aplicados na produção do espaço em dois planos ${ }^{23}$. Primeiramente na construção de obras de infra-estrutura para a circulação de capitais e mercadorias, o que Harvey

\footnotetext{
${ }^{23}$ É a partir daqui que surge a idéia de ambiente construído e a problemática do tempo de rotação e realização dos capitais aí investidos, bem como a possibilidade do espaço aparecer como meio de produção e gerar mais-valia.
} 
chama de "ajuste espacial” e o investimento no setor imobiliário, preocupação que move nossa investigação.

Ao tratar da temática “ajuste espacial”, Harvey ${ }^{24}$ aponta uma tendência interna dos nexos de realização do capitalismo- a superacumulação; o que vai exigir, segundo o autor, uma re-ordenação espacial do capitalismo. Essa superacumulação, produto da tendência expansionista do capitalismo, presente nos nexos de reprodução deste modo de produção, se caracteriza por um momento em que há uma soma de capitais a serem investidos e que não encontra essa possibilidade nos circuitos de valorização do capital, não podendo gerar lucratividade. Daí o risco à desvalorização, pois o capital, como escreveu Marx, é circulante e necessita de participar dos circuitos de valorização do valor para se realizar enquanto capital. A desvalorização do capital aponta a não existência dele enquanto tal. O ajuste espacial se trata então de uma aplicação desses investimentos de outras formas e em outros lugares, tais como na produção do espaço; como escrevemos acima, na produção de infra-estruturas no espaço. Este mecanismo pode amenizar ou atrasar os problemas relativos à tendência a sobreacumulação. Entretanto, quando o investimento é realizado em grandes obras de infra-estrutura o capital se imobiliza em capital fixado ao solo, sendo mais demorado o tempo de rotação dos capitais aí investidos. Mas frente ao problema da superacumulação e da desvalorização este capital pode ser assim aplicado mesmo correndo-se o riso dele não se realizar como valor. Este movimento se articula à idéia da crise, já exposta. Assim afirma Harvey (2005:156):

... a teoria da superacumulação e da desvalorização revela o intenso poder destrutivo existente sob a fachada do capitalismo relativa ao progresso tecnológico e à racionalidade do mercado. No decurso da crise, grandes quantidades de capital são desvalorizadas e destruídas, os trabalhadores e sua força de trabalho sofrem um destino semelhante, e os capitalistas canibalizam e liquidam uns aos outros, na "guerra de todos contra todos", o derradeiro sinal do modo de produção capitalista.

Os investimentos no mercado imobiliário também caminham na direção de fuga dessa desvalorização. Porém, a dinâmica deste mercado, seus investidores e as

\footnotetext{
${ }^{24}$ Harvey (1984, 2004 e 2005)
} 
estratégias de quem o dirige revelam outra relação entre a imobilidade do imobiliário e a mobilidade do capital e sua importância para a economia capitalista atual.

Lefebvre (1999:146-147) aponta a migração de capitais acumulado no setor produtivo industrial para o setor imobiliário e aponta que "o papel do imobiliário ... ainda é mal conhecido e mal situado nos mecanismos gerais da economia capitalista”. Escreve o Autor:

...O imobiliário como se diz, desempenha o papel de um segundo setor, de circuito paralelo ao da produção industrial voltada para o mercado dos “bens" não-duráveis ou menos duráveis que os "imóveis”. Esse segundo setor absorve os choques. Em caso de depressão para ele afluem os capitais. Eles começam com lucros fabulosos, mas logo se enterram. Nesse setor, os efeitos “multiplicadores” são débeis: poucas atividades são induzidas. O capital imobiliza-se no imobiliário. A economia geral (dita nacional) logo sofre com isso. Contudo, o papel desse setor não deixa de crescer. Na medida que o circuito principal, o da produção corrente dos bens "mobiliários", arrefece seu impulso, os capitais serão investidos no segundo setor, o imobiliário. Pode até acontecer que a especulação fundiária se transforme na fonte principal, o lugar quase que exclusivo de "formação do capital", isto é, de realização da mais-valia. Enquanto a parte da mais-valia global formada e realizada na indústria decresce, aumenta a parte da mais-valia formada e realizada na especulação e pela construção imobiliária. O segundo suplanta o principal. De contingente, torna-se essencial... ${ }^{25}$

Acreditamos que as idéias de Lefebvre expostas nesse fragmento ${ }^{26}$, dão caminhos importantes para as considerações que pretendemos traçar neste trabalho a respeito do setor imobiliário. O movimento destacado sobre a migração de capitais é muito importante, mas agora acontecendo num outro nível- o da produção do espaço como condição para a reprodução do capital.

No processo de financeirização da economia é importante destacar aqui dois momentos: os fluxos de capitais dos setores produtivos para o setor financeiro e a aplicação desses capitais no setor no imobiliário. Kurz (2003) escreve um texto afirmando que os investimentos financeiros no imobiliário seriam uma segunda bolha

\footnotetext{
${ }^{25}$ Grifos meus.

${ }^{26}$ Este fragmento do Livro a Revolução Urbana, escrito na década de 70, foi inspirador para a construção de nossa problemática de pesquisa na elaboração do projeto em 2004.
} 
financeira, porém a nomeia de financeira imobiliária que tem por papel adiar a crise. Com a financeirização da economia a migração de capitais para o setor imobiliário torna-se uma aposta, uma especulação, mas a partir deste processo quantias significativas de capital são investidos no setor imobiliário, como possibilidade de sua realização. $^{27}$

Segundo Carlos (2004:52),

O momento atual sinaliza, portanto, uma transformação no modo como o capital financeiro se realiza na metrópole atual; a passagem da aplicação do dinheiro acumulado do setor produtivo industrial ao setor imobiliário. Assim, a mercadoria-espaço mudou de sentido com a mudança da orientação das aplicações financeiras, que produz o espaço como "produto imobiliário”...

As idéias centrais do fragmento acima citado sobre o imobiliário como segundo setor da economia que absorve os choques do desenvolvimento do capitalismo é ponto de partida para o que pensamos ser o novo, o diferente no processo, pois há novos conteúdos de acordo com o momento da reprodução geral do capitalismo. O que este processo nos aponta é que o solo urbano não aparece mais somente como reserva de valor (principalmente em momentos de crise da indústria), mas cada vez mais como investimento possível de gerar de mais valor, implicado em estratégias que tornam a produção do espaço um setor produtivo, ou seja, a passa a ser condição da acumulação e o setor imobiliário ganha importância central, principalmente quando se concretizam estratégias que dão mobilidade potencial aos capitais. Os investidores financeiros (pessoas físicas, jurídicas, nacionais ou estrangeiros) apostam no imobiliário como possibilidade de realização de seus capitais. Este processo se desenvolve no movimento de generalização da forma mercadoria que põe o espaço enquanto tal, fazendo com que cada vez mais o espaço faça parte dos circuitos de valorização. O que aparece como novo neste processo é que a valorização do espaço e sua produção hoje se dão em uma nova dinâmica econômica: a realização do capital financeiro; a produção do espaço ganha cada vez mais importância no sentido de garantir a reprodução, no movimento das contradições no processo de realização do capital e das contradições do espaço produzido sob o capitalismo.

\footnotetext{
${ }^{27}$ É neste sentido que justificamos nossas escolhas pelos Fundos de Investimento Imobiliário e a abertura de capital na bolsa de valores por parte de empresas empreendedoras imobiliárias.
} 
Assim podemos afirmar que este processo não é linear e que inserido na reprodução geral da sociedade sob o capitalismo está propenso aos momentos críticos da realização do capital. Desta forma, não podemos entender essa migração de capital entre setores da economia, principalmente a relação entre o financeiro e o imobiliário sem levar em conta os “obstáculos à reprodução do capital no setor imobiliário”28 e a própria produção do espaço como barreira a sua realização.

A partir de nosso trabalho de investigação entendemos aqui como obstáculos a propriedade privada da terra, a valorização do solo urbano e a raridade do espaço. Botelho (2005:44), além da propriedade privada da terra, discute como obstáculos à reprodução do capital no setor imobiliário a necessidade de financiamento da produção e da venda do produto imobiliário (neste caso, mais especificamente no setor imobiliário residencial).

De acordo com Botelho (2005:44), a propriedade privada do solo urbano já é uma barreira à livre entrada de capitais no setor de construção. Como veremos mais adiante a propriedade privada do solo, elemento central para a reprodução capitalista torna-se impeditiva para a produção do espaço. Outro ponto abordado pelo autor é que o setor da construção tem que dispor de um volume considerável de recursos para adquirir terras para a produção imobiliária - o que vai limitar as opções de construção encarecendo o produto final, o que pode comprometer a demanda. Dessa forma, o financiamento da produção ${ }^{29}$ se torna um obstáculo, pois é preciso a existência de um capital autônomo que financie o processo de produção, cobrando juros do produtor. Tais juros são pagos por parte da mais-valia gerada no interior do processo de construção, aumentando o preço do produto final.

A valorização do espaço pode surgir como um limite no sentido de concentrar uma boa infra-estrutura e possuir maior preço fazendo com que a lucratividade dos empreendedores seja menor. Em relação à valorização do espaço e o preço do solo Carlos (1994:171) afirma que:

O processo de formação do preço da terra, como manifestação do valor das parcelas, leva em conta desde processos cíclicos da conjuntura nacional (que incluem a forma de manifestação de processos econômicos mundiais) até aspectos políticos e sociais específicos de determinado lugar. Todos esses

\footnotetext{
${ }^{28}$ Cf. Botelho 2005:44.

${ }^{29}$ O que vai demandar um sistema de crédito organizado.
} 
fatores vinculam-se ao processo de desenvolvimento urbano, que, ao se realizar, redefine a divisão espacial, e com isso o valor das parcelas. Este valor será determinado em função do conjunto ao qual pertencem, e é nesta inter-relação entre o todo e a parte que ocorre o processo de valorização real ou potencial de cada parcela do espaço.

Outro elemento importante como limite a produção do espaço e também limite à realização do capital no setor imobiliário é a existência da raridade do espaço que articula a existência da propriedade privada da terra e a valorização capitalista do espaço numa conjunção entre espaços construídos e de espaços “vazios” (ambos de propriedade de alguém). Escreve Lefebvre (1976:39):

... o alto preço alcançados pelos espaços ocupados e a escassez, cada dia maior, dos espaços ainda por ocupar constitui um fenômeno recente cujas conseqüências são cada vez mais graves. ${ }^{30}$

É importante observar que a idéia de localização ${ }^{31}$ está presente no raciocínio empreendido a respeito da raridade do espaço. Articulado a idéia de localização está a idéia de caro, uma associação ao preço, expressão do valor do solo urbano. Sobre a raridade do espaço escreve Carlos (2001:22):

No momento atual do processo histórico, a reprodução espacial, com a generalização da urbanização, produz uma nova contradição: aquela que se refere à diferença entre a antiga possibilidade de ocupar áreas como lugares de expansão da mancha urbana (com o parcelamento de antigas chácaras ou fazendas, caso de muitos bairros na metrópole) e sua presente impossibilidade diante da escassez. Nesse processo, o espaço, na condição de valor, entra no circuito da troca geral da sociedade (produção / repartição / distribuição), fazendo parte da produção da riqueza e constituindo raridade. ... o espaço produzido socialmente - e tornado mercadoria no processo histórico - é apropriado privativamente, criando limites a sua própria reprodução (em função da produção de sua própria escassez). Nesse momento o espaço produto da reprodução da sociedade, entra em contradição com as necessidades do desenvolvimento do próprio capital. Isso significa que a

\footnotetext{
30 Tradução do autor.

${ }^{31}$ Trata-se de uma dimensão extremamente geográfica.
} 
“raridade” é produto do próprio processo de produção do espaço, ao mesmo que sua limitação.

Outra dificuldade enfrentada pelo mercado imobiliário, segundo Lefebvre (1976:102), é a luta contra lenta obsolescência dos produtos imobiliários e a lenta rotação do capital no setor imobiliário. Somente a construção constante de novos empreendimentos não é suficiente, esse processo, também segundo o Autor é a autodestruição dos espaços produzidos. Daí Botelho (2005:12) afirmar que é criado "um movimento constante de relocalização, destruição e reconstrução no e do espaço.”

No raciocínio empreendido no trabalho, estes obstáculos ou limites possuem uma centralidade essencial, principalmente no movimento do pensamento que construiu a exposição da pesquisa realizada. Trata-se de um momento no qual, definitivamente, entendemos a negatividade do capital inerente a sua realização e que também está presente no processo de produção capitalista do espaço, no sentido do espaço se tornar lugar da reprodução das relações de produção. Sob o capitalismo, a produção material do espaço também possui, no movimento de seu desenvolvimento, momentos de crises imanentes a esse processo, pois as contradições da sociedade dominada pelas relações capitalistas de produção são integrantes do processo de produção espacial imerso na reprodução geral da sociedade. O processo guarda em si uma cisão / separação fundamental: a produção material do espaço e o uso social deste espaço mediado pelo mercado de terras / mercado imobiliário e que ainda está permeado os interesses do Estado e do capital.

A partir disso, o mercado imobiliário desenvolvido nas condições específicas e expressando as contradições do modo de produção capitalista aparece como um mercado imobiliário crítico.

Foi a partir da análise de um fragmento da metrópole paulistana, o eixo empresarial que se expande do centro ao sudeste / sul de São Paulo, que as considerações de nosso trabalho de pesquisa foram tomando corpo. Os dois mapas a seguir representam respectivamente o sentido da expansão do eixo e as principais regiões de construção de edifícios de escritórios em São Paulo, de acordo com a Bolsa de Imóveis de São Paulo (BIESP) e as principais avenidas deste fragmento: Paulista, Brig. Faria Lima e Luiz Carlos Berrini (incluindo também a Marginal do rio Pinheiros).

Já muito debatido em diversas pesquisas acadêmicas, o eixo empresarial da cidade de São Paulo, possui características muito particulares no que diz respeito à 


\section{MAPA 1}

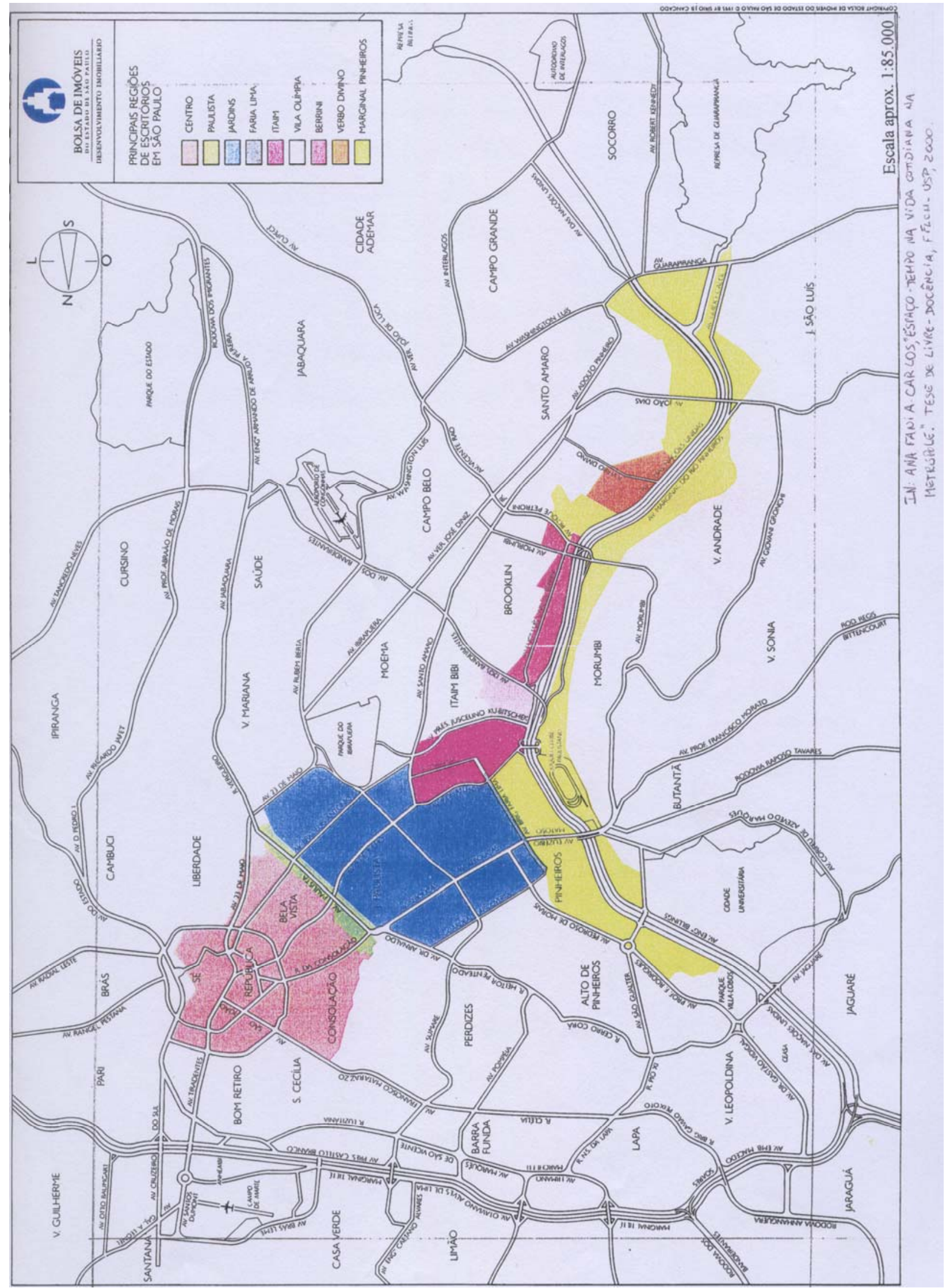


MAPA 2

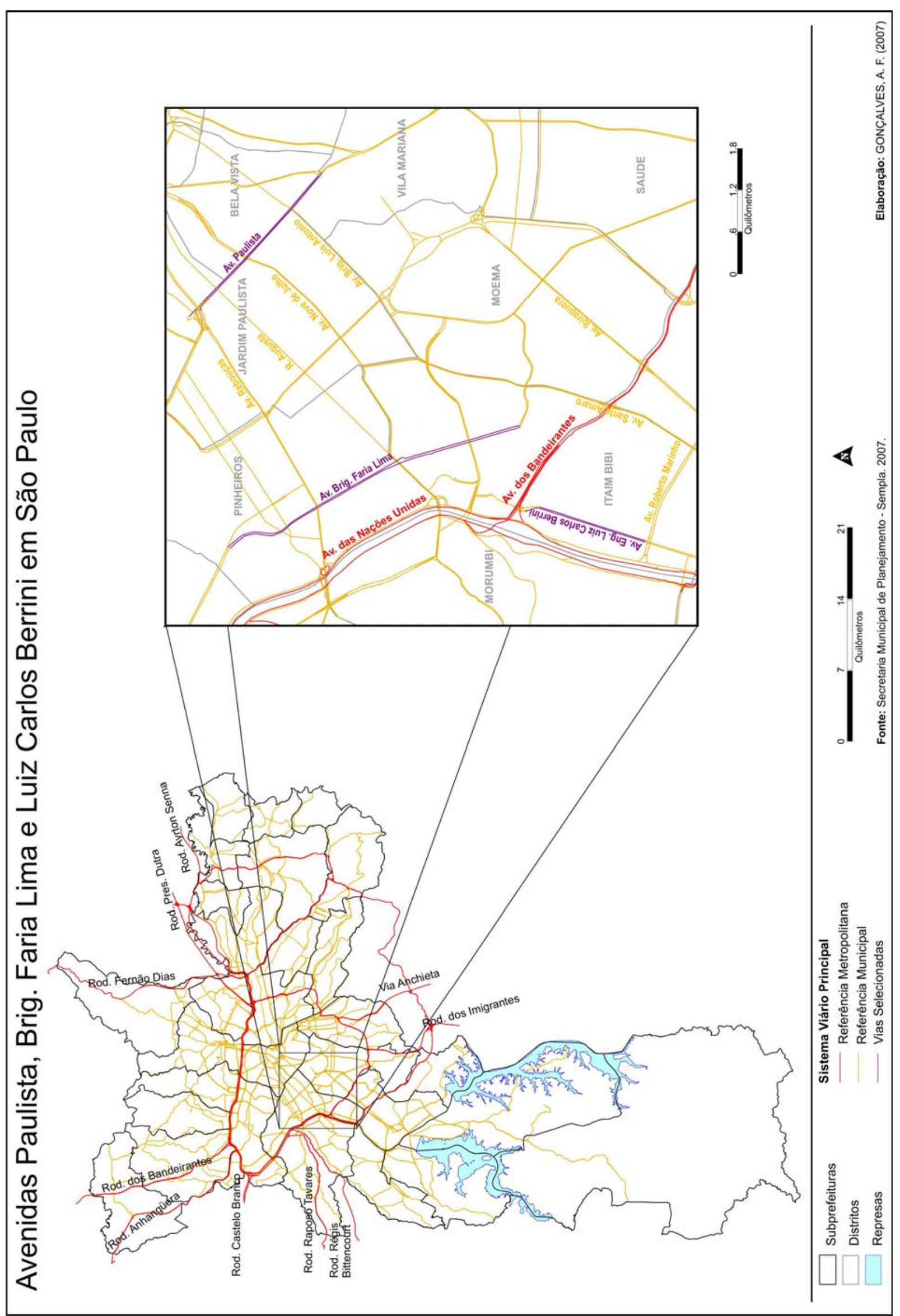


produção do espaço na metrópole. Como resultado da expansão do centro de São Paulo em direção ao sudoeste / sul, a constituição deste fragmento está articulada às transformações econômicas da metrópole e a inserção da produção do espaço urbano nos circuitos de reprodução do capital, sobretudo sua fração financeira ${ }^{32}$. Também como escreve Carlos (2001:94), “as transformações são acompanhadas por estratégias imobiliárias bem precisas, o que direciona os investimentos no espaço em um momento em que o imóvel deixa de ser hedge para virar investimento.” Num primeiro momento, essa expansão ocorre em direção à avenida Paulista nos anos 70, conformando esta região da metrópole como centro financeiro do país. É a partir deste momento que aprofundamos nossa análise do desenvolvimento deste fragmento em São Paulo, pois é quando estratégias de valorização do espaço empreendidas por um pequeno grupo de empresários se concretizam na Av. Berrini no final dos anos 70 e início dos anos 80. Além disso, os anos 70 caracterizam-se pelas medidas de desregulamentação financeira que foram sendo tomadas nos países centrais, atingindo o Brasil de forma mais premente na década de 1990, a partir da abertura do mercado interno aos capitais internacionais.

Nas últimas décadas, o desenvolvimento de constituição desse eixo contou com momentos diferentes e sujeitos sociais diferentes. As avenidas Berrini e Faria Lima (região onde se localizam os empreendimentos analisados neste trabalho) aparecem como produto da expansão do centro da cidade de São Paulo, que ao se expandir cria novas centralidades que vão compor o eixo aqui em questão. No movimento de integração de lugares específicos / estratégicos da metrópole ao eixo que se expande, cada uma dessas avenidas tiveram um processo peculiar e particular de valorização e de reintegração - integração aos espaços “novos” da metrópole, que culminou numa deterioração/degradação da vida dos moradores destes locais (os habitantes, em quase sua totalidade, foram expulsos desses lugares) e na produção de um lugar onde a forma dos edifícios de vidro e aço triunfam na paisagem, onde a prática sócio-espacial se transformou radicalmente. Assim, este processo não ocorre sem profundas transformações na morfologia da cidade, bem como no plano da prática sócio-espacial e da vida cotidiana. O plano da paisagem revela um fragmento da metrópole onde há uma

\footnotetext{
${ }^{32}$ A idéia de capital financeiro utilizada por nós é a Hilferding e Lênin apontada por Harvey (1984:316). $\mathrm{O}$ autor trabalha com dois conceitos de capital financeiro. O primeiro é o de um processo de circulação de capital a juros; o segundo de um bloco de poder institucionalizado dentro da burguesia. A idéia de bloco de poder institucionalizado dentro da burguesia é o que Hilferding entende por capital financeiro, u seja a união do capital industrial e bancário.
} 
alta concentração de investimentos em infra-estrutura e um "boom” de edifícios corporativos de escritórios e hotéis. Diferentemente da indústria que se localiza em diferentes áreas da metrópole, principalmente em suas franjas periféricas, o novo setor de serviços modernos só pode se localizar neste eixo de expansão da centralidade econômica de São Paulo, o que vai revelar diferentes estratégias e interesses que vão constituir o processo de reprodução do espaço neste fragmento da metrópole.

Existem duas explicações, que se complementam, para justificar a constituição desse eixo empresarial em São Paulo. O primeiro argumento é o de que a expansão do eixo empresarial de São Paulo ocorre no movimento de transformações da economia da metrópole articulada com as transformações da economia mundial. A formação de um mercado de imobiliário (de alto padrão que comporta altíssima tecnologia e investimentos milionários) voltado à construção de edifícios de escritórios que são construídos como investimento e serão alugados para grandes empresas corporativas, empresas prestadoras de serviços sofisticados de informática e telecomunicações num novo espaço profundamente transformado tanto no plano da morfologia espacial quanto no da social, revelando estratégias imobiliárias e de produção do espaço muito bem planejadas entre uma elite local e o Estado numa articulação com o mundial, é o segundo argumento.

O desenvolvimento de constituição deste eixo empresarial é marcado pela união contraditória entre o Estado e os capitalistas. Lefebvre, no tomo III da obra De l’Etat, afirma que o político e o econômico no modo de produção capitalista são separados, mas se realizam em uma separação na união. O Estado procura manter seus interesses através da reprodução do poder político e o econômico através da reprodução do capital. Entretanto nessas ações um depende do outro. O Estado oferece as condições contratuais, legais e de infra-estrutura para que os investimentos no espaço se realizem através da constituição deste eixo empresarial por meio de um mercado imobiliário (que funciona também sobre as regras e leis do Estado) ligado à elite paulistana, representante dos interesses do capital que procura colocar São Paulo no ritmo da globalização da economia. A elite econômica realiza seus capitais investindo no espaço e mostrando que o Estado oferece as condições para que São Paulo, como maior metrópole brasileira, se insira no movimento da mundialização. Tanto o Estado como os capitalistas realizam seus interesses reprodução do poder e realização do capital respectivamente. Sem esta relação não há possibilidade das tendências e virtualidades da reprodução das relações de produção se concretizarem nos lugares. 
Permitimo-nos aqui citar parte de um texto escrito por mim no ano de 2004 sobre a relação do Estado e os grupos privados presentes no processo de produção espacial no eixo empresarial de São Paulo. ${ }^{33}$

No caso específico do processo aqui em questão, o Estado surge com ações definidas quando realiza obras viárias de grandes proporções, como a Operação Urbana Água Espraiada, a Operação Urbana Faria Lima (obras que já estavam sendo esperadas desde a década de 70), a construção dos túneis Ayrton Senna, Tribunal de Justiça, Jânio Quadros e Sebastião Camargo (ambos sob o rio Pinheiros), com o discurso de melhoria do tráfego viário na cidade.

Outro momento importante, em que o Estado aparece de forma crucial, é no processo de desocupação da área ocupada pela favela Jardim Edith no ano de 1995 como parte da Operação Urbana Água Espraiada (hoje Av. Jornalista Roberto Marinho). No trabalho de Fix (2001), podemos entender como a iniciativa privada e o Estado (no caso a prefeitura) convergem seus interesses para a realização de um projeto que, relativo ao Estado aparece como uma obra viária necessária e para o grupo de empresários da região da Berrini, como uma possibilidade de valorização de seus empreendimentos já construídos e uma valorização futura que ocorreria na área. A remoção da favela traria mais investimentos e empresas para a região. O grupo de empresários tinha como principais articuladores Roberto Bratke da Bratke-Collet, O World Trade Center, incluindo o Shopping D\&D e o Hotel Meliá, a BIESP (Bolsa de Imóveis do Estado de São Paulo), Luís Eduardo Pinto Lima do Unibanco, Alcides Santos Diniz, representando a ASD Empreendimentos e o Centro Empresarial Nações Unidas. (Frúgoli Jr., 2000:206). Esse poll de empresários, nos dizeres de Frúgoli Jr. criou a "Associação de Promoção Habitacional”, que com a legitimidade da prefeitura, segundo Mariana Fix, seria responsável por construir no Jardim Educandário (nas imediações da Rodovia Raposo Tavares) um conjunto habitacional, onde parte das famílias removidas da região iriam morar se assumissem um financiamento. Outros mecanismos também foram usados pela prefeitura para "convencer" os moradores a deixarem a área, como o pagamento de passagem para que moradores migrantes voltassem para a terra natal ou oferecer pagamento de quantias superiores às estipuladas legalmente para a remoção.

\footnotetext{
33 Este trecho faz parte de nosso Trabalho de Graduação Individual (TGI), apresentado e defendido em maio de 2004 no Departamento de Geografia da FFLCH / USP.
} 
Sendo assim, observamos que os grupos privados da região constituem alianças políticas com o Estado a favor de seus interesses. Estamos aqui diante da dominação do espaço mediada pelo Estado, num processo em que o espaço se torna estratégico como possibilidade de reprodução do capital (plano da acumulação ampliada); como possibilidade de manutenção das relações sociais capitalistas; como possibilidade de manutenção das estratégias do Estado (gestão política do espaço), que só se realizam enquanto relações sociais que se concretizam no espaço, impondo uma prática social reveladora de processos contraditórios. Ou seja, é necessário compreender que o espaço está inserido nas relações de produção capitalistas, como força produtiva capaz de realizar a acumulação de capital por meio de sua produção. Nesse sentido, vivemos um momento em que, cada vez mais, a primazia do econômico, típica do modo de produção capitalista, é sustentada pelo Estado, enquanto mantenedor do laço social.

Desta forma, entendemos que o processo de produção do espaço na região de estudo, ocorre através de uma articulação entre o Estado e grupos privados, que pela mediação do mercado imobiliário se unem para a realização no espaço do poder econômico e da dominação política. É neste movimento que percebemos que o setor imobiliário torna-se fundamental para a acumulação. E nesta direção, aparece o entendimento da cidade moderna como lugar da realização do capital e de sua acumulação.

Enfim, a questão da circulação viária como problema fulcral da metrópole e o momento da constituição de uma tendência da supremacia do setor terciário na metrópole, evidenciando o surgimento de uma nova economia que necessita de um espaço novo e um lugar específico para se realizar, são condições para diretrizes que orientam / orientarão o processo de acumulação de capital, sua reprodução e sua realização através da produção do espaço da metrópole, revelando uma articulação entre o Estado e grupos ligados ao setor imobiliário. (Miele, 2004:29-31).

O caso Bratke, também muito discutido em São Paulo e estudado em diversos trabalhos sobre a metrópole, revela claramente como as suas estratégias de promotores imobiliários e urbanistas são típicas de um processo que guarda em si acordos políticos entre o capital e o Estado. ${ }^{34}$ A ação das empresas Braket-Collet S/C Ltda, Braco S/C

\footnotetext{
${ }^{34}$ No início, segundo o próprio Carlos Bratke, o Estado não tinha conhecimento do que ele e seus parentes estavam realizando na região. Entretanto, assim que suas estratégias de valorização da região da
} 
Ltda e F. Collet Ltda deixa evidente a força que um grupo de promotores / investidores do mercado imobiliário de escritórios possuem na produção do espaço em um fragmento da metrópole.

Torna-se muito importante na análise que empreendemos em nosso trabalho discutir a respeito desses sujeitos sociais que se unem contraditoriamente para realizar seus investimentos no espaço. Santos (1994) escreve que:

A análise de uma cidade (...) supõe também que os fatores estratégicos sejam levados em conta, o que permite identificar melhor o lugar real que tem cada agente ou grupo de agentes, cada ação ou grupo de ações, no processo de desenvolvimento urbano, a cada momento da história.

Nas análises mais recentes sobre todo esse processo de reestruturação espacial pelos quais as grandes cidades do mundo estão passando, esses processos são postos como necessários ao novo momento do capitalismo mundial, em especial à globalização. É desses pensamentos que surgem as idéias não críticas, ou muito pouco críticas de "planejamento estratégico”, do “empreendedorismo urbano” e “marketing urbano”. É necessário ser crítico a esses modelos internacionais de cidades. Porém, não podemos negar primeiro que a dimensão de uma nova economia pautada no seu processo de financeirização se realiza mundialmente e traz transformações no processo de produção da cidade, mas também não podemos deixar de, mais uma vez afirmar aqui que a reprodução geral da sociedade capitalista hoje se dá através do que Lefebvre chama de mundialidade do espaço e de uma sociedade urbana em constituição, em parte real e em parte virtual, se realiza também no plano da mundialidade. Mas, há uma articulação dos sujeitos sociais locais com grupos capitalistas internacionais que se articulam para a construção de espaços como esse do eixo empresarial de São Paulo.

Do ponto de vista do empreendedorismo temos agindo na cidade os seguintes sujeitos sociais, segundo Harvey (2005:230):

Berrini para construção de edifícios de escritórios se concretizam e aí se torna uma realidade para o mercado a relação do estado passa a mudar paulatinamente até chegarmos à Operação Água Espraiada e sua continuação hoje e na Operação Urbana Faria Lima e seu prosseguimento nos anos 2003/2004, com a construções dos túneis; o túnel no cruzamento das avenidas Brig. Faria Lima e Rebouças entre os bairros de Pinheiros e Jardins e o túnel no cruzamento entre as avenidas Brig. Faria Lima e Cidade Jardim entre os bairros Jardins e Itaim. 
Nas últimas décadas o empreendedorismo urbano se tornou importante tanto nacionalmente quanto internacionalmente. Por empreendedorismo urbano entendo o padrão de conduta na governança urbana que combina poderes estatais (local, metropolitano, regional, nacional ou supra nacional), diversas formas organizacionais da sociedade civil (câmaras de comércio, sindicatos, igreja, instituições educacionais e pesquisa, grupos comunitários, ONGs etc.) $e$ interesses privados (empresariais e individuais), formando coalizões para fomentar ou administrar o desenvolvimento urbano / regional de um tipo u de outro.

Contudo, o que observamos em São Paulo é uma união do Estado com uma elite local $^{35}$, que se articula com o plano do mundial, em ação para constituição do eixo empresarial, no sentido de reproduzir seus interesses e capitais num movimento real de transformação da economia da metrópole articulada com as transformações da economia global. Também não podemos negar que nesse processo a cidade passa a ser condição para valorização capitalista.

A idéia de "máquina do crescimento urbano"36 parece dar conta de sintetizar esse processo de articulação e ação desses grupos que agem no processo de produção do espaço no sentido dar novos conteúdos a cidade como negócio. Segundo Ferreira (2003:214), apoiado nas idéias de Logan \& Molotch $(1987)^{37}$, afirma que:

a máquina de crescimento ... se trata de um processo que lança mão de coalizões por parte das elites fundiárias, imobiliárias e políticas, qe possibilitam a apropriação de fundos públicos para alavancar lucros urbanos privados graças à utilizaçãoideológica das supostas imposições de competitividade da economia global...

Lefebvre (1976:42), também contribui para o debate. Escreve o Autor:

... a burguesia, a classe dominante, dispõe de um duplo poder sobre o espaço; em primeiro lugar, através da propriedade privada do solo, que

\footnotetext{
${ }^{35}$ Mas como veremos a frente, estamos cada vez mais próximos de uma internacionalização dos investidores do mercado imobiliário em São Paulo.

${ }^{36}$ A idéia de máquina de crescimento urbano é debatida em diversos trabalhos, entre eles Van Wilderode, 2000; Ferreira, 2003; Fix 2003 e Harvey, 2005.

${ }^{37}$ Urban Fortunes: the political economy of place. University of California Press, 1987.
} 
se estende à totalidade do espaço, exceção feita aos direitos das coletividades e do Estado, e, em segundo lugar, através da globalidade, a saber, o conhecimento, a estratégia, a ação do Estado propriamente dito. Existem conflitos inevitáveis entre esses dois aspectos, e especialmente entre o espaço abstrato (concebido ou conceitual, global e estratégico) e o espaço imediato, percebido vivido, esmigalhado e vendido. No plano institucional, essas contradições se fazem patentes entre os planos gerais de ordenação e os projetos parciais dos negociantes do espaço. ${ }^{38}$

No desenvolvimento de constituição do eixo empresarial, todos esses processos tomam forma e o faz uma região muito dinâmica da cidade, no sentido da economia de serviços, comércio, infra-estrutura pública e um importante setor imobiliário voltado a edifícios de escritórios da cidade.

Na seqüência, há algumas imagens do fragmento em questão e em seguida discutimos alguns dados importantes do mercado de edifícios de escritórios.
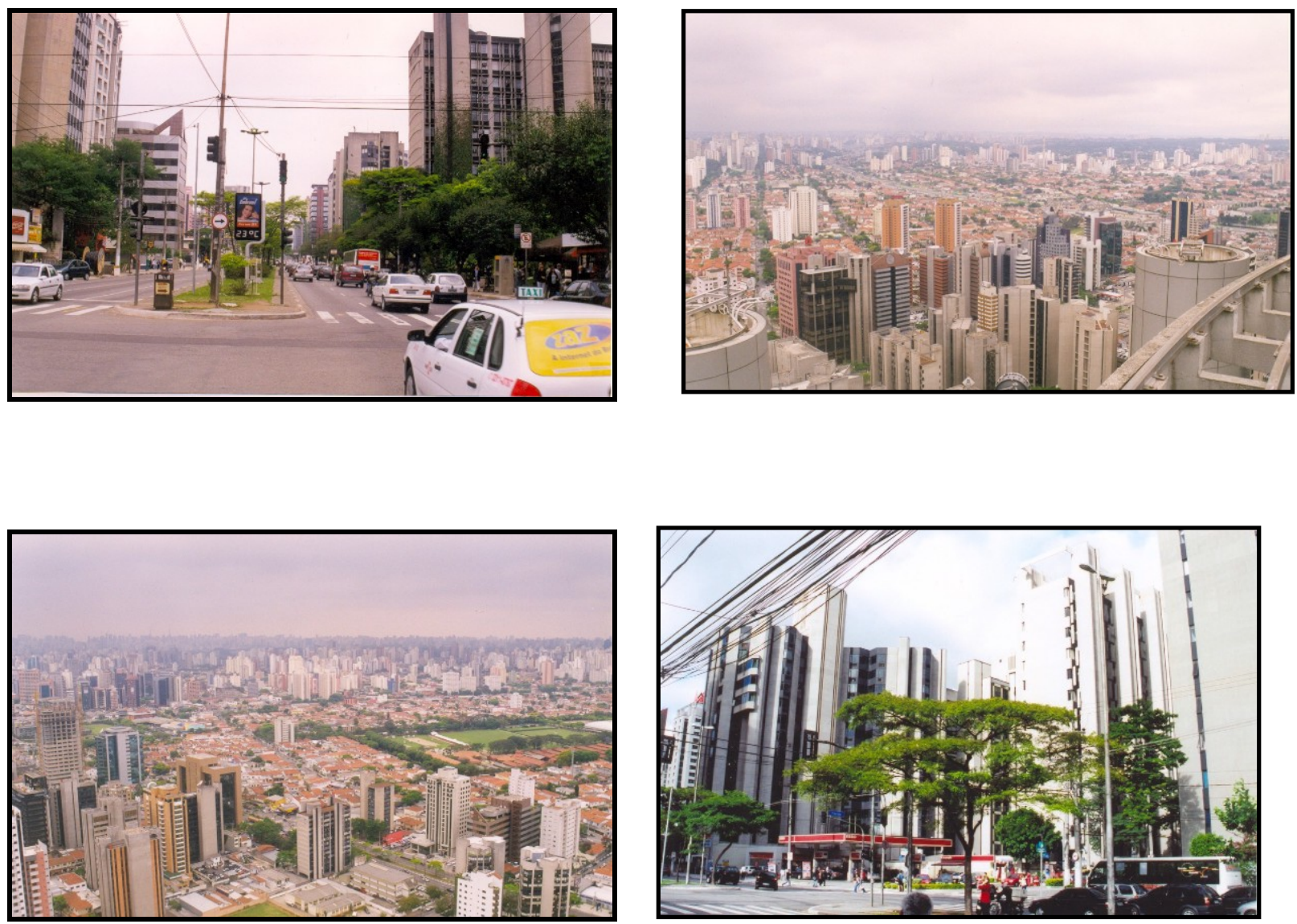

\footnotetext{
${ }^{38}$ Tradução do autor.
} 

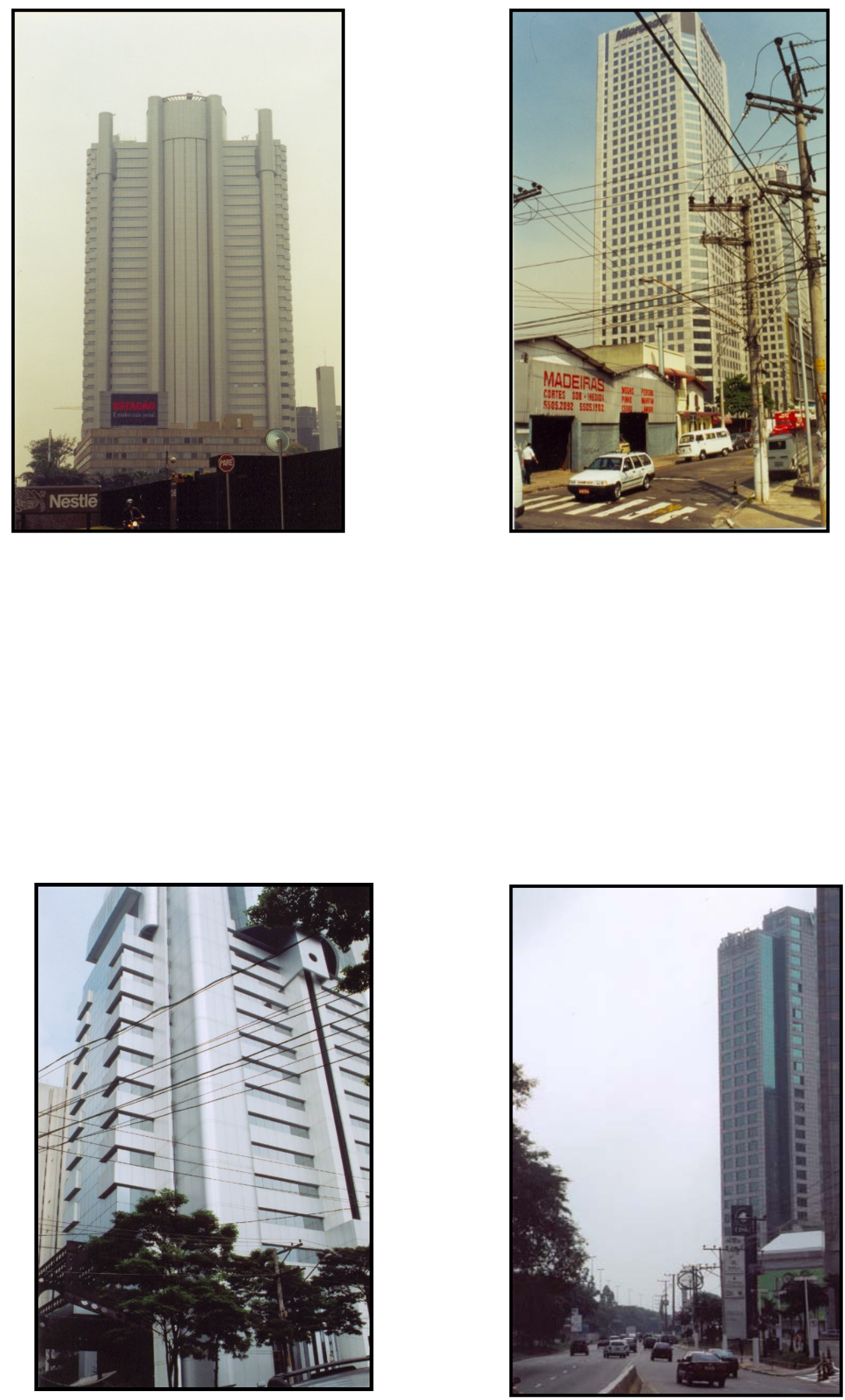

Fotos: Sávio Miele 

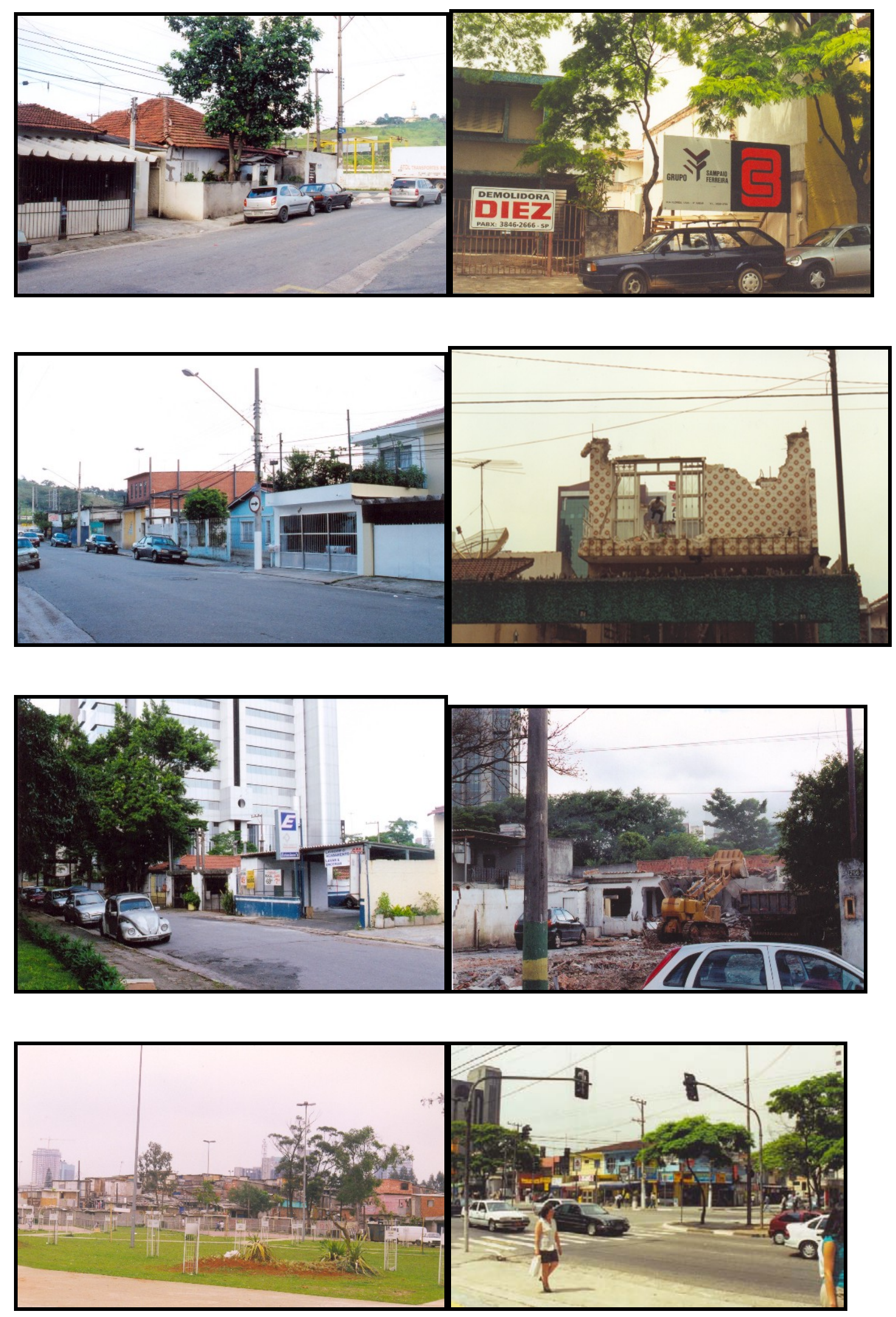

Fotos: Sávio Miele 

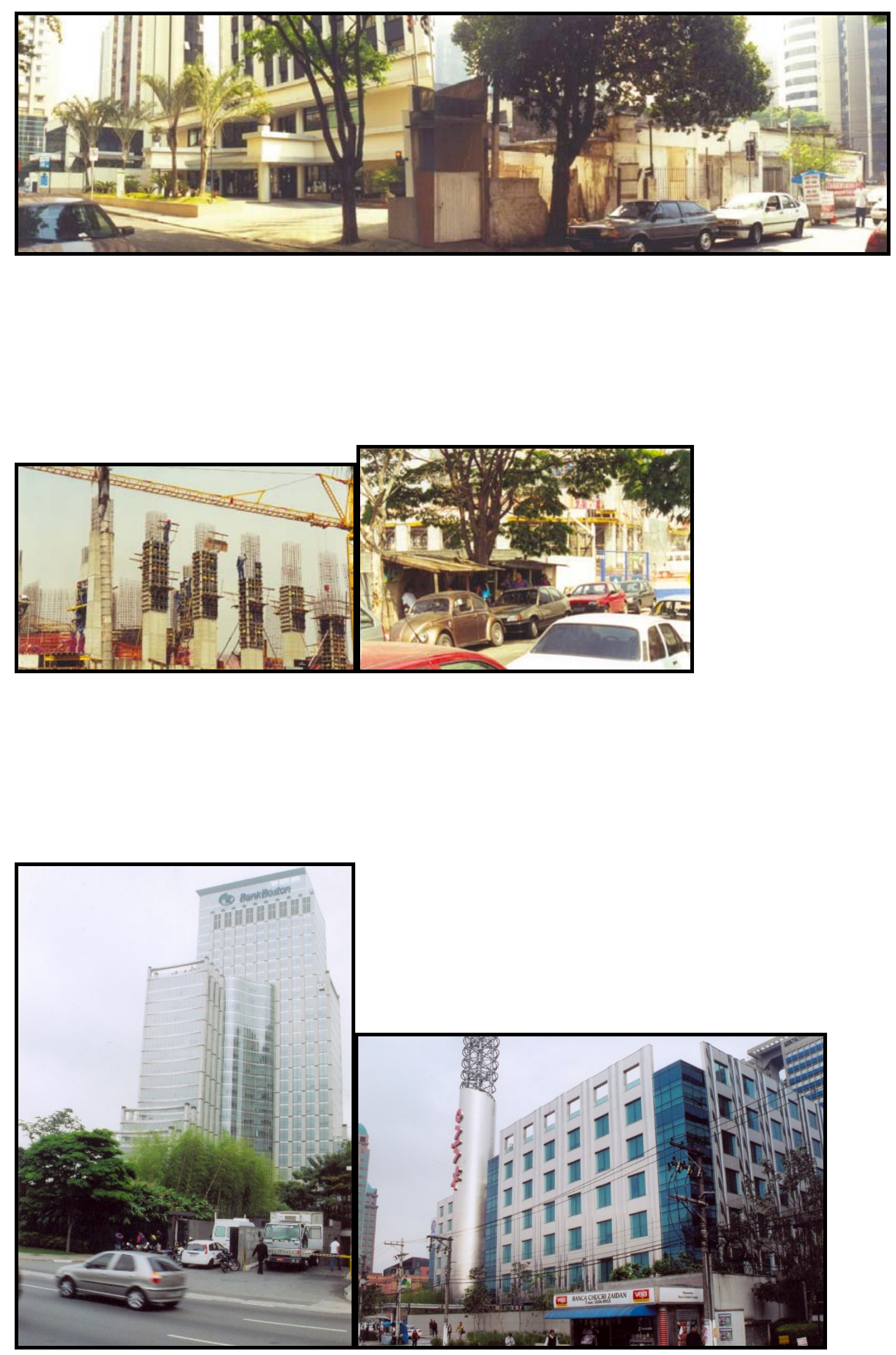

Fotos: Sávio Miele 

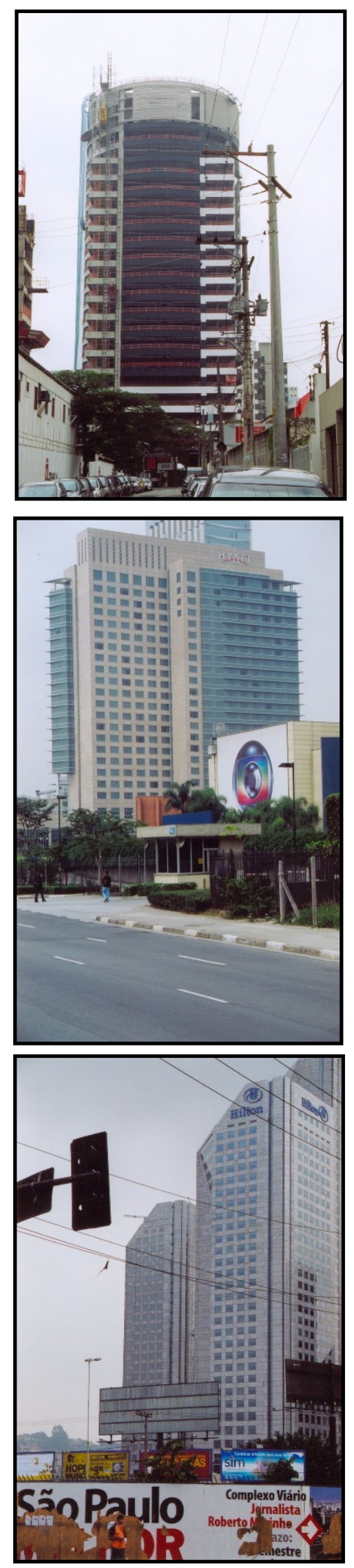

Fotos: Sávio Miele 
OPERAÇÃO URBANA ÁGUA ESPRAIADA
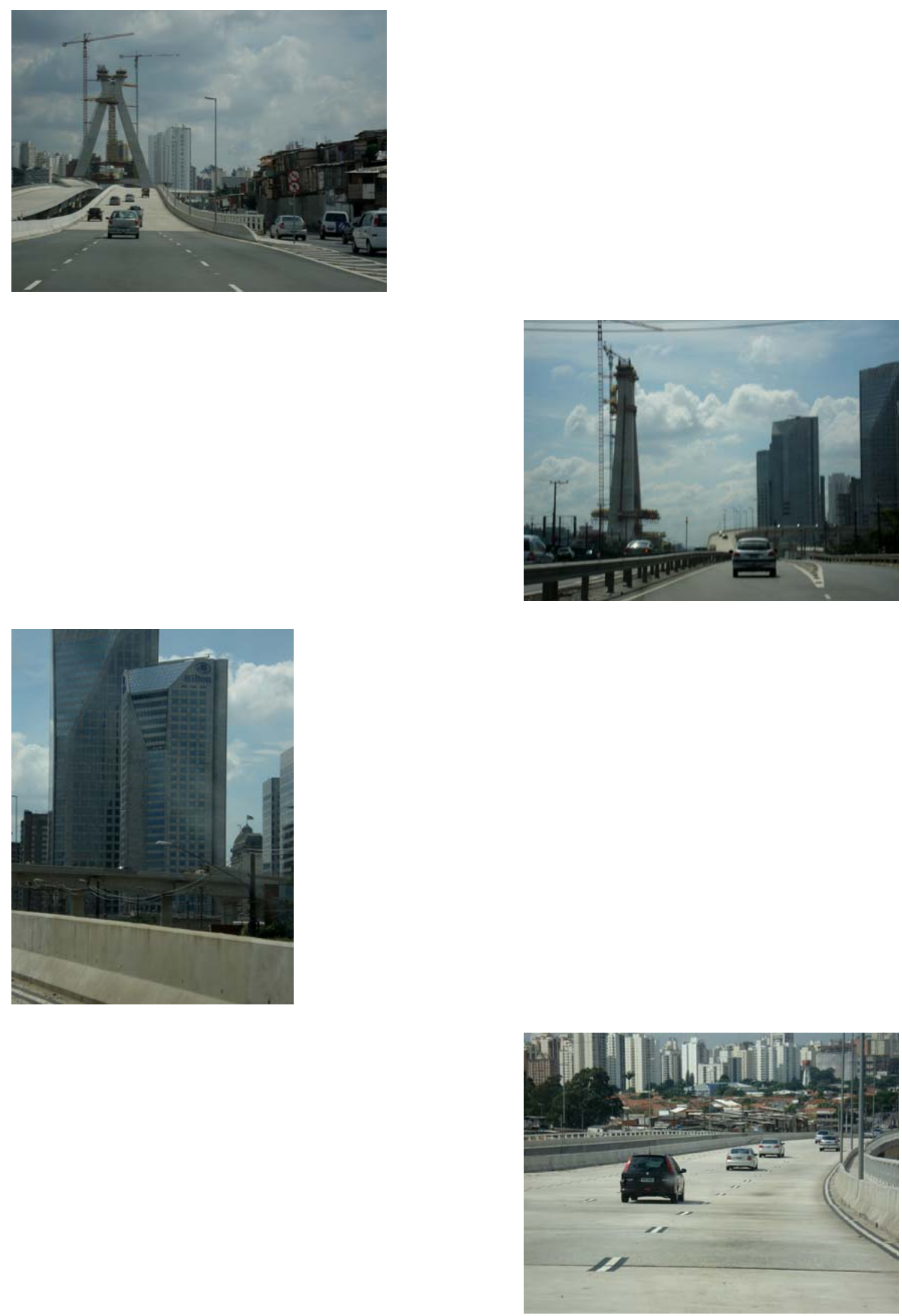

Fotos do autor. Abril, 2007. 
Na cidade de São Paulo, segundo a Embraesp, foram lançados 333 projetos de edifícios de escritórios no período entre 1992-2006; sendo que 52,85\% deles, ou seja, 176 empreendimentos, se concentram no eixo empresarial que se expande do centro da cidade em direção ao sudoeste/sul, conforme as tabelas 1 e $2^{39}$ abaixo.

\section{TABELA 1}

São Paulo: Números de lançamentos comerciais*

1992-2006

\begin{tabular}{|c|c|c|c|c|c|}
\hline Zona de Valor & Lanç. & Zona de Valor & Lanç. & Zona de Valor & Lanç. \\
\hline ACLIMAÇÃO & 4 & ITAQUERA & 1 & POMPÉIA & 3 \\
\hline ÁGUA BRANCA & 3 & JABAQUARA & 3 & SANTA CECÍLIA & 3 \\
\hline ALTO DA LAPA & 1 & JARDIM DA SAÚDE & 11 & SANTANA & 10 \\
\hline ALTO DE PINHEIROS & 1 & JARDIM EUROPA & 4 & SANTO AMARO & 3 \\
\hline BARRA FUNDA & 1 & JARDINS & 24 & SAÚDE & 2 \\
\hline BELA VISTA & 11 & LAPA & 3 & TATUAPÉ & 10 \\
\hline BOM RETIRO & 1 & LIBERDADE & 2 & TUCURUVI & 1 \\
\hline BROOKLIN & 13 & MANDAQUI & 1 & VILA CLEMENTINO & 12 \\
\hline CAMPO BELO & 6 & MOEMA & 17 & VILA FORMOSA & 1 \\
\hline CASA VERDE & 1 & MOOCA & 3 & VILA MADALENA & 3 \\
\hline CHÁCARA STO ANTONIO & 6 & MORUMBI & 11 & VILA MARIA & 1 \\
\hline HIGIENÓPLIS & 11 & PARAISO & 13 & VILA MARIANA & 14 \\
\hline IBIRAPUERA & 1 & PENHA & 2 & VILA NOVA CONCEIÇÃO & 5 \\
\hline IPIRANGA & 3 & PERDIZES & 15 & VILA OLÍMPIA & 37 \\
\hline ITAIM & 34 & PINHEIROS & 20 & VILA PRUDENTE & 1 \\
\hline
\end{tabular}

Fonte: Embraesp, 2007

* Prédios de escritórios.

A tabela 1 mostra o número de lançamentos comerciais na cidade de São Paulo por zona de valor no período 1992-2006. Como podemos observar o total de lançamentos neste período foi de 333 empreendimentos imobiliários de edifícios de escritórios em São Paulo.

A tabela 2 traz os dados sobre os lançamentos de edifícios de escritórios nas principais regiões de escritórios na cidade de São Paulo no período de 1992-2006.

A escolha desses lugares não foi aleatória e sim a partir do mapa 1 da Bolsa de Imóveis do Estado de São Paulo (BIESP) que mostra a expansão do centro em direção ao sudoeste/sul por meio da representação de nove regiões, que segundo o autor seriam as “principais regiões de escritórios em São Paulo”. Assim, elegemos Bela Vista e Higienópolis como dois bairros que representariam o centro já em expansão ${ }^{40}$, Jardins

\footnotetext{
39 A Tabela "2" é composta por 11 Zonas de Valor (nomenclatura utilizada pela Embraesp), sendo que duas delas encontram-se fundidas: aos dados referentes aos Jardins foram adicionados os dados da zona de valor Jardim Europa e aos dados referentes à Chácara Santo Antônio foram adicionados os dados da zona de valor Santo Amaro.

${ }^{40}$ É importante deixar claro que no centro de São Paulo não houve lançamentos de edifícios de escritórios no período. Na realidade, o que conhecemos como “centro histórico” é uma região altamente adensada e
} 
TABELA 2

São Paulo: Lançamentos de Edifícios de Escritórios (nas principais regiões de escritórios) 1992-2006

\begin{tabular}{|c|c|c|c|c|c|}
\hline \multicolumn{2}{|c|}{ BELA VISTA } & \multicolumn{2}{|c|}{ HIGIENÓPOLIS } & \multicolumn{2}{|c|}{ JARDINS } \\
\hline Ano & $\mathrm{N}^{\circ}$ Lanç. & Ano & $\mathrm{N}^{\circ}$ Lanç. & Ano & $\mathrm{N}^{0}$ Lanç. \\
\hline 1992 & 1 & 1992 & & 1992 & 2 \\
\hline 1993 & & 1993 & & 1993 & 1 \\
\hline 1994 & & 1994 & 1 & 1994 & 8 \\
\hline 1995 & & 1995 & 1 & 1995 & 2 \\
\hline 1996 & 2 & 1996 & 1 & 1996 & 5 \\
\hline 1997 & 1 & 1997 & 1 & 1997 & 2 \\
\hline 1998 & 1 & 1998 & 2 & 1998 & 2 \\
\hline 1999 & 1 & 1999 & & 1999 & \\
\hline 2000 & & 2000 & & 2000 & 1 \\
\hline 2001 & & 2001 & 2 & 2001 & 1 \\
\hline 2002 & 3 & 2002 & 2 & 2002 & \\
\hline 2003 & 1 & 2003 & & 2003 & 2 \\
\hline 2004 & 1 & 2004 & & 2004 & 1 \\
\hline 2005 & 0 & 2005 & & 2005 & \\
\hline 2006 & 0 & 2006 & 1 & 2006 & 1 \\
\hline Total & 11 & Total & 11 & Total & 28 \\
\hline \multicolumn{2}{|c|}{ PARAÍSO } & \multicolumn{2}{|c|}{ ITAIM } & \multicolumn{2}{|c|}{ PINHEIROS } \\
\hline Ano & $\mathrm{N}^{\circ}$ Lanç. & Ano & $\mathrm{N}^{0}$ Lanç. & Ano & $\mathrm{N}^{0}$ Lanç. \\
\hline 1992 & & 1992 & 2 & 1992 & 2 \\
\hline 1993 & & 1993 & 2 & 1993 & 2 \\
\hline 1994 & 2 & 1994 & 4 & 1994 & \\
\hline 1995 & 1 & 1995 & 3 & 1995 & \\
\hline 1996 & 3 & 1996 & 5 & 1996 & 4 \\
\hline 1997 & & 1997 & 4 & 1997 & 2 \\
\hline 1998 & 3 & 1998 & 2 & 1998 & 1 \\
\hline 1999 & & 1999 & 3 & 1999 & 5 \\
\hline 2000 & & 2000 & 1 & 2000 & 2 \\
\hline 2001 & 1 & 2001 & 2 & 2001 & \\
\hline 2002 & 1 & 2002 & 5 & 2002 & \\
\hline 2003 & & 2003 & & 2003 & 1 \\
\hline 2004 & & 2004 & & 2004 & \\
\hline 2005 & 2 & 2005 & & 2005 & 1 \\
\hline 2006 & & 2006 & 1 & 2006 & \\
\hline Total & 13 & Total & 34 & Total & 20 \\
\hline \multicolumn{2}{|c|}{ VILA OLÍMPIA } & \multicolumn{2}{|c|}{ BROOKLIN } & \multicolumn{2}{|c|}{ CHAC. STO ANTONIO } \\
\hline Ano & $\mathrm{N}^{\circ}$ Lanç. & Ano & $\mathrm{N}^{0}$ Lanç. & Ano & $\mathrm{N}^{0}$ Lanç. \\
\hline 1992 & & 1992 & 3 & 1992 & \\
\hline 1993 & & 1993 & 1 & 1993 & 1 \\
\hline 1994 & 1 & 1994 & 2 & 1994 & \\
\hline 1995 & 5 & 1995 & 2 & 1995 & \\
\hline 1996 & 4 & 1996 & & 1996 & 3 \\
\hline 1997 & 7 & 1997 & & 1997 & 1 \\
\hline 1998 & 5 & 1998 & 1 & 1998 & \\
\hline 1999 & 1 & 1999 & & 1999 & \\
\hline 2000 & 5 & 2000 & & 2000 & \\
\hline
\end{tabular}

que possui um grande número de edifícios de escritórios antigos. Por isso que não há lançamentos nesta região. 


\begin{tabular}{|c|c|c|c|c|c|}
\hline 2001 & 1 & 2001 & & 2001 & 1 \\
\hline 2002 & 4 & 2002 & & 2002 & 1 \\
\hline 2003 & 1 & 2003 & 1 & 2003 & \\
\hline 2004 & 1 & 2004 & 2 & 2004 & 1 \\
\hline 2005 & 1 & 2005 & & 2005 & 1 \\
\hline 2006 & 1 & 2006 & 1 & 2006 & \\
\hline Total & 37 & Total & 13 & Total & 9 \\
\hline
\end{tabular}

Fonte: Embraesp, 2007

(incluindo a Av. Paulista, trecho da Av. Brig. Faria Lima e Av. Rebouças), Paraíso, Itaim (incluindo trecho da Av. Brig. Faria Lima e Av. Juscelino Kubitschek), Pinheiros (incluindo trecho da Av. Brig. Faria Lima e trecho da Av. Nações Unidas) e Chácara Santo Antônio (incluindo área da rua Verbo Divino e trecho da Av. Nações Unidas).

Uma ressalva importante a ser feita é que a BIESP toma como as regiões mais importantes na produção de edifícios de escritórios os bairros por onde a expansão do eixo empresarial se dá. Em parte, pela razão de que este fragmento da metrópole possuiu no período entre 1992-2006 52,85\% dos projetos lançados em São Paulo, como afirmamos acima. Então de acordo com a tabela 2 os bairros onde mais houve número de lançamentos foram Vila Olímpia, com um total de 37 lançamentos; Itaim, com 34 lançamentos; nos Jardins houve 28 lançamentos e em Pinheiros um total de 20 lançamentos. Em outros bairros, como Bela Vista e Higienópolis houve em cada um 11 lançamentos, no Paraíso 13, no Brooklin também 13 e na Chácara Santo Antônio houve 9 lançamentos. Sem dúvida, juntos, esses bairros compõem uma região que possui a maior produção de edifícios de escritórios, como mostra o mapa 3 que representa lançamentos comerciais no mercado imobiliário, revelando uma concentração espacial de empreendimentos no fragmento em questão. Entretanto, faz-se necessário registrar aqui que há outros bairros de São Paulo (alguns localizados muito próximos ao eixo) que possuem uma quantidade de lançamentos de edifícios comerciais que deve ser registrada, pois possuem números semelhantes ou até mesmo superiores a bairros que compõem o eixo. Por exemplo, Moema, que possui, no período analisado, 17 lançamentos; Perdizes 15; Vila Mariana 14; Vila Clementino 12; Morumbi e Jardim da Saúde 11 em cada um e Santana e Tatuapé com 10 lançamentos em cada bairro. Estes exemplos podem ser um indicador que possibilite relativizar a atividade imobiliária voltada a edifícios de escritórios realizada na metrópole de São Paulo, que mesmo concentrada nesta região que se expande a partir do centro e atinge o sudoeste/sul, ou seja, mesmo sendo ele o lugar mais importante de produção de edifícios de escritórios 


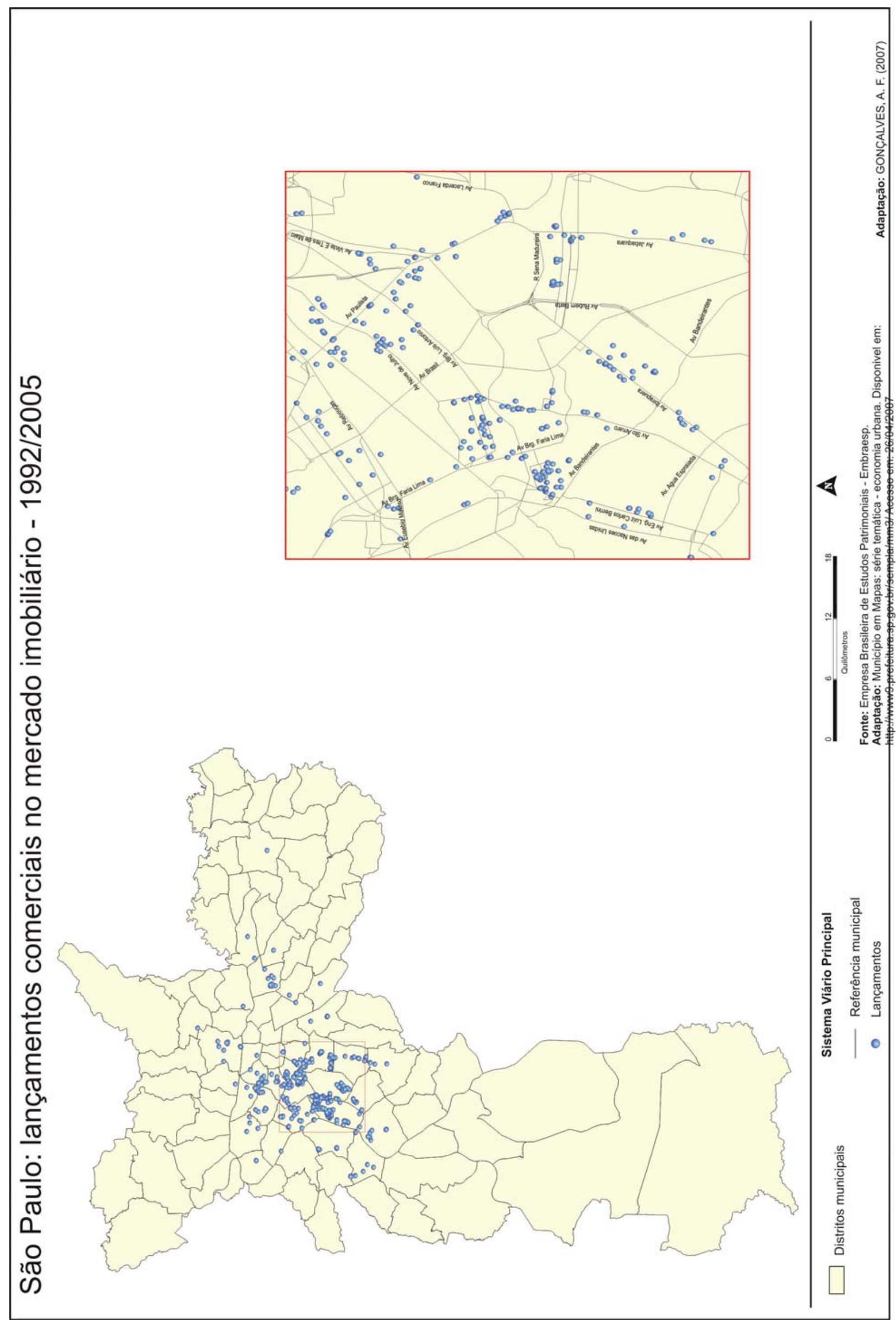


da metrópole, há em certos lugares uma quantidade de construção expressiva. Porém outros dados e, mesmo a particularidade do processo da produção do espaço urbano nesta região da metrópole, revelam a importância deste fragmento de expansão do centro. Além do número de lançamentos de imóveis é necessário analisar diversos indicativos que apontam para a importância que o eixo empresarial de São Paulo possui no processo de urbanização da metrópole. A apresentação será feita sempre que possível evidenciando uma relação do eixo com os lugares da metrópole onde o mercado imobiliário para escritório atua. Sendo possível assim não absolutizar o fragmento em questão.

A partir dos dados sobre a presença dos Incorporadores, Vendedores e Construtoras nos lançamentos do mercado imobiliário de escritório em São Paulo por zona de valor, podemos observar a existência de um grande número de empresas atuando na cidade como incorporadoras. De acordo com dados da Embraesp, atuaram em São Paulo no período de 1992-2006 como incorporadoras de empreendimentos comerciais 257 empresas; 16 das 257 estão presentes em 92 incorporações, ou seja, em 27,62\% dos lançamentos. As empresas Sinal Verde e Serplan estão presentes em 3,30\% dos lançamentos cada uma (cada uma participou de 11 incorporações ${ }^{41}$ ). Em seguida está a Cyrela em 2,70\% dos lançamentos (participando de nove incorporações). A INPAR participa como incorporadora de 2,10\% dos empreendimentos lançados (participando de sete incorporações). Company e Brazil Realty estão presentes em 1,80\% dos lançamentos cada uma (participando de seis incorporações cada). A Simeira e BIESP em 1,50\% cada uma (o que significa cinco incorporações cada). Presentes, cada uma, em 1,20\% do total de lançamentos do período estão as incorporadoras Stan, Plano Melhor, Encol, Conceito, Kauffmann, Porte, Pinheiros AIP e Lucio (participando de quatro incorporações cada uma). Os lançamentos restantes estão assim divididos: 11 empresas realizaram no período três incorporações cada; 42 empresas realizaram duas incorporações cada; e a grande maioria, 189 empresas (73,54\%), realizou uma incorporação cada no período em questão. Assim, com relação à incorporação podemos afirmar que há um grande número de empresas que participaram de incorporações de edifícios comerciais, revelando que há neste setor uma grande pulverização em termos do número de empresas que atuam como incorporadoras no mercado imobiliário voltado a produção de prédios de escritórios de São Paulo entre 1992-2006.

\footnotetext{
${ }^{41}$ Dados referentes à quantidade de vezes que uma empresa participou de alguma incorporação, sendo ela única incorporadora ou em parceria com outras empresas.
} 
Com relação às comercializações os dados mostram que existe uma concentração um pouco maior de empresas vendedoras nos lançamentos comerciais em relação à presença das incorporadoras: os 333 lançamentos foram comercializados por 107 empresas. A Lopes está presente em 18,91\% dos lançamentos comercializados, o que significa a participação em 63 comercializações. Em seguida, está Coelho da Fonseca, que participa em 10,21\% dos lançamentos, representando 34 comercializações realizadas. Fernandez Mera está em 6,30\% dos lançamentos, com 21 comercializações. Na seqüência é a Abyara, que participa em 4,50\% dos empreendimentos lançados, o que significa 15 lançamentos comercializados pela empresa. Sivercon se encontra em 3,60\% dos lançamentos, com a comercialização de 12 empreendimentos. Essas são as 5 empresas vendedoras que participaram em 145 lançamentos, ou seja, em 43,54\% do total de lançamentos de edifícios de escritórios em São Paulo no período de 1992-2006. Outras 102 estiveram presentes em 30,63\% dos lançamentos. Por meio destes números observamos então uma maior concentração de lançamentos comercializados pelas empresas vendedoras no mercado para prédios de escritórios, bem como uma diminuição da pulverização, pois aqui 62 empresas estiveram presentes somente em um lançamento, ou seja, 57,94\% delas estiveram em um lançamento; enquanto que em relação às incorporadoras, $73,54 \%$ delas estiveram presentes no mercado em um lançamento cada.

Já por meio dos dados sobre as construtoras observamos uma situação mais próxima a das incorporadoras. O total de empresas construtoras que atuaram no mercado imobiliário para escritórios em São Paulo no período 1992-2006 foi 192. A empresa que mais participou em lançamentos como construtora foi a Cyrela, 3,90\% dos empreendimentos lançados, o que representa 13 empreendimentos. Logo em seguida está a Sivercon, que se encontra em 3,60\% dos lançamentos, com presença em 12 lançamentos. A RFM está em 2,40\% dos lançamentos, o que significa presença em oito lançamentos. A Company participou em 2,10\% dos imóveis lançados, o que representa participação em sete lançamentos. Cinco empresas ocupam a quinta posição participando cada uma de cinco lançamentos. Essas empresas são Conceito, F Reis, INPAR, Barbará, Simeira. Então observamos que nove empresas construtoras estão em 19,51\% dos lançamentos; de 192 empresas construtoras 127 (66,14\%) estavam em apenas um lançamento e 35 dessas empresas, ou seja, 18,22\% participaram de apenas dois lançamentos. Assim, podemos afirmar que em relação às construtoras há um 
grande número de empresas atuantes no mercado, caracterizando uma pulverização dessas empresas na cidade.

A partir da análise desses dados podemos afirmar que o mercado imobiliário para edifícios de escritórios em São Paulo é bastante pulverizado entre as empresas, ou seja, não há uma concentração dos lançamentos imobiliários nas mãos de poucas empresas. Observamos uma grande quantidade de empresas que participou cada uma apenas em um lançamento e um número pequeno de empresas que não estão presentes na maior parte dos lançamentos, conforme os dados acima. Por outro lado, como mostra a tabela S e o mapa z, há uma concentração espacial dos empreendimentos de edifícios de escritórios nos bairros que compõem o eixo empresarial de São Paulo.

Esses mesmos dados devem ser analisados para o fragmento em questão para observarmos no que a dinâmica das empresas se diferencia ou não do movimento observado para São Paulo como um todo. Conforme dados da Embraesp, a empresa que mais participou de lançamentos foi a Serplan, presente em 6,81\% dos lançamentos (participando de doze incorporações). Seguida pela Cyrela com presença em 5,11\% dos lançamentos (esteve presente em nove incorporações). Logo depois se encontra a Brazil Realty que esteve presente em 3,40\% das incorporações (participou de seis incorporações). A BIESP, Kauffmann, Conceito e Sandria estiveram presentes cada uma em 2,27\% dos lançamentos (participando cada uma de quatro incorporações). Das 154 empresas as sete empresas citadas acima estiveram presentes em 24,43\% dos lançamentos; cinco empresas estiveram presentes em três lançamentos cada uma; 27 empresas participaram de dois lançamentos cada e 115 empresas participaram de um lançamento cada.

De acordo com os números acima podemos afirmar que a atividade de incorporação no mercado imobiliário de escritórios no eixo empresarial acompanha a mesma dinâmica da metrópole paulistana, isto é, caracteriza-se pela pulverização de diferentes empresas nas nove regiões que compõem o eixo de expansão.

Os dados sobre comercialização mostram que a empresa que mais comercializou edifícios de escritórios no eixo foi a Lopes, que participou em 15,90\% dos lançamentos (esteve presente como vendedora em 28 lançamentos). A empresa Coelho da Fonseca teve participação em 11,36\% dos lançamentos (o que significa que esta empresa teve presença em 20 lançamentos como vendedora). Em seguida se encontra a empresa Fernandez Mera que participou em 7,95\% dos lançamentos. Essas três empresas vendedoras juntas estiveram presentes em 62 lançamentos, o que representa 35,22\% dos 
lançamentos. Das 64 empresas que participaram de lançamentos comerciais no eixo empresarial 13 empresas participaram de dois lançamentos cada e 35 participaram em um lançamento cada, ou seja, em 19,88\% dos lançamentos.

A análise dos dados acima revela que há uma diminuição da pulverização de empresas vendedoras no eixo empresarial, entretanto podemos observar uma concentração de vendas na mão de algumas poucas empresas, pois como vimos três empresas juntas participaram em 62 lançamentos, o que significa 35,22\% do total de lançamentos no eixo empresarial.

A respeito da participação das empresas construtoras os números mostram que a empresa Cyrela participou como construtora em 7,38\% dos lançamentos do mercado imobiliário de escritórios no eixo empresarial (participando de 13 lançamentos). Em seguida está a RFM, que esteve presente em 3,97\% dos lançamentos (com presença em sete lançamentos). A empresa Conceito participou em 2,84\% dos lançamentos (com participação em cinco lançamentos). As empresas Goldfarb, Kauffmann, F Reis, Camargo Correa estiveram presentes cada uma em 2,27\% dos lançamentos (sendo que cada uma participou de quatro lançamentos). Das 110 empresas construtoras que atuaram no mercado imobiliário de escritórios no eixo empresarial de São Paulo no período 1992-2006, 16 participaram de dois lançamentos cada e 78 participaram em apenas um lançamento cada uma. Dessas 110 empresas sete empresas construtoras estão presentes em 41 lançamentos (23,29\% dos lançamentos).

Desta forma, observamos que há uma pulverização das empresas no eixo, pois grande parte delas 70,90\% participou em apenas um lançamento. Porém, não há uma concentração nas mãos de um pequeno número de empresas, porque 6,36\% são responsáveis por 23,29\% dos lançamentos.

Através desses números observamos que ocorre no eixo empresarial da metrópole a mesma dinâmica que existe na cidade de São Paulo com relação ao mercado imobiliário para escritórios no período de 1992-2006, porque não há um pequeno grupo de empresas que concentram as atividades de incorporação, comercialização e construção, mas há sempre um pequeno grupo com mais destaque, isto é, participaram de mais lançamentos em comparação às outras empresas. Tanto na cidade de São Paulo como em seu eixo empresarial há algumas diferenças entre as atividades de incorporação, que possui o maior número de empresas e a maior pulverização, de comercialização que possui a menor pulverização e presença de um número de empresas inferior ao das atividades de incorporação e construção que se 
aproxima da dinâmica das empresas incorporadoras, ou seja, o número de empresas volta a crescer, caracterizando maior pulverização, pois a maior parte das empresas participa de apenas um lançamento cada. Entretanto, observamos que no fragmento em questão há uma concentração espacial das empresas que possuem maior participação nos lançamentos nos bairros onde esses ocorrem em maior quantidade. Além disso, essas empresas estão entre as consideradas pela Embraesp como as maiores da Grande São Paulo. O que vai ser diferente para a cidade de São Paulo como um todo, pois como vimos anteriormente, as empresas que mais participaram de atividades imobiliárias não necessariamente estão no eixo e as empresas que mais atuam no eixo encontram-se nos bairros que tiveram o maior número de lançamentos deste fragmento. Então não há uma concentração do mercado imobiliário para escritórios nas mãos de algumas empresas, mas há, no eixo em questão, uma concentração espacial das empresas de maior destaque nos bairros onde a construção de edifícios de escritórios é mais intensa.

Então vejamos essa concentração espacial dos lançamentos realizados pelas empresas imobiliárias que mais tiveram destaque no mercado imobiliário de escritórios no eixo empresarial de São Paulo. A análise será realizada considerando as empresas e as três atividades, ou seja, incorporação, comercialização e construção.

Com relação à incorporação temos que a empresa Serplan participou de quatro incorporações nos Jardins, sendo duas como única empresa e duas com parcerias (NTR e Bueno Netto); cinco incorporações no Itaim, sendo três como única empresa e duas com parcerias (Moraes Sampaio e Boghosian e Cyrela); uma incorporação em Pinheiros com parceria (Fortaleza) e duas incorporações no Brooklin, sendo uma como única empresa e outra com parceria (F Reis). A Cyrela participou de uma incorporação na Bela Vista com parceria (Brazil Realty); duas incorporações nos Jardins, sendo ambas como única empresa; duas incorporações no Itaim, sendo uma como única empresa e outra com parceria (Boghosian e Serplan); três incorporações na Vila Olímpia, sendo duas como única incorporadora e uma com parceria (Tecnisa) e uma incorporação no Brooklin como única empresa. A Brazil Realty participou de uma incorporação na Bela Vista com parceria (Cyrela Sunset); duas incorporações no Itaim como única empresa; duas incorporações na Vila Olímpia como única empresa e uma incorporação na Chácara Santo Antônio como única empresa. A BIESP participou de duas incorporações na Vila Olímpia, ambas com parceiras (Barbará, Stan, RGB) e duas incorporações no Brooklin como única empresa. A Kauffmann esteve presente em uma incorporação nos Jardins, sendo única empresa; três no Itaim, sendo ambas como única 
empresa. A empresa Conceito participou de duas incorporações no Itaim, sendo ambas com parcerias (Halna, Sampaio Bacos e Chap); duas incorporações na Vila Olímpia, sendo uma como única empresa e outra com parcerias (Constrac, Marino, DMF). A

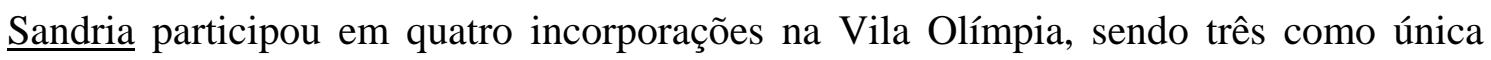
empresa e uma com parceiras (Fortaleza e M5).

Sobre as atividades de comercialização observamos que a empresa Lopes participou de duas comercializações na Bela Vista; duas em Higienópolis; cinco nos Jardins; duas no Paraíso; cinco no Itaim; duas em Pinheiros; oito na Vila Olímpia; de uma no Brooklin e de uma comercialização na Chácara Santo Antônio. A Coelho da Fonseca esteve presente em duas incorporações na Bela Vista; duas incorporações em Higienópolis; quatro nos Jardins; uma no Paraíso; duas no Itaim; duas em Pinheiros; cinco na Vila Olímpia; uma no Brooklin e uma comercialização na Chácara Santo Antônio. A empresa Fernandez Mera participou de uma comercialização na Bela Vista; quatro nos Jardins; de uma no Paraíso; três no Itaim; uma na Vila Olímpia; uma no Brooklin e de duas incorporações na Chácara Santo Antônio. A Abyara esteve presente com duas comercializações nos Jardins, sendo uma como única empresa e outra com parceria (SG21 e Seller); uma no Itaim; uma em Pinheiros; quatro incorporações na Vila Olímpia, sendo uma como única empresa e as outras três com parceiras (Bueno Netto, SG21 e Seller).

Com relação às empresas construtoras a Cyrela construiu um empreendimento na Bela Vista; dois nos Jardins; três no Itaim; cinco na Vila Olímpia; um no Brooklin e um na Chácara Santo Antônio. A empresa RFM esteve presente nos lançamentos comerciais no eixo como construtora em um empreendimento na Bela Vista; em quatro no Itaim; um em Pinheiros e em um empreendimento na Vila Olímpia. A empresa Conceito participou como construtora de um empreendimento na Bela Vista; dois no Itaim, sendo que um como única empresa e outro com parceria (Sampaio Bacos) e de dois empreendimentos na Vila Olímpia.

Estes dados revelam que as empresas que participaram da maioria dos lançamentos de edifícios comerciais no eixo empresarial de São Paulo no período 19922006 concentram suas ações (umas mais outras menos) nos bairros dos Jardins, Itaim e Vila Olímpia, sendo estes os bairros que mais tiveram lançamentos comerciais na cidade: 28, 34, 37 respectivamente. Então podemos afirmar que há uma concentração espacial das atividades imobiliárias dessas empresas nesses três bairros do eixo. Já para a cidade de São Paulo como um todo essa concentração espacial não acontece, como 
prova disso temos que a empresa que mais participou de atividades de incorporação foi a Sinal Verde, empresa que não tem nenhuma incorporação nos bairros que compõem o eixo empresarial. Mesmo a Lopes que é a empresa que mais comercializa edifícios de escritórios em São Paulo, 63, não comercializa metade desse número no eixo empresarial, que é a empresa que mais participou de comercializações nesta região da metrópole.

O fato é que temos uma pulverização de empresas tanto na cidade de São Paulo quanto nos bairros que compõem o eixo empresarial, mas no eixo concentram-se a maior quantidade de edifícios de escritórios e estão presentes concentradamente em três bairros as maiores empresas imobiliárias de São Paulo. Como podemos observar as tabelas A, B e C da Embraesp contém, em seu levantamento sobre as maiores empresas da Grande São Paulo ${ }^{42}$, as empresas que mais participam de lançamentos no eixo empresarial de São Paulo.

\section{TABELA 3}

Grande São Paulo: Ranking das Incorporadoras em 2005

\begin{tabular}{|c|l|r|}
\hline Posição & \multicolumn{1}{|c|}{ Incorporadora } & \% do mercado \\
\hline $1 a$ & Cyrela Brazil Realty & 5,19 \\
\hline $2 a$ & Gafisa & 3,6 \\
\hline 3a & Even & 2,55 \\
\hline 4a & Company & 2,12 \\
\hline 5a & Goldfarb & 1,74 \\
\hline 6a & Tecnisa & 1,72 \\
\hline 7a & Camargo Correa & 1,49 \\
\hline 8a & Sama Treviso & 1,41 \\
\hline 9a & M Bigucci & 1,41 \\
\hline $10 a$ & Tricury & 1,4 \\
\hline Estas 10 empresas & & 22,64 \\
\hline Fonte: Embraesp, 2007. & & \\
\hline
\end{tabular}

TABELA 4

Grande São Paulo: Ranking das Vendedoras em 2005

\begin{tabular}{|c|l|r|}
\hline Posição & \multicolumn{1}{|c|}{ Vendedora } & \% do mercado \\
\hline 1a & Lopes & 24,45 \\
\hline $2 \mathrm{a}$ & Abyara & 15,34 \\
\hline 3a & Fernadez Mera & 5,92 \\
\hline $4 \mathrm{a}$ & Coelho da Fonseca & 4,92 \\
\hline $5 \mathrm{a}$ & Itaplan & 4,37 \\
\hline $6 \mathrm{a}$ & Exclusiva & 2,25 \\
\hline $7 \mathrm{a}$ & Nossa Casa & 2,14 \\
\hline $8 \mathrm{a}$ & Triumpho & 2,03 \\
\hline 9a & Iprice & 1,71 \\
\hline
\end{tabular}

\footnotetext{
${ }^{42}$ Trata-se de um ranking realizado pela Embraesp para toda Grande São Paulo, incluindo todos os lançamentos residenciais (verticais e horizontais) e todas as unidades (tipo e cobertura), bem como todos os lançamentos de prédios de escritórios.
} 


\begin{tabular}{|c|c|c|}
\hline $10 \mathrm{a}$ & Del Forte & 1,68 \\
\hline Estas 10 empresas & & 64,79 \\
\hline
\end{tabular}

TABELA 5

Grande São Paulo: Ranking das Construtoras em 2005

\begin{tabular}{|c|l|r|}
\hline Posição & \multicolumn{1}{|c|}{ Construtora } & \% do mercado \\
\hline 1a & Cyrela/Brazil Realty & 5,21 \\
\hline 2a & Gafisa & 4,49 \\
\hline 3a & Company & 3,51 \\
\hline 4a & Even & 3,35 \\
\hline 5a & Setin & 2,1 \\
\hline 6a & Goldfarb & 1,96 \\
\hline 7a & Camargo Correa & 1,95 \\
\hline 8a & Tecnisa & 1,77 \\
\hline 9a & M Bigucci & 1,74 \\
\hline 10a & Tricury & 1,6 \\
\hline Estas 10 empresas & & 27,68 \\
\hline
\end{tabular}

Fonte: Embraesp, 2007

O conjunto de mapas apresentados a seguir trazem informações acerca dos edifícios de escritórios, chamando a atenção para a relação entre suas localizações em São Paulo e suas áreas, bem como andares e números e áreas dos conjuntos-tipo lançados na metrópole.

O mapa 1, sobre o total de área útil lançada e média de conjuntos-tipo por lançamento, revela uma concentração da produção de edifícios de escritórios no setor sudoeste/sul da cidade de São Paulo. Podemos observar, por meio das informações nele contidas, que quanto maior a área total lançada em $\mathrm{m}^{2}$, menor a média de números de conjuntos por lançamento. O que nos indica que no eixo empresarial da metrópole constrói-se em grande quantidade em comparação às outras regiões edifícios com menor número de conjuntos - são os prédios com as maiores lajes, superiores a $700 \mathrm{~m}^{2}$, podendo alcançar metragens que giram em torno de $2.000 \mathrm{~m}^{2}$. Esses edifícios na sua maior parte estão localizados no Itaim, Vila Olímpia e Marginal Pinheiros.

O mapa 2, sobre a média de área útil dos conjuntos-tipo mostra que as regiões das avenidas Paulistas, Faria Lima, Berrini e Marginal Pinheiros são as que possuem as maiores médias de área útil com relação aos conjuntos tipo lançados. O que pode nos levar a afirmar que os edifícios que foram lançados nestas regiões possuem os maiores conjuntos, o que justifica nossa afirmação anterior de que estas regiões possuem os edifícios com as maiores lajes. 

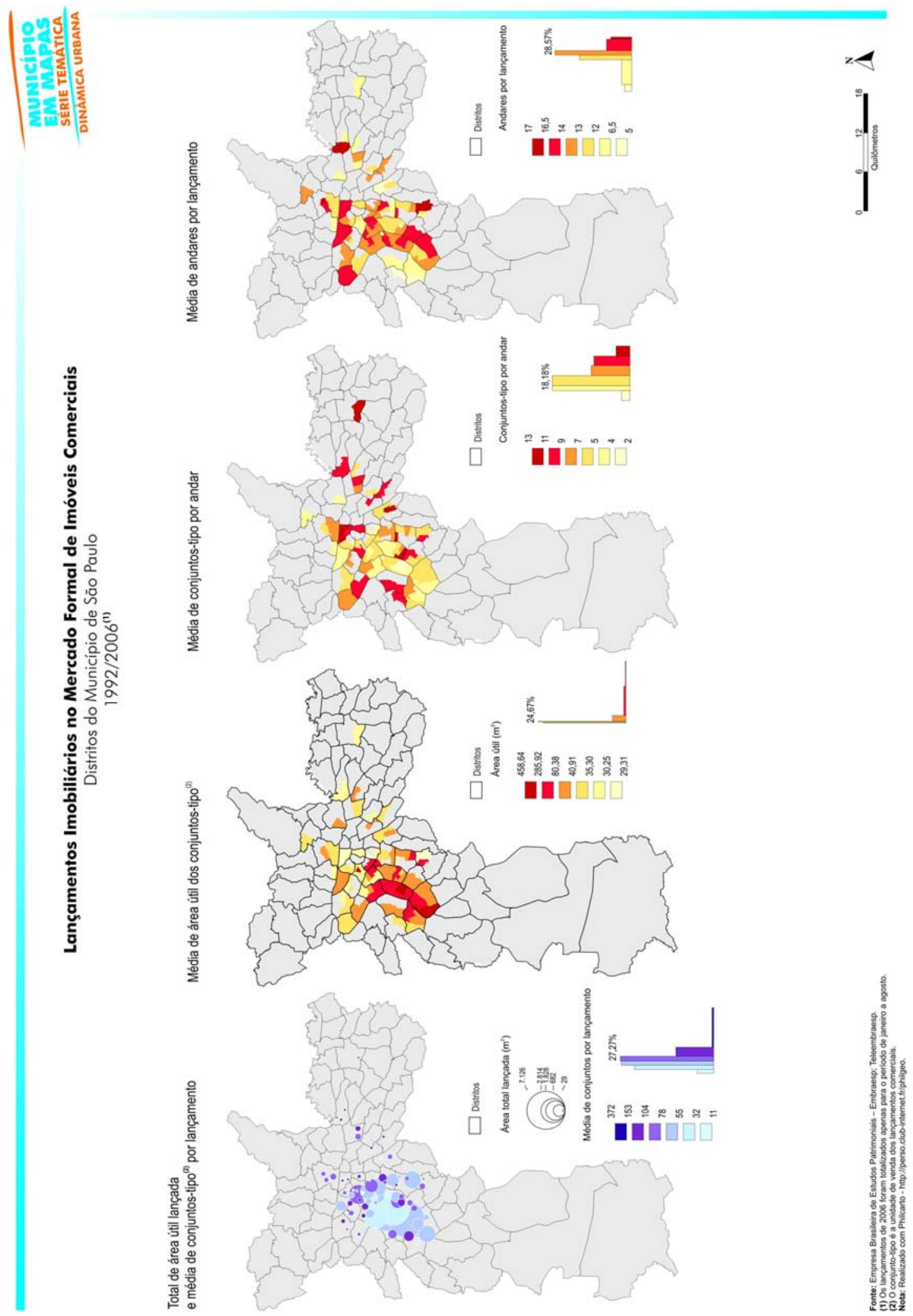
O mapa 3, a respeito da média de conjuntos-tipo por andar, mostra que a região do eixo empresarial é onde se localizam (com exceção do centro) os edifícios que possuem o menor número de conjuntos por andar, variando entre dois e seis conjuntos por andar em um edifício. Esse dado revela que tais prédios são construídos para serem utilizados por empresas de grande porte, de perfil corporativo, ocupando então edifícios que possuem grandes lajes, o que vai proporcionar uma quantidade menor de conjuntos, porém muito amplos.

O mapa 4, traz informações sobre a média de andares por lançamentos. Podemos observar que a média no eixo varia em torno de 12 a 17 andares, porém há edifícios ícones desse processo em São Paulo que possuem mais de 30 andares como as torres do CENU, o Plaza Centenário, e outros que possuem mais de 25. Ou seja, há uma diferenciação bastante grande quanto a esse ponto.

Como últimos dados a serem analisados, temos a média do preço por $\mathrm{m}^{2}$ de área útil em dólar para a cidade de São Paulo, bem como esses mesmos números para as zonas de valor nas principais regiões de escritórios em São Paulo ${ }^{43}$.

\section{SÃO PAULO: PRÉDIOS DE ESCRITÓRIOS} 1990 - 2006

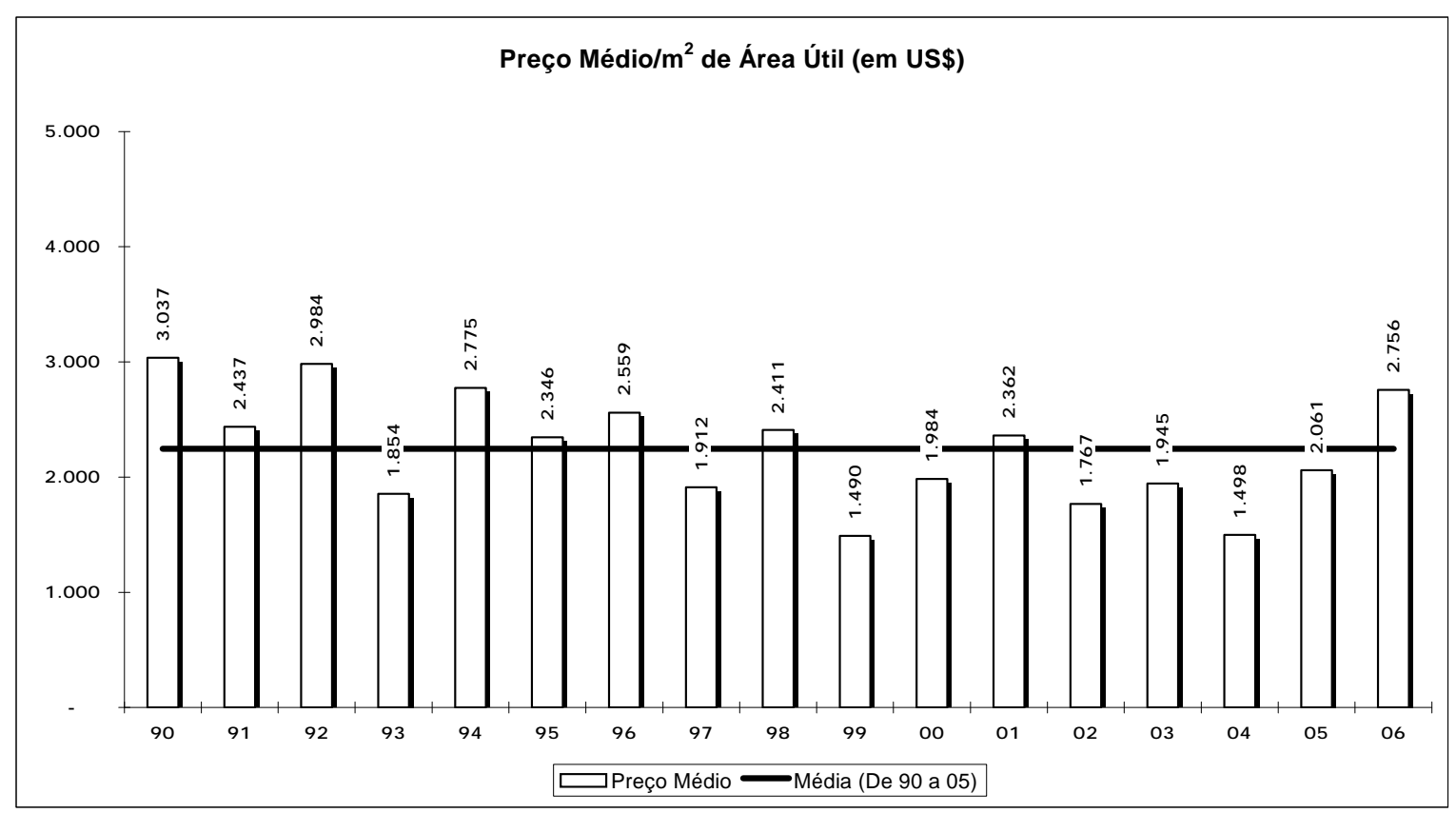

Fonte: Embraesp, 2007.

\footnotetext{
43 A Embraesp disponibiliza esses dados em dólares e em reais. Os preços aparecem em dólares pelo motivo de que a flutuação do real frente ao dólar mostra sempre uma subida do preço do $\mathrm{m}^{2}$, o que não ocorre na realidade, pois essa suposta valorização constante se dá pelo fato de que o real se desvalorizou frente ao dólar nos últimos seis anos. Por isso mantivemos os preços em dólares para conseguirmos observar o verdadeiro movimento dos preços do $\mathrm{m}^{2}$ de aérea útil para edifícios de escritórios.
} 
Os dados contidos no gráfico acima mostram que o preço do $\mathrm{m}^{2}$ de área útil para edifícios de escritórios em São Paulo variou de US\$ 1.490,00 a US\$ 3.037,00 no período 1990-2006. É importante observar que há momentos em que os preços estão mais baixos e mais altos, o que nos leva a afirmar que não há uma valorização contínua do preço do $\mathrm{m}^{2}$ para no mercado de edifícios de escritórios. A média do preço esteve em torno de 2.300,00 dólares na cidade de São Paulo.

A tabela 6, a seguir traz esses mesmos dados para o período de 1995-2006 nas zonas de valor que compõem o eixo empresarial de São Paulo. Nos bairros da Bela Vista, Paraíso e Pinheiros, a média dos preços do $\mathrm{m}^{2}$ decaiu. Na Bela Vista em 1996 a média era de 2.455,00 dólares e passou para 1.684,02 dólares em 2004, último ano em que houve lançamentos no bairro. No Paraíso (bairro que teve a maior queda), a média do preço do $\mathrm{m}^{2}$ em 1995 que era de 3.416,52 dólares passou a 1.845,00 dólares em 2005. Em Pinheiros, a média passou de 2.963,44 dólares em 1996 para 2.388,25 dólares em 2005, último ano em que houve lançamentos no bairro. Mantiveram-se com a média do preço do $\mathrm{m}^{2}$ estável, com muito pouca variação, os bairros de Higienópolis, onde em 1995 a média era de 2.518,65 dólares e em 2006 a média passa a ser de 2.537,00 dólares e Vila Olímpia que em 1995 o preço médio do m² $^{2}$ era de 2.414,23 dólares e em 2006 de 2.508,78 dólares. Os bairros que tiveram aumento na média do preço do $\mathrm{m}^{2}$ de área útil foram Itaim, Brooklin e Chácara Santo Antônio. O bairro do Itaim a média do preço do $\mathrm{m}^{2}$ era de 2.297,21 dólares em 1995 e passou a ser de 5.651,56 dólares em 2006. No Brooklin, em 1995 a média era de 2.038,85 dólares e passa a ser em 2006 2.951,19 dólares. Na Chácara Santo Antônio, em 1996 a média do $\mathrm{m}^{2}$ era de 2.359,83 dólares e em 2005 passou a ser de 2.604,24 dólares.

Utilizamos os anos inicial e final que formam o período aqui analisado para ilustrar a dinâmica dos preços no mercado imobiliário somente para mostrar que no movimento de constituição do eixo empresarial há momentos nos quais o preço do solo urbano pode subir ou abaixar de acordo com alguns condicionantes (principalmente abaixar, pois observamos assim que não há uma valorização constante do solo que leve o preço a subir sempre). Tais como a questão da demanda, a questão das tecnologias de construção e de automação predial, o tamanho dos empreendimentos e a presença ou não de lançamentos no bairro e as características dos imóveis lançados são elementos que fazem com que o preço praticado em cada lugar tenha alterações. É importante observar que a tabela de cada bairro mostra que no período analisado há muitas variações das médias desses preços para cima e para baixo, o que vai caracterizar o 
TABELA 6

São Paulo 1995-2006: Média do preço por $\mathrm{m}^{2}$ de área útil em US\$ por zona de valor nas principais regiões de escritórios*

\begin{tabular}{|c|c|}
\hline \multicolumn{2}{|c|}{ BELA VISTA } \\
\hline Ano & Média \\
\hline 1995 & \\
\hline 1996 & $2.455,69$ \\
\hline 1997 & $2.207,39$ \\
\hline 1998 & $2.145,92$ \\
\hline 1999 & $1.252,71$ \\
\hline 2000 & \\
\hline 2001 & \\
\hline 2002 & $1.479,96$ \\
\hline 2003 & $1.923,20$ \\
\hline 2004 & $1.684,02$ \\
\hline 2005 & \\
\hline 2006 & \\
\hline
\end{tabular}

\begin{tabular}{|c|r|}
\hline \multicolumn{2}{|c|}{ HIGIENÓPOLIS } \\
\hline Ano & Média \\
\hline 1995 & $2.518,65$ \\
\hline 1996 & $2.103,08$ \\
\hline 1997 & $2.152,99$ \\
\hline 1998 & $2.603,97$ \\
\hline 1999 & \\
\hline 2000 & \\
\hline 2001 & $1.626,92$ \\
\hline 2002 & $1.812,46$ \\
\hline 2003 & \\
\hline 2004 & \\
\hline 2005 & \\
\hline 2006 & $2.537,08$ \\
\hline
\end{tabular}

\begin{tabular}{|c|c|}
\hline \multicolumn{2}{|c|}{ JARDINS } \\
\hline Ano & \multicolumn{1}{c|}{ Média } \\
\hline 1995 & $2.842,34$ \\
\hline 1996 & $2.594,03$ \\
\hline 1997 & $2.562,09$ \\
\hline 1998 & $2.613,20$ \\
\hline 1999 & \\
\hline 2000 & $2.204,59$ \\
\hline 2001 & $5.559,05$ \\
\hline 2002 & \\
\hline 2003 & $2.564,33$ \\
\hline 2004 & $1.573,05$ \\
\hline 2005 & \\
\hline 2006 & $3.302,32$ \\
\hline
\end{tabular}

\begin{tabular}{|c|c|}
\hline \multicolumn{2}{|c|}{ PARAÍSO } \\
\hline Ano & Média \\
\hline 1995 & $3.416,52$ \\
\hline 1996 & $2.620,41$ \\
\hline 1997 & \\
\hline 1998 & $2.519,89$ \\
\hline 1999 & \\
\hline 2000 & \\
\hline 2001 & $1.519,54$ \\
\hline 2002 & $2.345,42$ \\
\hline 2003 & \\
\hline 2004 & \\
\hline 2005 & $1.845,25$ \\
\hline 2006 & \\
\hline & \\
\hline
\end{tabular}

\begin{tabular}{|c|c|}
\hline \multicolumn{2}{|c|}{ ITAIM $^{2}$} \\
\hline Ano & Média \\
\hline 1995 & $2.297,21$ \\
\hline 1996 & $2.659,31$ \\
\hline 1997 & $2.554,13$ \\
\hline 1998 & $3.129,83$ \\
\hline 1999 & $1.541,38$ \\
\hline 2000 & $2.660,75$ \\
\hline 2001 & $2.225,48$ \\
\hline 2002 & $2.507,96$ \\
\hline 2003 & \\
\hline 2004 & \\
\hline 2005 & \\
\hline 2006 & $5.651,56$ \\
\hline
\end{tabular}

1- Inclui Av. Paulista, trecho da Faria Lima e Av. Rebouças

\begin{tabular}{|c|c|}
\hline \multicolumn{2}{|c|}{ PINHEIROS } \\
\hline Ano & Média \\
\hline 1995 & \\
\hline 1996 & $2.963,44$ \\
\hline 1997 & $2.283,78$ \\
\hline 1998 & $2.213,11$ \\
\hline 1999 & $1.484,04$ \\
\hline 2000 & $1.724,07$ \\
\hline 2001 & \\
\hline 2002 & \\
\hline 2003 & $1.616,66$ \\
\hline 2004 & \\
\hline 2005 & $2.388,25$ \\
\hline 2006 & \\
\hline 3- Inclui trecho da Av. Faria \\
Lima
\end{tabular}

\section{VILA OLÍMPIA}

\begin{tabular}{|c|c|}
\hline Ano & Média \\
\hline 1995 & $2.414,23$ \\
\hline 1996 & $2.543,97$ \\
\hline 1997 & $2.512,85$ \\
\hline 1998 & 2.695,91 \\
\hline 1999 & $1.549,06$ \\
\hline 2000 & $1.789,69$ \\
\hline 2001 & $2.011,99$ \\
\hline 2002 & $1.672,14$ \\
\hline 2003 & $3.496,14$ \\
\hline 2004 & $1.326,29$ \\
\hline 2005 & $2.241,25$ \\
\hline 2006 & $2.508,78$ \\
\hline
\end{tabular}

Lima e Av. JK.

\begin{tabular}{|c|c|}
\hline \multicolumn{2}{|c|}{ BROOKLIN $^{4}$} \\
\hline Ano & Média \\
\hline 1995 & $2.038,85$ \\
\hline \multicolumn{2}{|l|}{1996} \\
\hline \multicolumn{2}{|l|}{1997} \\
\hline 1998 & 2.066,34 \\
\hline \multicolumn{2}{|l|}{1999} \\
\hline \multicolumn{2}{|l|}{2000} \\
\hline \multicolumn{2}{|l|}{2001} \\
\hline \multicolumn{2}{|l|}{2002} \\
\hline 2003 & $1.483,75$ \\
\hline 2004 & $2.084,17$ \\
\hline \multicolumn{2}{|l|}{2005} \\
\hline 2006 & $2.951,19$ \\
\hline \multicolumn{2}{|c|}{$\begin{array}{l}\text { 4- Inclui Av. Luiz Carlos } \\
\text { Berrini }\end{array}$} \\
\hline e Av. Naçõ & \\
\hline
\end{tabular}

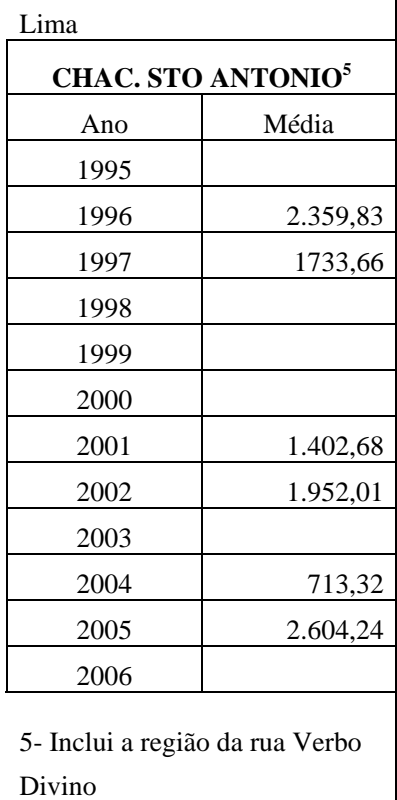


Fonte: Embraesp, 2007

* Preços na época de lançamentos dos imóveis. Não possuem média os anos em que não houve lançamentos.

momento de cada lugar na dinâmica imobiliária do eixo e no movimento próprio da constituição deste eixo.

Dois dados importantes para o mercado imobiliário de edifícios de escritórios são a taxa de vacância, que é a porcentagem de imóveis vazios e a absorção líquida, calculada subtraindo-se do espaço ocupado num dado período o espaço ocupado no período anterior. São esses dois dados que vão revelar para o mercado se este segmento está “em alta” ou não.

Por exemplo, segundo dados da empresa anglo-americana de consultoria Jones Lang LaSalle ${ }^{44}$, a queda da taxa de vacância, que passou de 13,37\% no último semestre de 2006 para 12,37\% no primeiro trimestre de 2007, significa que o mercado está aquecido, pois esse decréscimo representa que menos $\mathrm{m}^{2}$ estão vagos em São Paulo, com relação ao mercado de locação de imóveis comerciais de alto padrão. Segundo Lílian Feng da Jones Lang La Salle, "temos hoje [em São Paulo] ma taxa de vacância muito próxima a do final dos anos 90, época em que o mercado se manteve aquecido em virtude da forte demanda gerada pelas privatizações, pela chegada de novas multinacionais e mesmo pelo boom das empresas telecom.” 45

Outro indicador importante, que do ponto de vista deste segmento indica melhores situações para o mercado ou não, é, como afirmado acima, a absorção líquida que foi de 50 mil m2 no primeiro trimestre de 2007 - 45\% maior em relação ao trimestre anterior e $27 \%$ superior em relação ao primeiro trimestre de 2006. Segundo a empresa Jones Lang LaSalle, as principais taxas de absorção líquidas em São Paulo foram na avenida Paulista 28\%, Berrini 19\% e Vila Olímpia 16\%.

Outro indicador importante é o preço médio do $\mathrm{m}^{2}$ para locação. No primeiro trimestre de 2007, nas regiões nobres o preço do $\mathrm{m}^{2}$ para locação esteve entre $\mathrm{R} \$ 30,00$ e $R$ \$ 95,00; nas regiões secundárias entre $R$ \$25,00 e R\$60,00 e nas áreas alternativas esteve entre $\mathrm{R} \$ 38,00$ a $\mathrm{R} \$ 65,00$.

Para finalizar a exposição desses números, existe hoje em São Paulo um total de 2,1 milhões de $\mathrm{m}^{2}$ de escritórios de alto padrão; um volume de $140 \%$ maior que há dez anos.

\footnotetext{
44 Os dados expostos a seguir foram obtidos no site da empresa Jones Lang LaSalle. www.joneslanglasalle.com.br, acessado no dia 21/05/2007.

${ }^{45}$ Jornal Valor Econômico de 17/05/2007.
} 
"Aquilo que chamamos terra é um elemento da natureza inexplicavelmente entrelaçado com as instituições do homem. Isolá-la e com ela formar um mercado foi o empreendimento mais fantástico dos nossos ancestrais. [...] Imaginar a vida do homem sema terra é o mesmo que imaginá-lo nascendo sem mãos e pés. E no entanto, separar a terra do homem e organizar a sociedade de forma a satisfazer as exigências de um mercado imobiliário foi parte vital do conceito utópico de uma economia de mercado”. (POLANYI, K. “A Grande Transformação", 2000, p. 198). ${ }^{46}$

${ }^{46}$ Citado por CRUZ, 2000, p. 13. 


\section{CAPÍTULO 2}

\section{Os fundos de investimento imobiliário (FIIs)}

A construção e concentração ininterrupta dos edifícios de escritórios no eixo empresarial de São Paulo nos põe diante da idéia de que o capital é por essência circulante. Ao nos referirmos aos edifícios de escritórios, estamos frente a um grande investimento de capital imobilizado no solo urbano, que não se sabe com precisão o tempo de retorno do investimento. Partimos da idéia de que o setor da construção, ligado aos produtos mais modernos, procura com toda intensidade incorporar áreas a partir das quais o processo de construção não cesse, o tempo de rotação do capital seja o menor possível e a rentabilidade imediata seja garantida. Esse movimento nos aponta que “o adensamento da área construída nas áreas centrais da metrópole leva o capital a migrar de uma região para outra em busca de terrenos passíveis de incorporação com lucro" (Carlos, 2001: 90). Estamos diante do fato de que vivemos um momento no qual, do ponto de vista do capitalismo contemporâneo, em tempos de acumulação flexível, a redução do tempo de rotação de capitais exige uma maior velocidade e dinamismo tanto no sistema produtivo, quanto no sistema de circulação de capitais e mercadorias, tomando de assalto também o plano da gestão e coordenação do capital.

Os Fundos de Investimento Imobiliários, entendidos aqui como estratégia para a reprodução do capital, são do ponto de vista dos empreendedores imobiliários e investidores desse mercado, uma modalidade de investimento que combina a solidez do mercado imobiliário com a agilidade e liquidez do mercado financeiro. Neste sentido, traz a mobilidade das transações financeiras ao investimento imobiliário. Estes fundos funcionam nos moldes dos "Real Estate Investment Trusts” americanos. Assim, os fundos de investimentos imobiliários aparecem como um instrumento do mercado de capitais desenvolvido para integrar o mercado imobiliário ao mercado de valores mobiliários, tornando-se um investimento que transforma um ativo imobiliário em financeiro por meio de administração realizada por instituições financeiras.

O investidor compra cotas de um determinado imóvel que está ou será alugado ou vendido, obtendo o rendimento mensal dessa locação sendo que sua administração fica sob responsabilidade das empresas especializadas. Essas cotas podem ser vendidas e compradas em Bolsas, o que pode trazer uma maior liquidez ao investimento imobiliário. 
Esta forma de investimento, que combina segurança e rentabilidade imediata, nada mais nos revela que o capital é necessariamente circulante, tal qual afirmamos anteriormente. E isso não é pouco. Assistimos neste momento do desenvolvimento do capitalismo contemporâneo a uma primazia do plano econômico, dirigido pelo capital financeiro. O sistema financeiro - o capital financeiro - se coloca como uma potência de forças que tende a gerenciar toda a economia, externamente ao circuito da produção, dando aos que controlam estas correntes de investimentos uma posição estratégica na sociedade capitalista (Harvey, 1984). O que percebemos é que o sistema financeiro guarda uma acelerada mobilidade e rentabilidade, trazendo ao mesmo tempo uma vulnerabilidade intensa, riscos de perdas e desvalorizações. Estamos frente a possibilidade do processo de acumulação se realizar com mais rapidez, fluidez e com altíssima rentabilidade num sistema que se encontra fragmentado, descentralizado, ao mesmo tempo que possui uma centralização para que haja a conversão de dinheiro em capital e para a realização da acumulação. O que vai garantir essa centralização são as taxas de juros fixadas pelo Estado, que entra no processo como regulador.

É neste contexto de procura de mobilidade, rentabilidade, valorização e segurança em investimentos que surgem os fundos de investimentos imobiliários. Pois, imobilizar capital é sinônimo de desvalorização do ponto de vista de empresas, especuladores e grandes investidores, porque enfrentam as circunstâncias de flexibilização econômica dada pelo processo de financeirização da economia. Por isso, assistimos à grande busca, principalmente por parte de grandes corporações multinacionais, por escritórios alugados, ou seja, trata-se de uma fuga da desvalorização, de imobilizar capital na compra de imóvel. Por isso, é interessante e vantajoso para os capitalistas que sejam proprietários do capital fixado, imobilizado na terra. Porém, esta situação não se dá sem conflitos entre as partes, pois há uma porção do capital que está imobilizada num lugar, podendo sofrer tanto valorizações como desvalorizações e outra que se encontra livre para mover-se, aproveitando plenamente sua mobilidade potencial. (Harvey, 1984: 395). Mas, para resolver este conflito somente a intensificação da construção de edifícios para escritórios para locação não supera a contradição instaurada. É necessário construir mais, porém a mobilidade de capital e sua rentabilidade se fazem imperativo. É nesse sentido que surge a possibilidade da união do mercado imobiliário com o capital financeiro, não esquecendo a presença da indústria da construção civil, garantindo um investimento seguro e a continuidade do processo de reprodução do capital para investidores. Ainda com relações aos FIIs, faz-se 
necessário descobrir quem são os investidores; porque não investir em fundos de renda fixa, em fundos de ações ou diretamente no mercado financeiro (bolsas de valores); qual o tempo de retorno de um investimento, como os que estão em questão nesta pesquisa; até que ponto esse tipo de fundo imobiliário supera a contradição entre a mobilidade / imobilidade do capital através da (re)produção do espaço urbano em São Paulo ou quais são as novas contradições que daí surgem ou tornam-se mais intensas.

Contudo, observamos que todo esse processo parece ganhar concretude e no espaço da metrópole e este vai sendo (re)produzido no sentido de permitir a acumulação e a reprodução do capital. A constituição deste tipo de fundo de investimento nos revela a participação mais intensa do papel do capital financeiro na produção de novos espaços na metrópole.

A análise desses empreendimentos ainda nos coloca questões sobre o financiamento imobiliário (funding), o setor imobiliário como investimento, a questão da flexibilidade da propriedade do solo urbano, a realização de capitais internacionais, a abertura de capital na bolsa de valores de São Paulo realizada por algumas grandes empresas do setor, a acumulação de capitais realizada por este setor e a compra de terrenos na metrópole, a relação conflituosa entre estes empreendedores e o Estado.

Nas páginas seguintes, encontram uma tabela que traz todos os FIIs em atividade no país, bem como um mapa (mapa 4$)^{47}$ localizando fundos de investimentos imobiliários na Grande São Paulo.

Como nossa pesquisa trata de três FIIs, procuramos analisar os fundos de investimento imobiliário por meio de entrevistas realizadas com pessoas que trabalham diretamente na interface entre o mercado de capitais e o setor imobiliário na cidade de São Paulo. Até o presente momento da pesquisa foram entrevistados quatro executivos, sendo eles: Horácio Kleinmam (Unitas - DTVM ${ }^{48}$ - administrador do FII Continental Square Faria Lima; entrevista concedida em 11/07/2006), Rodrigo Machado (Banco Ourinvest/Brazilian Mortgages - administrador do FII Torre Norte; entrevista concedida em 21/07/2006), Sérgio Belleza Filho (Coinvalores - corretora de valores; entrevista concedida em 26/07/2006), Renato Ventura (Unibanco - administrador do FII Financial Center; entrevista concedida em 26/07/2006). Essas entrevistas foram centrais para o

\footnotetext{
${ }^{47} \mathrm{O}$ mapa apresentado foi elaborado a partir dos FIIs que possuem endereço em São Paulo. Porém, nem todos aparecem no mapa, pois há fundos que congregam diversos imóveis em diversas cidades e não tivemos acesso aos endereços de cada imóvel. Estão representados no mapa fundos que contém de um a dois imóveis em atividade na Grande São Paulo.

${ }^{48}$ DTVM - Distribuidora de Títulos e Valores Mobiliários.
} 
Tabela 7 - Brasil: FIIs Cadastrados na CVM (2007)

\begin{tabular}{|c|c|c|c|c|c|}
\hline $\mathbf{N}^{0}$ & RAZÃO SOCIAL DO FUNDO & ADMINISTRADOR & DATA $^{1}$ & VALOR DO PL ${ }^{2}$ (EM R\$) & $\mathbf{N}^{0}$ DE COTAS \\
\hline 1 & ALDEIA DO VALE FII & RIO BRAVO INVESTMENTOS S.A. DTVM & $31 / 3 / 2007$ & 7.354.518,96 & 1.000 .000 \\
\hline 2 & BB FII PROGRESSIVO & CAIXA ECONOMICA FEDERAL & $31 / 3 / 2007$ & $126.574 .641,00$ & 130.000 \\
\hline 3 & F ALPHAVILLE II & RIO BRAVO INVESTMENTOS S.A. DTVM & $31 / 3 / 2007$ & $15.701 .087,93$ & 1.200 .000 \\
\hline 4 & F BASÍLIO MACHADO II & UNIBANCO UNIAO BANCOS BRAS SA & $28 / 2 / 2007$ & $12.824 .980,32$ & 14.000 .000 \\
\hline 5 & F FINANCIAL CENTER II & UNIBANCO UNIAO BANCOS BRAS SA & $28 / 2 / 2007$ & $24.264 .850,75$ & 38.761 .037 \\
\hline 6 & F FORTALEZA II & RIO BRAVO INVESTMENTOS S.A. DTVM & $31 / 3 / 2007$ & 37.938.579,53 & 500.000 \\
\hline 7 & F JK II & RIO BRAVO INVESTMENTOS S.A. DTVM & $31 / 3 / 2007$ & $24.697 .897,47$ & 26.218 .723 \\
\hline 8 & F SIGMA II & RIO BRAVO INVESTMENTOS S.A. DTVM & $31 / 3 / 2007$ & $12.127 .311,80$ & 80.000 \\
\hline 9 & FII ABC PLAZA SHOPPING & RIO BRAVO INVESTMENTOS S.A. DTVM & $31 / 3 / 2007$ & $52.344 .523,13$ & 40.000 .000 \\
\hline 10 & FII ANCAR IC & BANCO OURINVEST SA & $28 / 2 / 2007$ & $42.411 .882,23$ & 109.117 \\
\hline 11 & FII BCO BBM BARRA FIRST CLASS & BANCO BBM SA & $31 / 3 / 2007$ & $1.642 .542,66$ & 375 \\
\hline 12 & FII C\&D ESTAÇÃO PLAZA SHOW & C \& D DTVM LTDA & $28 / 3 / 2007$ & $5.603 .857,69$ & 73.540 \\
\hline 13 & FII CENTRO TEXTIL INTERNACIONAL & RIO BRAVO INVESTMENTOS S.A. DTVM & $31 / 3 / 2007$ & $40.793 .714,32$ & 36.319 .906 \\
\hline 14 & FII COMERCIAL PROGRESSIVO & BANCO OURINVEST SA & $28 / 2 / 2007$ & $500.300,00$ & 5.000 \\
\hline 15 & FII COMERCIAL PROGRESSIVO II & BANCO OURINVEST SA & $28 / 2 / 2007$ & $204.498 .177,77$ & 2.100 .000 \\
\hline 16 & FII CONTINENTAL SQUARE FARIA LIMA & UNITAS DTVM S.A. & $31 / 3 / 2007$ & $63.523 .304,87$ & 69.033 .500 \\
\hline 17 & FII CR2 JARDIM BOTÂNICO & BANCO CR2 S.A. & $28 / 2 / 2007$ & $4.058 .290,51$ & 35.000 \\
\hline 18 & FII CR2 LARANJEIRAS & BANCO CR2 S.A. & $28 / 2 / 2007$ & $1.603 .951,10$ & 44.720 \\
\hline 19 & FII CR2 RJZ I & BANCO CR2 S.A. & $28 / 2 / 2007$ & $105.682,22$ & 2.880 \\
\hline 20 & FII CR2 RJZ II & BANCO CR2 S.A. & $28 / 2 / 2007$ & $555.116,78$ & 38.400 \\
\hline 21 & FII CR2 RJZ III & BANCO CR2 S.A. & $28 / 2 / 2007$ & $100.290,52$ & 42.000 \\
\hline 22 & FII ED. ALMIRANTE BARROSO & BANCO OURINVEST SA & $28 / 2 / 2007$ & $86.053 .663,81$ & 104.800 \\
\hline 23 & FII EDIFÍCIO OURINVEST & OLIVEIRA TRUST DTVM S.A. & $31 / 3 / 2007$ & 22.236.959,39 & 236.000 \\
\hline 24 & FII EUROPAR & BANIF BANCO DE INVESTIMENTO (BRASIL) S/A & $31 / 3 / 2007$ & 31.127.191,19 & 355.000 \\
\hline 25 & FII FASHION MALL & BANCO OURINVEST SA & $28 / 2 / 2007$ & $9.169 .221,21$ & 110.000 \\
\hline 26 & FII FATOR-RIO OFFICE PARK & BANCO FATOR SA & $31 / 3 / 2007$ & $90.117 .744,03$ & 135.527 \\
\hline 27 & FII FCM & RIO BRAVO INVESTMENTOS S.A. DTVM & $31 / 3 / 2007$ & $-22.451,42$ & 46.971 \\
\hline 28 & FII GAFISA BCO BBM BAY VIEW RES SERV & BANCO BBM SA & $31 / 3 / 2007$ & $958.513,73$ & 840 \\
\hline 29 & FII GAFISA BCO BBM INTERATIVEFLAT & BANCO BBM SA & $31 / 3 / 2007$ & $509.876,67$ & 500 \\
\hline
\end{tabular}




\begin{tabular}{|c|c|c|c|c|c|}
\hline 30 & FII GEO GUARARAPES & BANCO SCHAHIN S/A & $31 / 3 / 2007$ & $4.136 .450,55$ & 12.583 .000 \\
\hline 31 & FII HERMES & RIO BRAVO INVESTMENTOS S.A. DTVM & $31 / 3 / 2007$ & 48.659.069,49 & 54.316 \\
\hline 32 & FII HOSPITAL DA CRIANÇA & BANCO OURINVEST SA & $28 / 2 / 2007$ & $15.562 .106,01$ & 200.000 \\
\hline 33 & FII HYPER I & RIO BRAVO INVESTMENTOS S.A. DTVM & $28 / 2 / 2007$ & $93.761,51$ & 5.000 \\
\hline 34 & FII MANHATTAN & RIO BRAVO INVESTMENTOS S.A. DTVM & $31 / 3 / 2007$ & 20.899.946,86 & 106.700 \\
\hline 35 & FII MEMORIAL OFFICE & COIN - DTVM LTDA. & $28 / 2 / 2007$ & 53.889.217,36 & 508.008 \\
\hline 36 & FII MISTRAL & RIO BRAVO INVESTMENTOS S.A. DTVM & $31 / 3 / 2007$ & $35.736 .358,26$ & 8.703 .994 \\
\hline 37 & FII NOSSA SENHORA DE LOURDES & BANCO OURINVEST SA & $28 / 2 / 2007$ & $57.834 .840,00$ & 600.000 \\
\hline 38 & FII NOVA MORADA & C \& D DTVM LTDA & $28 / 2 / 2007$ & $13.581 .778,72$ & 66.100 \\
\hline 39 & FII PANAMBY & BANCO BRASCAN SA & $31 / 3 / 2007$ & $279.080 .178,88$ & 758.400 \\
\hline 40 & FII PATEO MOINHOS DE VENTOS & RIO BRAVO INVESTMENTOS S.A. DTVM & $31 / 3 / 2007$ & $63.031 .270,40$ & 233.608 \\
\hline 41 & FII PENÍNSULA & BANCO OURINVEST SA & $28 / 2 / 2007$ & $-50.505 .987,33$ & 69.231 \\
\hline 42 & FII PREMIER REALTY & BANCO OURINVEST SA & $28 / 2 / 2007$ & $31.001 .722,98$ & 311.780 \\
\hline 43 & FII PROJ. ÁGUA BRANCA & COIN - DTVM LTDA. & $28 / 2 / 2007$ & 83.111.240,02 & 750.000 \\
\hline 44 & FII PROPERTY & RIO BRAVO INVESTMENTOS S.A. DTVM & $31 / 3 / 2007$ & 23.644.628,70 & 54.000 \\
\hline 45 & FII RB LOGÍSTICA & RIO BRAVO INVESTMENTOS S.A. DTVM & $31 / 3 / 2007$ & $35.498 .986,49$ & 117.127 .515 \\
\hline 46 & FII RIVER SHOPPING & BANCO SCHAHIN S/A & $31 / 3 / 2007$ & 4.035.680,18 & 17.465.039 \\
\hline 47 & FII RODOBENS & BANCO OURINVEST SA & $28 / 2 / 2007$ & 4.304.493,54 & 40.000 \\
\hline 48 & FII SHOPPING PARQUE D. PEDRO & BANCO OURINVEST SA & $28 / 2 / 2007$ & 187.702.701,75 & 1.916 .800 \\
\hline 49 & FII SHOPPING PATIO HIGIENÓPOLIS & RIO BRAVO INVESTMENTOS S.A. DTVM & $31 / 3 / 2007$ & 72.233.589,11 & 400.000 \\
\hline 50 & FII SUPERQUDRA 311 NORTE & RIO BRAVO INVESTMENTOS S.A. DTVM & $31 / 3 / 2007$ & 4.401.850,09 & 279.872 \\
\hline 51 & FII TORRE ALMIRANTE & BANCO OURINVEST SA & $28 / 2 / 2007$ & $95.843 .073,45$ & 104.700 \\
\hline 52 & FII TORRE NORTE & BANCO OURINVEST SA & $28 / 2 / 2007$ & $312.527 .952,81$ & 3.935 .562 \\
\hline 53 & FII TRADE CENTER & BANCO OPPORTUNITY SA & $31 / 3 / 2007$ & 42.162.449,66 & 42.632 \\
\hline 54 & FII TROPICAL & RIO BRAVO INVESTMENTOS S.A. DTVM & $31 / 3 / 2007$ & $14.539 .973,10$ & 20.041 .000 \\
\hline 55 & FII VIA PARQUE SHOPPING & RIO BRAVO INVESTMENTOS S.A. DTVM & $31 / 3 / 2007$ & $51.165 .150,34$ & 2.120 .589 \\
\hline 56 & FII VILLE DE FRANCE & RIO BRAVO INVESTMENTOS S.A. DTVM & $28 / 2 / 2007$ & 3.795.326,15 & 1.200 \\
\hline 57 & FP F ANDROMEDA FII & COINVALORES CCVM LTDA & $28 / 2 / 2007$ & 81.195.967,62 & 880.000 \\
\hline 58 & GUANABARA FII & RIO BRAVO INVESTMENTOS S.A. DTVM & $31 / 3 / 2007$ & 4.583.210,33 & 3.000 \\
\hline 59 & HG BRASIL SHOPPING FII & HEDGING-GRIFFO CV SA & $31 / 3 / 2007$ & $60.329 .414,45$ & 60.000 \\
\hline 60 & LAGRA FII & MOMENTO DTVM LTDA & $31 / 3 / 2007$ & $114.680 .983,59$ & 56.701 \\
\hline 61 & LOGINVEST FII INDUSTRIAL & RIO BRAVO INVESTMENTOS S.A. DTVM & $31 / 3 / 2007$ & 33.153.264,65 & 17.100 \\
\hline
\end{tabular}




\begin{tabular}{|r|l|l|r|r|r|}
62 & MINAS INDUSTRIAL FII & RIO BRAVO INVESTMENTOS S.A. DTVM & $31 / 3 / 2007$ & $96.294 .026,61$ & 5.301 .000 \\
\hline 63 & SC FII & BANCO SCHAHIN S/A & $28 / 2 / 2007$ & $39.904 .359,00$ & 14.475 \\
\hline 64 & SCP FII & UNITAS DTVM S.A. & $28 / 2 / 2007$ & $25.143 .977,93$ & 4.200 .000 \\
\hline & & TOTAL & & $\mathbf{2 . 8 8 2 . 6 2 9 . 2 3 3 , 4 3}$ & \\
\hline
\end{tabular}

Fonte: Cadastro de Patrimônio Líquido de Fundos de Investimento Imobiliário, CVM, 2007. (site: www.cvm.gov.br acessado em 13/04/2007).

1- Data da última atualização dos dados disponíveis na CVM.

2- PL: Patrimônio Líquido

FIIs com cotas negociadas na BOVESPA (www.bovespa.com.br acessado em 14/04/2007).

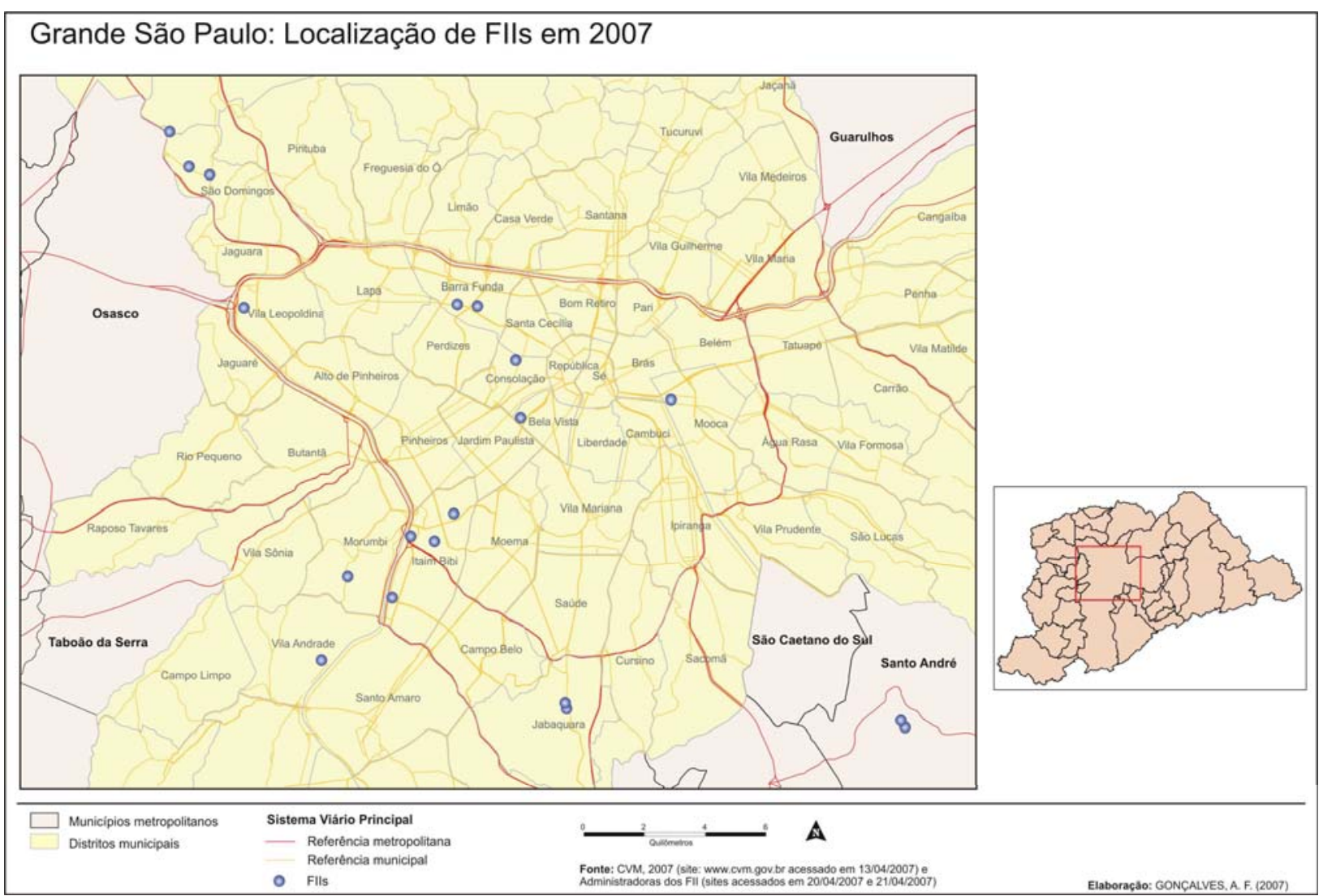


aprimoramento de nossa compreensão sobre o que vem a ser um FII e sua realização no contexto da economia financeira da metrópole.

Os FIIs surgem no Brasil em 1993 com a lei de número 8.668, que teve sua primeira regulamentação realizada pela CVM (Comissão de Valores Mobiliários) na instrução 205 e 206 de janeiro de 1994. Tratava-se de um momento no qual havia dificuldade de financiamento imobiliário no país, agravado pela extinção do BNH. Existia um déficit de recursos para financiamento da produção imobiliária no Brasil. Havia uma necessidade de funding ${ }^{49}$ para o setor imobiliário. Machado explica como os fundos aparecem no Brasil:

“O BNH estava quebrado, é o único mecanismo de financiamento, então foi se buscar no mundo o que estava sendo feito como solução alternativa de funding para produção imobiliária. Então os fundos estavam certamente deslanchando nos países mais maduros, especialmente os EUA, e com isso eles trouxeram de lá o conceito do fundo imobiliário que era nada mais do que transformar num valor mobiliário livremente negociado no mercado de capitais, que é um mercado mais líquido, um mercado mais maduro, um mercado transparente, é onde tem uma abundância maior de recursos, então transformar um projeto imobiliário num valor mobiliário livremente negociado nesse mercado de tal maneira que você conseguisse reunir investidores de capital de risco, não era empréstimo, não era dívida, para desenvolver projetos imobiliários de rentabilidade a partir de então. E isso só seria possível com a criação de estruturas como essa”.

Continuando seu raciocínio, revela os sujeitos envolvidos neste processo:

“Então na ocasião essa era a conjuntura que fez com que o governo se movimentasse junto com o Secovi e outras entidades de classe que estavam intimamente ligadas com o setor para que se buscasse alternativas de funding para o setor imobiliário que não tinha recursos disponíveis ... Então foi montado esse grupo que trabalhou junto ao Congresso pra elaborar a lei

\footnotetext{
${ }^{49}$ Funding - Palavra inglesa incorporada ao vocabulário dos agentes desse setor para designar recursos financeiros disponíveis para financiamento. No contexto dos FIIs significa, de acordo com Ventura, "uma maior quantidade de fundos disponíveis e preço mais barato, já que com uma competição maior de fundos querendo investir ele pode conseguir fundos mais baratos que se traduz num imóvel mais barato também, se o custo do dinheiro é menor, o imóvel pode ficar mais barato".
} 
8.668/93 e foi aprovada e foi regulamentada pela CVM através das instruções 205 e 206 de 1994”.

Cada um dos entrevistados define FII de maneiras diferentes, porém complementares. Segundo Kleinmam, o FII não é outra coisa que uma maneira de securitizar ativos; associar um título a um ativo. Associa-se ao ativo imobiliário, que neste momento está sendo objeto do fundo, um título, que é uma cota colocada no mercado, seja institucional, seja de varejo. Ainda segunda Kleinmam pode-se securitizar todos os ativos que você possa imaginar, bastam que tenham rendas homogêneas e contínuas.

Ventura, por sua vez, define FII como sendo:

"um instrumento de pulverização de participação de investidores em empreendimentos imobiliários. Eu acho que ele trouxe um investidor... Alguém que gostasse de negócios imobiliários estava, até o surgimento dos fundos, fadado, digamos assim, a investir comprando imóveis. O fundo foi algo que veio trazendo uma possibilidade de pulverização maior desses investimentos e acho que os edifícios comerciais são emblemáticos sobre isso, para você comprar um andar num edifício comercial é uma montanha de dinheiro, se você não tem uma montanha de dinheiro, você pode comprar uma cota ou um volume de cotas de um fundo imobiliário e você vai ser dono de uma parte daquele andar de um edifício comercial de alto padrão que você não poderia ter acesso. Então ele permitiu que você tivesse acesso a outras formas de imóveis, de outras formas de participação. Eu acho que a criação deles, dos fundos, veio da percepção, da necessidade de se ter mais instrumentos mesmo de capital, de se buscar capital pra "fundiar" investimentos imobiliários, acho que foi uma percepção advinda até da comparação com outros países em que se têm outras formas, formas mais sofisticadas de se juntar desejos de investimentos com necessidades de novas construções, novos empreendimentos e tudo mais, então se foi buscar um pouco alguma inspiração em outros lugares e se viu que existem outras formas e se buscou trazê-las para cá, acho que o fundo partiu disso, nesse primeiro momento disso ... O fundo, do ponto de vista financeiro, junta determinadas propriedades ou uma propriedade, ele compra essa propriedade que passa a ficar em nome do fundo, administrado pelo administrador e tudo mais e o que esse administrador, esse fundo faz? Ele 
vai ter receitas, despesas, vai ter um fluxo de caixa, que ele vai distribuir o fluxo de caixa para os compradores das cotas. Então tudo que tenha um determinado fluxo de caixa é passível de virar um fundo.

Observamos nesta fala que Ventura, ao definir o que é FII, revela dois elementos de destaque em um FII. Segundo ele, de um lado, o fundo oferece aos investidores (dando destaque ao pequeno e médio) a possibilidade de investir capital no setor imobiliário e de ser dono de um empreendimento de alto padrão que possua localização privilegiada na cidade, e de outro, o fundo se revela como um instrumento passível de absorver recursos financeiros para o setor imobiliário. Um ponto de contato com a fala de Kleinmam, anteriormente citada, é justamente a possibilidade de securitizar vários ativos que apresentam fluxo de caixa. Outro elemento central para nossa análise é a pulverização de participação dos investidores em negócios imobiliários como este. Segundo Ventura:

"pulverizar é dar acesso a mais gente para aquele tipo de investimento. Pulverizando você incentiva sim a liquidez. O que significa pulverizar? Pulverizar significa ampliar o universo de gente que tem acesso àquele investimento. Enquanto, pensando em edifícios de escritórios, você tinha um certo números de investidores que podiam comprar aquilo, na hora que você pode estruturar um fundo imobiliário você amplia aqueles investidores, você está ampliando esse universo, então você está incentivando a liquidez mesmo nesse mercado específico, você está aumentando os possíveis compradores, os possíveis interessados nesse tipo de investimento. Então você está ampliando a liquidez, você está ampliando o universo de transações possíveis, então acho que essa é a importância, além de ampliar o universo, você está dando acesso a pessoas que não tinham acesso àquele tipo de oportunidade ... ele [o mercado imobiliário] aumentou [com a pulverização] o universo de possíveis fontes de funding de dinheiro para botar em pé o seu empreendimento”.

No mesmo sentido, Kleinmam, ao apontar vantagens e desvantagens de participar de um investimento como um fundo, toca nas mesmas questões apresentadas por Ventura na fala acima, tais como: a importância de oferecer este investimento a um número cada vez maior de pessoas, o que incentivaria a liquidez das cotas; oferecer a 
possibilidade de investimento ao pequeno e médio investidor de possuir "propriedade" em edifícios de alto padrão em lugares valorizados da cidade; aumentar as possibilidades de financiamento (o que eles chamam de funding). Afirma Kleinmam:

"Você, por exemplo, nunca poderia imaginar que você vai poder ser dono de um andar de $1.800 \mathrm{~m}^{2}$, onde você estará alugando para uma grande empresa multinacional auferindo em conseqüência uma renda que só estava reservada aos grandes investidores. Só que aqui você pode comprar $\mathrm{R} \$ 10$ mil de títulos e proporcional a esses $\mathrm{R} \$ 10$ mil você vai ter a mesma renda que teria o grandão que teria comprado aquele imóvel inteiro para alugar para as grandes. Então é uma maneira também de democratizar o acesso dos investidores de diversas possibilidades aos grandes empreendimentos ... Uma desvantagem do FII é que ele tem que ser necessariamente administrado por uma instituição financeira, caso a Unitas. Isso significa que o cotista não tem a governança do assunto, quem tem a governança é o administrador em nome do cotista, tem que fazer assembléia, os cotistas têm que votar as coisas, mas ele não está diretamente vinculado ao produto, então o que acontece? Se amanhã uma assembléia decide que vai dar de presente esse bem para quem quer que seja e a maioria decidiu que sim e você não queria, você está atrelado àquela decisão da maioria. Então a governança é uma das diferenças fundamentais na securitização via um FII, que não está em mão do cotista, mas está em mão de uma instituição financeira que administra o fundo em nome dos cotistas”.

Ainda segundo Ventura, há uma inspiração dos FIIs brasileiros nos REITs americanos, os Real Estate Investment Trusts, que também são instrumentos de participação de equity ${ }^{50}$. Os investimentos como os REITs americanos são negócios mais móveis, enquanto os fundos brasileiros se voltam para imóveis específicos (compra-se um imóvel ou parte dele e participase da renda que este imóvel dará). Nos REITs, por exemplo, compra-se uma cota de uma empresa e essa empresa comprará e venderá imóveis, recebendo assim o cotista a rentabilidade referente a estas transações imobiliárias; então a sua cota não está ligada a um determinado imóvel. Os REITs também podem ser setoriais, existindo, por exemplo, REIT que somente

\footnotetext{
${ }^{50}$ Equity diz respeito a investir capital em algum negócio, portanto se contrapondo a dívida. Equity significa pôr dinheiro no negócio e esperar o dinheiro voltar sem remuneração combinada (para mais ou para menos, relativo ao montante investido). Já num financiamento aplica-se o dinheiro esperando os juros. Equity é passar a ter participação em um negócio. Pode-se participar de um empreendimento imobiliário sendo dono dele (equity) ou sendo financiador (bancos), que no caso torna-se credor, em forma de dívida.
} 
compra e vende shopping centers na costa leste dos Estados Unidos. Neste país também é permitida a existência de fundos de investimento imobiliário cujo bem imóvel seja de uso residencial. A regulamentação americana para este tipo de empreendimento só atua sobre a distribuição dos rendimentos entre os cotistas dos fundos. Já no Brasil, a legislação incide sobre todas as etapas da estruturação e funcionamento de um FII. De acordo com Belleza o mercado americano tem 30, 40 anos e os REITs encontram-se completamente desenvolvidos naquele país. Existem hoje nos Estados Unidos US\$300 bilhões de patrimônio em FIIs que são publicamente negociados - o maior fundo de investimento imobiliário investe em escritórios e tem um patrimônio aproximado de US\$17 bilhões. Sobre este assunto Belleza afirma:

"Os fundos americanos têm mais cara de fundos mesmo, são fundos que tem vários imóveis. A diferença fundamental entre o FII americano e FII brasileiro é que nós aqui somos um fundo que tem que ter uma instituição financeira como administradora e lá é uma empresa, lá o fundo pode inclusive pegar dinheiro emprestado, o nosso não pode, lá o fundo pode ter empregados, uma diretoria. O FII aqui não tem nem personalidade jurídica, ele é como qualquer outra conta de fundo de investimento. Essa foi a forma mais fácil de poder dar pra ele as vantagens tributárias que ele tem; só tem imposto na hora que distribui os rendimentos para os cotistas e se for pessoas física dentro da regra nova tem isenção de imposto de renda”.

Belleza, ao apresentar o que pensa ser um fundo de investimento imobiliário, afirma que:

“O FII é uma comunhão de recursos de investidores pra se investir na área imobiliária. Essa comunhão de recursos é organizada através da operação de um fundo de investimento normatizada e regulada pela CVM (Comissão de Valores Mobiliários), já que é uma captação de recurso do público. O FII é conhecido como um fundo fechado, isto quer dizer, um fundo que não tem resgate de cotas, diferente dos fundos mais conhecidos que são os fundos de ação de renda fixa, em que você tem regras de movimentação, ou seja, você colocou o seu dinheiro, depois tem uma regra, dependendo de cada fundo, de como você recupera o seu capital, em que prazo você pode resgatar. $\mathbf{O}$ FII é exatamente igual a uma ação de uma empresa, porque da mesma forma que você não pode ir à Petrobrás e falar "me dá meu dinheiro de volta” e levar sua ações da Petrobrás, você tem que vender pra alguém, da 
mesma forma um FII você tem que vender para alguém. Portanto nada mais natural do que haver um mercado secundário organizado, forte e bem regulado que só um negócio em bolsa de valores pode proporcionar”.

Observamos que Belleza destaca em sua fala os seguintes pontos: a necessidade de haver um grupo de investidores que direcione o seu investimento para o setor imobiliário; o papel da regulação e normatização do Estado na figura da CVM; a questão do fundo ser fechado, não havendo possibilidade de resgate de cotas, que para fazê-lo é necessário vender cotas; a analogia entre fundos e ações de uma empresa, apontando já para o debate da mobilidade trazida pelo mercado de capitais; mercado secundário organizado como a Bovespa torna-se um elemento importante no sentido de alcançar maior liquidez.

Belleza também dá destaque, como os outros entrevistados, quando aludem a respeito do contexto do início dos anos 1990, momento em que surgem os fundos no Brasil, para a questão da dificuldade de se levantar recursos no mercado para a produção imobiliária e ainda afirma:

\footnotetext{
"quando começou a utilização do fundo imobiliário, você imagina a dificuldade que foi, porque exatamente em 94/95 o mercado de escritório estava numa época de baixa muito grande, historicamente nós estávamos vivendo um período de aluguel baixo e uma oferta maior de escritórios, portanto estava difícil”.
}

O sentido desta afirmação de Belleza torna-se importante pelo fato de destacar como dificuldade a baixa em que se encontrava o mercado de escritório em São Paulo nos anos iniciais de operação dos fundos e um período de aluguel também baixo. O primeiro ponto pode ser relacionado à importância central que os edifícios de escritórios possuíam/possuem para a realização de fundos de investimento imobiliário. O segundo trata-se de elemento fundamental para a rentabilidade do fundo, a qual provém da locação imobiliária.

Os fundos imobiliários, como podemos observar, varia pelo tipo de atividade e uso que se desenvolverá no imóvel objeto do fundo. Por exemplo, um FII como o Almirante Barroso, localizado no Rio de Janeiro, que tem um único imóvel locado para a Caixa Econômica Federal depende de um pagamento de aluguel praticamente 
conhecido. O resultado a ser distribuído é praticamente conhecido, pois será o total arrecadado com o aluguel subtraindo-se as despesas do mês e se não houver nenhum investimento de ordem de infra-estrutura e de manutenção do edifício, a distribuição dos rendimentos desses tipos fundos tendem a ser linear. Já, por exemplo, o FII Shopping Pátio Higienópolis, que é dono de 25\% do shopping, possui uma rentabilidade menos linear, pois o aluguel no shopping center tem relação com as vendas. Por exemplo, na época de Natal em que as vendas aumentam, haverá meses como janeiro, fevereiro que refletem o mês de Natal, que possuirá maior rentabilidade como conseqüência do aumento das vendas; e também existe o piso mínimo cobrado em dobro nessa época do ano, o chamado de $13^{\circ}$ aluguel. A rentabilidade de um fundo que tem como patrimônio um shopping (seja 100\% ou uma parcela menor) pode ter cada mês um valor diferente, porque as áreas destinadas à locação em um shopping podem ser alugadas pelos lojistas por um valor mínimo por $\mathrm{m}^{2}$ e por um percentual sobre o faturamento dos meses em que este for maior. Portanto, se se trata de um mês bom de vendas o fundo oferece maior rentabilidade, uma remuneração melhor. Sobre esse tipo de fundo Belleza afirma:

\begin{abstract}
"O negócio de investimento em FII ligado a shopping center traz muito mais emoção em termos de desempenho, está muito mais atrelado ao desempenho do comércio varejista e da atividade daquele empreendimento, como ele está sendo administrado, localização. E o FII como Almirante Barroso é muito mais para um investidor conservador”.
\end{abstract}

Os fundos de loteamento vivem de resultados, eles não se realizam distribuindo renda, além do que tem um tempo para que seja encerado. Trata-se de um fundo que vai comprar uma área, vai aplicar o dinheiro dos investidores para comprar a área, fazer a urbanização, colocar para vender e retorna os resultados aos cotistas, é fundo que especula na compra, “beneficiamento” e venda, como é o caso do Panamby. E por fim os fundos de armazém, como o Europar, possuem um funcionamento parecido a fundos de grandes prédios de escritórios. De acordo com Kleinmam, um fundo que tem por patrimônio um imóvel construído tem um cálculo feito de 20 anos de operação e mais 20 anos de exaustão. Então estrutura-se um fundo pensando a longo prazo, em 40, 50 anos de atividade. Enquanto que em um fundo como o Panamby (terrenos) há um determinado momento em que a venda total é feita e o fundo é encerrado. 
Fix (2003: 42), afirma que há dois tipos de fundos, os de renda e os de incorporação. Os fundos de renda são aqueles que possuem o imóvel que vai gerar renda contínua para os investidores (shoppings, hospitais, armazéns, edifícios corporativos de escritórios) e os de incorporação são os que chamamos anteriormente de loteamento. Trata-se da venda do produto final, loteamento, terrenos, como o Pananby.

Inicialmente, os fundos de investimento imobiliário teriam um objetivo primeiro de angariar recursos financeiros para a produção imobiliária de diversos tipos de construção, ou seja, através da reunião de diferentes capitais, construir imóveis num ritmo cada vez maior. Isto requer uma grande quantidade de capitais diversos injetado nesse setor, ou seja, a partir de um fundo de investimento imobiliário construir outros imóveis que também seriam da carteira do fundo ou transformados em outros fundos e que também iriam se financiando porque seriam passíveis de absorção de capitais. Entretanto, hoje, os fundos imobiliários no Brasil, conforme afirmam os entrevistados, ainda estão restritos à venda de imóveis (tornar o imóvel pronto, parte dele ou em sua totalidade, num FII) e projetos imobiliários e ainda não possuem um movimento interno de reprodução do próprio fundo o que criaria a possibilidade de um ciclo contínuo de construção (tanto interno a um fundo específico como a criação de outros fundos e a articulação entre fundos). No momento atual, os fundos têm tido como patrimônio apenas um imóvel ou parte de um imóvel e os investidores cotistas têm o direito do rendimento que provêm do aluguel proporcional à quantidade de cotas adquiridas. A porcentagem que o fundo guarda para si como fundo de reserva só pode ser aplicado em renda fixa, conforme a legislação em vigor no país. Isto mostra que cada fundo existe a partir de um ativo imobiliário, não havendo possibilidade deste fundo proporcionar uma real captação de recursos para construção de outros empreendimentos imobiliários, o que vai revelar que o instrumento no Brasil está, ainda, no plano das vendas de cotas de imóveis. Em países como Estados Unidos e Portugal, a movimentação financeira realizada pelos fundos é suficientemente grande para que este instrumento torne-se uma forma real de captar capitais para a produção imobiliária de forma contínua e cada vez maior. Entretanto no Brasil, observamos um movimento de tendência nesse sentido, ou seja, do fundo ser um instrumento real de captação de recursos para financiamento imobiliário.

As fases por que passaram os FIIs no Brasil, e especificamente na cidade de São Paulo, podem ser reveladoras de estratégias tomadas pelos empreendedores deste ramo para sua realização, bem como para nos indicar novos elementos para a análise e 
reforçar o que já apontamos anteriormente. O que aqui chamamos de fases são diferentes períodos nos quais certas características de realização deste instrumento são predominantes e ao mesmo tempo novas. O funcionamento dos fundos está condicionado à recriação contínua de estratégias que vão direcionar o mercado, sendo gradativamente nele incorporado. Essas fases são designadas pelos entrevistados como “ondas”. Pensamos que tal termo é assim empregado pelo fato do fundo se tratar de um mecanismo que possui, no movimento de seu desenvolvimento, altos e baixos, que derivam de uma série de condições macro-econômicas nacionais e internacionais (política econômica, estabilidade monetária, taxa de juros, etc), assim como da regulamentação realizada pelo Estado em seus diversos níveis e instituições. A designação onda talvez seja utilizada em razão das características cíclicas do mercado. Em nossa pesquisa utilizaremos a palavra fase.

A primeira fase foi marcada pela introdução dos FIIs como veículos fiscalmente eficientes. Segundo Machado, os fundos não eram usados para atrair investidores, mas para "vestir" um empreendimento em que eles já tinham os investidores identificados para realizar determinados empreendimentos imobiliários. Esta fase foi caracterizada por pequenos empreendimentos. Trata-se de um momento de liberar os investidores dos FIIs do pagamento de impostos sobre o patrimônio securitizado. Segundo Botelho (2005: 159), “muito dos primeiros FIIs foram utilizados inicialmente como forma de reduzir a carga de impostos pagos e não como elementos para captar recursos para a produção imobiliária”. De acordo com Regis Dallagnese ${ }^{51}$, a primeira fase também teve como característica o seguinte:

\begin{abstract}
“Todos os primeiros fundos imobiliários foram constituídos simplesmente como uma forma de gerenciamento de patrimônio. Você tinha um construtor, um investidor, um incorporador que tinha um grande patrimônio imobiliário e que vê no FII um bom veículo para obter alguns benefícios fiscais, e então eles começaram a colocar o seu patrimônio imobiliário dentro dos fundos imobiliários. Existia um grande atrativo que era o fato dos fundos não serem obrigados a distribuir, na prática, os resultados, e hoje a legislação não prevê a obrigatoriedade de eles distribuírem resultados. No
\end{abstract}

\footnotetext{
${ }^{51}$ Gerente de estruturação de fundos de investimento imobiliário da empresa Rio Bravo Securitização S/A. Entrevista concedida a Adriano Botelho em 15/05/2002. In: BOTELHO, Adriano. "O Financiamento e a Financeirização do Setor Imobiliário: uma análise da produção do espaço e da segregação sócioespacial através do estudo do mercado da moradia na cidade de São Paulo”. Tese de Doutorado, Departamento de Geografia, FFLCH, USP, São Paulo, 2005. p.158.
} 
passado, no início de 1993 até 1995, não existia obrigatoriedade nenhuma de se distribuir os resultados, então se colocava o patrimônio imobiliário dentro do Fundo, ia girando aquilo, nunca distribuía resultados, então a renda, por exemplo, gerada com a locação de um imóvel você comprava um outro e assim por diante. Na prática você nunca distribuía os resultados e o fundo não tinha tributação nenhuma. Era uma grande jogada para este tipo de investidor. Então, não era na prática uma fonte de captação de poupança, mas muito mais para gerenciamento de patrimônio". ${ }^{52}$

Pedro Klumb ${ }^{53}$ revela em sua fala o que aconteceu no final desta primeira fase. Esta transformação abrirá o caminho para a segunda fase dos FIIs sobre a qual discorreremos em seguida.

\begin{abstract}
"Os fundos tinham uma vantagem fiscal tão grande - não pagavam imposto, não pagavam PIS, COFINS, etc. - , que os incorporadores, os empreendedores, pensaram o seguinte: 'eu vou colocar a minha estrutura produtiva dentro do fundo, enquanto eu não precisar sacar esse recurso, eu tenho isenção fiscal'. O incorporador poderia, nessa estrutura, fazer quatro projetos ao invés de três com o mesmo recurso. Em 1997, a Receita Federal acabou com essas isenções. A onda não acabou em 1997, ela prosseguiu até 1998, mas a partir de 1997 muitos fundos começaram a sair. Em 1998, mudou as regras de novo, porque ela ficou tão rígida em 1997 que inviabilizou o mercado de fundos”.
\end{abstract}

Para nosso debate, Machado inclui, em sua fala sobre a transição da primeira fase a segunda fase dos FIIs, um raciocínio interessante sobre o processo de amadurecimento desses fundos de investimento, o que pode mostrar que é necessário para realização desses empreendimentos que eles sejam implantados aos poucos num movimento em que se destacam as particularidades dos lugares onde são implantados. Então retomando o que marca a primeira fase do fundo, um veículo fiscalmente eficiente, ele diz:

\footnotetext{
${ }^{52}$ Grifo nosso.

${ }^{53}$ Presidente da SFI (Serviços Financeiros Imobiliários). Entrevista concedida a Adriano Botelho em 17/09/2002. In: BOTELHO, Adriano. "O Financiamento e a Financeirização do Setor Imobiliário: uma análise da produção do espaço e da segregação sócio-espacial através do estudo do mercado da moradia na cidade de São Paulo”. Tese de Doutorado, Departamento de Geografia, FFLCH, USP, São Paulo, 2005. pp. 158-159.
} 
“a gente sabia que isso fazia parte de um movimento, assim como aconteceu nos EUA, de um processo de amadurecimento; se eu começar por aí, instrumento, vou criando um histórico e à medida que o tempo vai passando os fundos vão crescendo vão se tornando nacionais. Mas aí alguns bancos começaram a usar mal esse recurso e fizeram então uma mudança na legislação no final de 97, que praticamente matou os fundos. Foi criada uma regra pra evitar isenção fiscal aqui e quase mataram os fundos... Mais ou menos nesse meio tempo a gente estava vivenciando o início da segunda onda que é a entrada dos fundos de pensão nesses fundos...”

A segunda fase é marcada pela presença maciça dos fundos de pensão ${ }^{54}$ neste mercado. Neste período, eles podiam ter cerca de 25\% de seu patrimônio alocados em negócios imobiliários. Machado diz que no final dos anos 1990, a Secretaria de Previdência Complementar, que é o órgão que regula e que fiscaliza os fundos fechados de previdência privada ligada ao Ministério da Previdência instituiu uma norma proibindo que os fundos fechados de previdência privada participassem de incorporações imobiliárias. Com isso, os fundos que aplicavam na área imobiliária passam aplicar em FIIs. Entretanto, a Secretaria passa a entender que as cotas de FII estão envolvidas dentro desse limite que os fundos de pensão têm para investir em negócios imobiliários, ou seja, a instituição que legisla sobre os fundos de pensão fechados colocou cotas de FII junto no segmento de imóveis. Sobre isso Machado afirma que "imóveis eram uma coisa, fundo imobiliário era outra; tinha um limite de imóveis para eles investirem, aí eles misturaram tudo lá e diminuíram esse limite”. O limite de recurso a ser investido em imóveis por parte dos fundos de pensão foi diminuindo - hoje está em 11\% e tende até 2008 chegar a 8\%. Sobre a diminuição da porcentagem que os fundos de pensão podem investir em imóveis, Belleza afirma:

"Eu acho que está completamente equivocado você ter um investimento em fundo de investimento imobiliário dentro de um limite imobiliário. Nós não somos um investimento imobiliário, nós somos um investimento mobiliário de lastro imobiliário. É muito diferente você comparar o

\footnotetext{
${ }^{54}$ Em realidade, não há uma separação exata entre uma fase e outra com relação à participação dos fundos de pensão, pois, segundo Belleza, tais fundos participam deste mercado desde 1994 e tiveram papel marcante, segundo o mesmo entrevistado, até 1999, quando se inicia o que se chama de terceira "onda".
} 
investimento da Previ no projeto Sauípe e o investimento da fundação FUNCEF na Torre Norte que é FII hoje. A FUNCEF como dona de mais de 80\% do edifício Torre Norte pode vender sossegada pedaços disso a hora que ela quiser. A Previ com a propriedade que ela tem do Sauípe dificilmente ele conseguiria vender pedaços de sua escritura ou da empresa que ela tem lá. Os números do Torre Norte, do qual a FUNCEF é grande acionista, sai todo mês no site da CVM. Os números do Sauípe provavelmente é difícil de encontrar. O investidor que compra cotas do Torre Norte hoje, pessoa física, o rendimento que ele receber é isento de imposto de renda. Eu considero, portanto, que a Secretaria de Previdência Complementar não tem entendido, ela fomenta, mas eu percebo que ela fomenta, ela deveria entre as atitudes que ela tem que tomar pra fomentar os fundos de pensão a atuar nos FII de forma organizada é tirar fora dos limites imobiliários os negócios com FII. Obviamente dentro de algumas condições, desde que esse fundo seja negociado em bolsa”.

A afirmação de Belleza sobre o FII como investimento mobiliário com lastro imobiliário é característico do discurso dos profissionais que trabalham com FIIs. Ventura diz que o fundo

\begin{abstract}
"Seria um investimento que tem um imóvel por traz que gere alguma renda e o investimento financeiro é a apropriação dessa renda, é financeiro porque você está olhando a renda que aquele imóvel vai dar. Ele é financeiro porque é um papel que dá direito a determinada renda, por isso é um instrumento financeiro. Ele é mais financeiro que imobiliário. Ele é um instrumento financeiro com lastro imobiliário, um instrumento financeiro”.
\end{abstract}

Acrescentando mais informações, Belleza afirma que o fundo de investimento imobiliário é:

\footnotetext{
“a junção das melhores coisas do setor imobiliário e das melhores coisas do setor mobiliário. O que o imobiliário tem de bom? O lastro, a segurança, do chão eu não passo, a tradição. E o que ele tem de ruim? A baixíssima liquidez, a pouca transparência, a pouca forma de você fazer comparações, a pouca divisibilidade, muita burocracia. Agora vamos para o mercado mobiliário. O que o mercado mobiliário traz de vantagem? Mobilidade, o
} 
ambiente de negociação, a transparência, a regulamentação e as fiscalizações dos órgãos governamentais, a possibilidade de oferecer isso a investidores de qualquer lugar do mundo, a capilaridade da distribuição que você pode conseguir através do mercado de capitais. Se você juntar esses dois pontos você consegue superar esses defeitos, vamos chamar assim, as deficiências que o investimento imobiliário tem trazendo mobilidade, transparência”.

Esses fragmentos da fala de Belleza expõem diversos elementos que estamos considerando centrais em nossa análise. Fica evidente a contradição entre mobilidade e imobilidade e a questão da liquidez, fundamental para que a mobilidade do imobiliário seja alcançada; o que para acontecer depende de algumas estratégias e características do mercado. O que pode nos revelar que o processo não se realiza livremente sem barreiras. Assim, para que haja mobilidade é preciso que exista liquidez como condição dessa mobilidade. Belleza para sustentar seu argumento de que o FII é um investimento mobiliário com lastro imobiliário, que une mobilidade do mercado de capitais e a segurança do imobiliário e que é um instrumento que depende da liquidez para se realizar, dá como exemplo o caso do FII Almirante Barroso da Caixa Econômica Federal, localizado na cidade do Rio de Janeiro.

Segundo Belleza, o FII Almirante Barroso, estruturado em 2003, trouxe pela primeira vez uma grande instituição de varejo (um banco de varejo) que é o caso da Caixa Econômica Federal. Esta instituição fez um negócio no qual ela estruturou um fundo imobiliário através de seu imóvel mais importante no Rio de Janeiro, tornando-se inquilina do imóvel de R $\$ 104.800$ milhões. A caixa vendeu através de suas agências bancárias cotas que valiam R \$1 mil (portanto um investimento a partir deste valor), atingindo um público de cerca de 5.200 investidores e um ticket manager ${ }^{55}$ entre R\$19 mil e R\$20 mil, o que significa que na média cada investidor comprou por volta de R\$20 mil. O que mostra, segundo Belleza, uma grande pulverização.

A análise que Belleza faz a partir desse exemplo é que se trata de uma operação boa para os dois lados (o inquilino, no caso a própria Caixa que deixou de ser proprietária de um grande imóvel que significa capital imobilizado e os mais de cinco mil investidores):

\footnotetext{
${ }^{55}$ Valor da venda dividido pelo número de pessoas que entrou no fundo.
} 
"porque se por um lado a Caixa Econômica está fazendo dinheiro, que é a mercadoria que o banco tem que ter na prateleira e não é tijolo, pra eles interessa sem dúvida nenhuma vender um imóvel e virar o inquilino porque, pra simplificar, está captando recurso a um custo barato. Por outro lado, pra quem compra imóvel é uma operação bastante atrativa, porque ele está comprando tijolo de uma maneira muito mais profissional que é FII e está tendo a Caixa Econômica como inquilino. Então ele está comprando um imóvel ao qual ele não teria acesso, de grande porte, está comprando um inquilino que ele não teria acesso, porque com mil reais ele pode virar cotista desse fundo ... Que imóvel você encontra pra investir por R \$20mil no mercado? Não tem. Esse é um imóvel que tem a Caixa como inquilino, dá renda mensal, obviamente é um investimento de risco, mas é um risco bastante mensurável. E isso trouxe pra nós do mercado, na minha opinião, uma grande vantagem que é a popularização do investimento, nós temos um grande trabalho pra fazer que é divulgação da cultura do FII. A Caixa Econômica fazendo um trabalho de venda e se ela conseguiu vender pra cinco mil pessoas, na minha opinião, ela ofereceu pra 30 mil. Se ela ofereceu pra 30 mil são 30 mil que souberam que existe fundo imobiliário, eles viram que a Caixa está envolvida nisso, isto dá credibilidade ao instrumento. O Almirante Barroso inicia uma nova era no mercado...”

Este momento de nossa investigação nos revela dois elementos importantes para que exista liquidez: a popularização do investimento e a pulverização de investidores. $O$ que pode nos indicar que a liquidez, que é condição para a maior mobilidade do capital como afirmamos anteriormente, não é alcançada sem estratégias empreendidas por parte do mercado para superar certos limites. Ainda podemos acrescentar aqui a palavra democratizar, utilizada por Kleinmam e “cultura” por Belleza. Democratizar significa dar chances de mais pessoas, inclusive o pequeno investidor, o poupador, de participar junto ao grande investidor desses projetos imobiliários de alto padrão em lugares valorizados da cidade. Entretanto, fica explicito que a igualdade de investimento não existe, porque o ganho é sempre proporcional ao investimento realizado na compra das cotas, ou seja, quem comprar mais cotas receberá uma rentabilidade maior. A palavra “cultura” é empregada no jargão desse mercado no sentido de que é necessário compreender que a escritura é ônus, como veremos mais adiante; o investidor do mercado imobiliário tem que incorporar uma cultura de investir num projeto 
mobiliário de base imobiliária, em que não há escritura e sim cotas que são títulos mobiliários. Portanto, para eles é preciso difundir informação e cultura. A partir daí faz sentido pensar em democratização, pulverização, popularização. Essa discussão, que será retomada mais adiante, pode nos abrir caminho para apresentar a terceira fase dos FIIs que tem início em 1999 e que surge a partir do problema da diminuição do limite posto pela Secretaria de Previdência Completar aos fundos de pensão no que se refere aos seus investimentos no segmento imobiliário. Sobre características dessa fase Machado diz:

“Aí veio a terceira onda, em que lançamos aquele produto lá [Shopping Pátio Higienópolis], que é até hoje o mais conhecido, que foi o início da terceira onda que se caracterizou pelas ofertas públicas de cotas para investidores individuais, investidores no varejo. A gente foi atrás de gente que compra $\mathrm{CDB}$, cota de renda fixa e, principalmente, o sujeito que compra imóvel, flat pra alugar. Até a gente fez uma grande mudança de paradigma, porque ninguém conseguia acreditar, pois falavam que culturalmente o brasileiro só gostava de investir em imóvel e não em papel e nós conseguimos fazer essa mudança. E outra característica dessa terceira onda são os fundos que chamamos de single access, fundo de um imóvel só, porque tinha uma razão de ser, é o conceito de tangebilização. O sujeito precisa saber que está comprando uma cota do Pátio Higienópolis e não de um conjunto de shoppings em diferentes lugares; precisava ser de alguma coisa que ele conseguisse tangebilizar".

Há, então na terceira, fase uma mudança de investidor. Até este momento os maiores investidores eram os fundos de pensão. A partir de 1999, o mercado se voltou para as pessoas físicas, o que o levou a encontrar estratégias para atrair mais investidores. Os primeiros fundos de investimento imobiliário voltados para pessoas físicas foram o Shopping Pátio Higienópolis e o edifício de escritórios Financial Center (um dos fundos que estamos acompanhando de perto na cidade de São Paulo). Uma das estratégias encontradas foi oferecer os FIIs a investidores de flat. Outro ponto relevante no raciocínio de Machado é quando apresenta o que chama de conceito de tangebilização, que é oferecer o título, a cota, de um único imóvel ao investidor pessoa física, porque para o investidor de imóveis ele precisa saber e ver onde está investindo seu capital; podemos aqui retomar a questão da cultura e difusão de informação, 
observando que vão sendo criadas estratégias que indicam as superações necessárias para que este instrumento se desenvolva. De acordo com Belleza, o flat era um produto do mercado imobiliário que estava sendo vendido “que nem água”, por isso o mercado de FIIs foi a procura deste público. O FII Financial Center, acima citado e tido como exemplo dessa nova fase, exigia que o investidor entrasse com um valor mínimo de R\$70 mil para aquisição de cotas, montante de dinheiro muito próximo ao necessário na compra de flats, às vezes inferior. Os argumentos utilizados para convencer o investidor deixar de investir num flat para investir em um FII são construídos a partir da comparação das vantagens de um tipo de investimento (os FIIs) e desvantagens de outro (os flats).

\section{Segundo Belleza:}

“O flat, na minha opinião, fez sucesso em SP por cinco motivos principais. O primeiro deles é que ele consegue atingir cinco anseios do investidor: o flat tem tijolo, é lastro, ele está comprando uma coisa que ele sabe que se amanhã der alguma coisa errada ele vai morar lá, ele põe o filho pra morar, ele pensa nisso como um bem de raiz. Segundo ponto, o flat, a proposta é pagar renda mensal, todo mundo gosta de ter renda mensal, nossos compromissos são mensais. O terceiro ponto é a administração terceirizada, ter um investimento imobiliário e não ter que se preocupar com o inquilino, não ter que se preocupar se o cano furou, é uma delícia, é o que todo mundo quer. Quarto ponto, sistema de socialização do risco, ou seja, eu não tenho a renda do meu flat, eu tenho o sistema do pool, isso é um sistema de pulverização do risco. O quinto ponto, o valor acessível, criou uma mercadoria que custava $\mathrm{R} \$ 70$ mil, $\mathrm{R} \$ 100$ mil que a pessoa podia ir pagando aos poucos...”

Entretanto, houve na cidade de São Paulo uma grande oferta deste produto (flat) trazendo uma grande taxa de vacância. Como afirma Belleza, "há muito mais gente querendo pôr dinheiro nisso do que tem gente querendo dormir nestes flats”. Então a partir da constatação desta super oferta de flats, desta “irresponsabilidade do mercado”, segundo o entrevistado, e conseqüentemente uma baixa na rentabilidade para os investidores do mercado de flats, o FII entra em cena como uma possibilidade para o investidor. Este contexto leva Belleza afirmar: 
“Como atender essa massa de pessoas que tem esse recurso e que produz dinheiro e que está produzindo dinheiro agora e está querendo investir em imóvel? É o FII. Será que ele atende os cinco anseios? [que os flats oferecem] Vamos lá! Primeiro anseio: é o mais difícil de dizer que a gente atende que é o lastro imobiliário, o sujeito está acostumado a receber uma escritura e aquilo pra ele é tudo, a gente foi criado, treinado para achar que a escritura é a melhor coisa do mundo, mas eu digo que escritura é ônus. Se você tem um imóvel de $\mathrm{R} \$ 50$ mil que você quer vender e você tem a escritura, você primeiro tem que ter uma certidão que o imóvel existe, que o imóvel é seu, depois você precisa provar que você não está devendo R \$2 mil pro Credcard, se você for casado você vai precisar da assinatura de sua esposa, mesmo se for separado por separação total de bens, o comprador cauteloso vai querer a assinatura da ex-mulher, você vai pagar por essas certidões, você vai esperar, tem que ir à cartório, o comprador vai ter que gastar com ITBI. É todo um grande drama pra poder fazer um negócio de $\mathrm{R}$ \$50 mil. Se você tiver $\mathrm{R} \$ 10$ milhões em Petrobrás você passa a mão no telefone e manda vender, vai pagar uma corretagem de $0.5 \%$, se pagar, e não precisa pagar por certidão, pode estar brigando com a mulher, devendo no Credcard, e daí? É a mobilidade do mercado financeiro. Então na minha opinião, lastro imobiliário o FII tem, ele tem imóvel dentro dele, de quem é a escritura? A escritura é do fundo e o fundo é um jeito de repartir essa escritura em vários pedaços, é dar mobilidade de fracionar ao que não é fracionável, ao que não é móvel. Então no primeiro ponto é o maior desafio, é um desafio cultural, mas eu acho que a gente ganha de dez a zero. Segundo ponto: renda mensal. Terceiro ponto: administração terceirizada. Nesse ponto, nós temos uma vantagem maior, porque somos obrigados a ter uma instituição financeira que administra o fundo. A administração financeira tem que responder pelos atos que pratica, ela é fiduciária na operação. Obviamente isso encarece um pouco a operação porque você está pagando pra alguém tomar conta, mas vale muito a pena, porque a remuneração financeira pra administração de FII é ridícula de barata. O quarto ponto: a socialização de risco; no FII já é por natureza, não existe dono da cota com vista pro mar e dono de cota com vista para o estacionamento. É um condomínio de investidores. O último ponto, que é o valor acessível, a gente ganha de mil a zero. Você tem fundos que vendem cotas de mil reais, que é o caso desses FII do Banco do Brasil e da Caixa, então você populariza a propriedade imobiliária e cria uma divisibilidade do 
patrimônio onde você pode reinvestir a renda mensal. O sistema do flat só serve pra investir no setor de hospedagem e o FII você poder ir para qualquer setor da economia, inclusive hospedagem, temos fundo de galpões, hospital, agência bancária, shopping center, prédio de escritório, então tem uma variedade muito grande”.

Nesta fala de Belleza já podemos observar a questão da flexibilização da propriedade privada, assunto que retomaremos mais adiante.

Outra estratégia tomada por esses profissionais para ganhar o pequeno investidor foi, segundo Machado, a seguinte:

“Na ocasião, o que nós estávamos buscando eram aqueles investidores dos flats aqueles que estavam dispostos a pagar cem cento e poucos mil reais por uma unidade de flat e tem um rendimento mensal oriundo da exploração do flat pela operadora hoteleira. Então pra isso quem acessava esse cara era o corretor imobiliário e não um corretor de valores e então nós conversamos com a CVM, fomos lá e montamos um processo com a CVM dizendo o seguinte: autoriza esse pessoal a entrar neste mercado apresentando o produto imobiliário e não como um fundo de investimento, o fundo de investimento quem vai apresentar é o banco, mas ele é que tem o acesso ao investidor imobiliário, então deixa ele participar, ele apresenta o produto imobiliário e a gente vende a alternativa, a oportunidade de investimento pra ele”.

Observamos que foi necessário, para que os FIIs fossem vendidos entre os pequenos investidores, a presença de empresas imobiliárias conhecidas no mercado, tais como Lopes, para realizar a apresentação do empreendimento imobiliário. Imobiliárias não podem vender cotas de FII, mas há a possibilidade de formatar a venda com a ajuda de grandes empresas imobiliárias para se parecer com a venda de um flat, para chamar a atenção de investidores de produto imobiliário.

A quarta fase do mercado é marcada, de acordo com Machado, pela entrada de bancos com grandes redes de agências (como Caixa Econômica Federal e Banco do Brasil) que começaram a fazer uma distribuição maior dos FIIs. De acordo com Machado, esses bancos “fazem de fato uma distribuição massificada desse produto”. Outra característica da quarta fase é a isenção de $20 \%$ do imposto de renda para pessoas 
físicas sobre os rendimentos relativos aos fundos de investimento imobiliário que possuírem mais de 50 cotistas, estiver operando em bolsa e o cotista não pode ter mais do que $10 \%$ das cotas. Essas duas características apontam novamente a questão da liquidez, pois os grandes bancos de varejo criam chances reais dos FIIs serem mais conhecidos. A isenção, acima mencionada, também aparece como um atrativo a mais para que o pequeno investidor aplique seus investimentos em cotas de FIIs.

Retomamos aqui um dos pontos centrais em nossa pesquisa, o par contraditório mobilidade e imobilidade. A articulação entre a base imobiliária dada pelo imóvel (o setor imobiliário) e a mobilidade do mercado de capitais revela duas frações de capital que se realizam de formas diferenciadas no tempo e no espaço. A primeira fração é capital imobilizado no solo urbano e a segunda possui uma liberdade possível de se mover (por se tratar do mercado mobiliário). É justamente essa aproximação, criando essa interface, que vai procurar oferecer à fração de capital imóvel uma mobilidade possível. A diferenciação espaço-temporal de realização desses capitais surge como elemento de análise, porque observamos que o mercado de capitais possibilita que o tempo de rotação dos capitais aí aplicados seja menor; por outro lado a dimensão espacial está posta para a primeira fração pelo motivo de estarmos nos referindo ao capital imobilizado no solo urbano, num determinado lugar da cidade, que não se sabe ao certo o tempo de retorno do capital investido, e a ligação deste processo ao processo de valorização imobiliária e valorização do espaço. Ambas frações revelam também um movimento entre a imaterialidade do processo e sua materialização. E ainda se deve refletir sobre esta articulação, no sentido em que ela nos coloca diante de uma relação entre diferentes sujeitos sociais - na economia e na política - tanto é que nos deparamos com o Estado, com bancos, com investidores, com instituições financeiras (como a Bovespa), com sindicatos (como o Secovi), com empresas e empresários do ramo imobiliário e da construção civil. (É interessante observar que a todo tempo os sujeitos empreendedores do instrumento FII procuram mudar o perfil do investidor de imóveis, como temos observado nos trechos de entrevistas aqui expostos, no sentido dele se tornar também um investidor do mercado de capitais).

Podemos ainda entender que a estruturação de um fundo de investimento imobiliário tem como objetivo dar mobilidade a uma certa quantidade de capital investido na construção. Quando o fundo é criado antes do imóvel estar construído, ou seja, como forma real de financiamento da construção do imóvel, este capital absorvido poderá circular e ser reinvestido de acordo com a necessidade de quem está 
administrando o empreendimento (a incorporadora e a construtora). Nesse caso, parte do capital pode ser empregada para o pagamento de "aluguel adiantado", isto é, uma promessa acordada anteriormente de pagamento de rendimentos mensais aos investidores que compraram cotas do fundo, antes do imóvel ser entregue ${ }^{56}$. Ou seja, os recursos captados através do fundo poderão circular em outras esferas, inclusive financeiras. Quando o fundo é criado para vender um imóvel ou parte dele (um imóvel já pronto e em funcionamento), o capital investido na realização do empreendimento imobiliário objeto do fundo, pode ser então reposto aos empreendedores ${ }^{57}$, o que nos permite dizer que, nesta operação, o fundo se presta a reduzir o tempo de rotação do capital investido fazendo com que ele se realize num tempo menor. Assim, o capital aplicado no empreendimento tem a possibilidade de voltar às mãos do empreendedor mais rapidamente. Este capital já realizado adquire mobilidade potencial.

A mobilidade que o mercado de capitais pode trazer ao mercado imobiliário, no movimento de associar um título a um ativo imobiliário, está intimamente ligada à liquidez que existe no mercado mobiliário. A partir das características da quarta fase dos FIIs (a entrada dos bancos de varejo, isenção dos $20 \%$ às pessoas físicas que investe em fundos com mais de 50 cotistas e que são comercializados na bolsa de valores), entendemos que a procura por liquidez tem um papel central neste momento.

A respeito do tema liquidez, Kleinmam afirma que "FII é uma aplicação que não tem liquidez igualzinho a um fundo de renda fixa. Então você não pode aplicar o dinheiro numa coisa que depois você fique preso”. Foi a partir desta afirmação que começamos a relativizar a ocorrência de liquidez e observar que a possibilidade de liquidez se liga a outros elementos. Kleinmam ao ser questionado sobre a existência de liquidez em operações com FII nos dá uma pista importante:

"Isso daí [liquidez]como você consegue e quando você consegue? É bem óbvio. Você só vai conseguir uma liquidez condizente quando você tiver um mercado bem amplo. Nos EUA, por exemplo, tem fundos especializados, tem um fundo famoso que se dedica a shopping centers, tem outro fundo famoso que se dedica a prédios de escritórios, pura e exclusivamente. E são fundos de 4, 5, 8 bilhões de dólares. Esse fundo de US\$8 bilhões que negocia só escritórios, ele compra e vende diariamente, gira diariamente

\footnotetext{
${ }^{56} \mathrm{O}$ assunto sobre "aluguel adiantado" será retomado com mais detalhe quando da discussão sobre o FII Contental Square Faria Lima.

${ }^{57}$ Entendemos, neste momento do texto, por empreendedores as empresas construtoras e incorporadoras.
} 
entre os cotistas um prédio de 40, 50 milhões de dólares, por dia. É como se você pegasse uma Torre Norte [uma das torres de escritório do Centro Empresarial Nações Unidas em São Paulo] e todo dia mudasse de dono, está certo? E quando que isso pode acontecer? Quando você tem milhares... Por que acontecem giros financeiros de 1.800 milhões de dois bilhões de reais por dia? Porque tem milhares de cotistas todo dia comprando milhares, comprando dinheiro. Então na medida em que os fundos de investimento imobiliário virarem uma opção real de investimento para os investidores como um todo e você começar a ter investidores que dizem "Ah, eu vou comprar a cota do Continental Square, vou vender do Pátio Higienópolis, porque com o Pátio Higienópolis eu já ganhei e agora eu vou...” e começar a ter esses movimentos, essas transações, aí você vai ter evidentemente um giro e uma negociação grande e aí vem a liquidez. Por enquanto a liquidez não é essa. Por enquanto a liquidez é similar ao do mercado imobiliário. Por exemplo, se você é cotista hoje de qualquer FII e você se estiver perdendo, ninguém quer comprar aquilo que você tem. Agora, tem muitas, inclusive o Continental Square e Pátio Higienópolis e Hospital da Criança, entra na Bovespa e você vai ver que todos os dias tem transações 20, 50, 60 mil, 90 mil, 100 mil. Tem fundos que não tem transação, por exemplo, porque ninguém quer vender. Se você é dono de Pátio Higienópolis, que rende muito bem, ninguém quer vender. Você é dono do SPC Piedade [Shopping Center em Salvador], que eu administro, há dez anos que ninguém vende uma cota”.

Esta fala nos revela que a liquidez não acontece sem mediações, isto é, ela não se dá automaticamente pelo fato do FII articular o mercado mobiliário e o imobiliário. Assim, as falas que analisaremos a seguir podem nos revelar elementos centrais para que haja liquidez, o termo mais utilizado é pulverização. A esse respeito Ventura afirma:

"Acho que existem ganhos na pulverização que se consegue com o fundo. Você tem vários ativos imóveis que você pode transformar em fundo e vender em cotas. Segurança... também não vejo muita perda em relação à segurança, em relação a imóvel propriamente dito e a questão liquidez, eu não sei. Liquidez é uma questão de oferta e procura de ter comprador, tem que ter gente querendo vender e ter gente querendo comprar, isso que é a liquidez. Acho que tem vários tipos de imóveis que tem maior ou 
menor liquidez, tem também fundos que tem maior e menor liquidez. Acho que é difícil generalizar, falar: os fundos têm mais liquidez, não me salta aos olhos uma liquidez maior que a classe de imóveis, mas tem mais que determinados tipos de imóveis, tem menos de determinados tipos de imóveis”.

Essa afirmação é importante por relativizar a questão da liquidez e que para alcançá-la é necessário um ambiente - um mercado - no qual as negociações sejam intensas. Além disso, é preciso bolar estratégias para que cada vez mais o número de interessados aumente.

Sobre este assunto Belleza discorre:

“A pulverização é fundamental e crucial nesse mercado, nós temos que conseguir pulverizar mais. A gente só vai conseguir na medida em que a gente tem a estrutura de distribuição desse produto bastante eficiente e essa estrutura passa inegavelmente pela entrada de bancos de varejos nisso. Tem que entrar, ninguém pode obrigá-los, mas com a vinda da Caixa Econômica e do Banco do Brasil já foi um grande passo, se a operação da Caixa, o Almirante Barroso, trouxe 5.300 investidores, o do Banco do Brasil declarou cerca de 6mil e tantos, é o Banco do Brasil Progressivo, é um fundo que o Banco do Brasil colocou o seu imóvel no Andaraí, que é um centro administrativo que ele tem no Rio de Janeiro, e o edifício sede um de Brasília. O Banco do Brasil fez um negócio ainda mais revolucionário, porque ele colocou o nome do fundo como Fundo Imobiliário Banco do Brasil Progressivo, então aí tem duas coisas importantes, ele colocou o nome do banco no fundo, a Caixa só colocou Almirante Barroso, que é o nome do prédio e o fundo da Caixa está claro que vai ser dono daquele prédio e nada mais. Só que o Banco do Brasil fez o fundo dele chamado Banco do Brasil Progressivo. O que eu subentendo disso? Primeiro que tem o nome do banco no fundo que dá maior credibilidade ainda, segundo se ele é progressivo acredito que ele vá colocar mais imóveis ainda, já começou com dois e não deve parar por aí, que é o certo”.

Alguns elementos que Belleza traz em sua fala são importantes. A referência à palavra pulverização é recorrente e aqui ela aparece como fundamental e crucial, nas palavras de nosso interlocutor, para o bom andamento dos negócios envolvendo fundo 
imobiliário. Outra contenda é a presença de dois grandes bancos de varejo estruturando e comercializando cotas de FII, que é uma característica recente (referente à quarta fase). É interessante notar o nome do fundo do Banco Brasil citado na entrevista: $B B$ Fundo de Investimento Imobiliário Progressivo, que como podemos ler se trata de um FII com dois imóveis do próprio banco (um no Rio de Janeiro e outro em Brasília), mostrando que começa a existir no país fundos com mais de um imóvel e que, como o próprio nome do fundo indica, poderá ter sua carteira ampliada com a entrada de mais imóveis. No caso deste fundo do Banco Brasil, são imóveis do patrimônio do banco, isto quer dizer que esta instituição está vendendo parte de seu patrimônio imóvel e preferindo pagar aluguel, ao invés de permanecer com este capital imobilizado. É um fundo que vende imóveis para investidores e se torna uma saída para o banco conseguir capital de forma mais rápida e a baixo custo. Uma questão a ser colocada (não somente a esse fundo específico, mas também a outros que se formam da mesma maneira) é se antes da venda do patrimônio ao suposto fundo o capital investido pelo banco nos edifícios (ambiente construído) já se realizou.

Continuando o debate sobre a liquidez, Machado, para ilustrar esta questão, utiliza como exemplo o sujeito que antes comprava um imóvel tipo flat, desconsiderando que houve excesso de oferta de flats em São Paulo e que a renda teve uma queda considerável; a rentabilidade deste investimento também será considerada de $1 \%$ neste caso. Afirma ele:

"O dono desse imóvel, do flat que custa 120mil reais e se ele quiser 20mil reais pra comprar um carro pra um filho ele tem que vender o imóvel inteiro em cartório, pegar certidão disso, certidão daquilo, se ele for casado a mulher tem que assinar, uma burocracia infernal, o cara vai ter que provar que ele não é bandido, aí ele vende, ele gasta com registro, ITBI, vende aquilo e no final do dia, 120 vira 110, usa 20 e sobra 90 na mão dele e ele não consegue repor o ativo, ele não consegue recomprar o flat, ele vai ter que esperar um tempão até que os 90 virem 120mil pra ele ir lá e comprar. Se ele tiver os mesmos 120mil reais aplicado em qualquer fundo, se ele quiser vender 20, que é o tamanho da necessidade dele, ele vende os 20 . Pode ser que não tenha a mesma liquidez de uma renda fixa que ele possa resgatar, a cota não é resgatável, ela só tem liquidez no mercado secundário assim como um imóvel, o imóvel você não resgata, você tem que encontrar um investidor interessado. Ele pode vender mais barato, porque talvez esteja 
com pressa, mas os 90 não saíram do ativo dele. E se ele quiser repor os 30 ele vai comprando cota devagarzinho. Essa conveniência e transparência do mercado de capital é que o mercado imobiliário não tem e que o fundo imobiliário traz essa condição do mercado imobiliário, porque a renda do fundo imobiliário é um projeto imobiliário, é um imóvel, por isso se faz o link da segurança do imóvel com a conveniência do mercado de capitais”.

Observamos nesta fala que o fundo é um mecanismo financeiro que oferece uma certa mobilidade, que tem como condição a liquidez, que por sua vez para, se realizar, depende de um mercado pulverizado e com vitalidade e um ativo que seja atrativo do ponto de vista da rentabilidade, do tipo de construção e do lugar que ocupa na cidade.

Outro apontamento a ser feito é a necessidade de que a comercialização de cotas de fundos imobiliário seja feita em mercado secundário, como a Bovespa, por exemplo. Sobre isso, diz Belleza:

\footnotetext{
"Durante muitos anos no meu site, eu defendi a idéia de negociação de cotas de FII para o mercado secundário, tinha que ser exclusivamente em bolsa e eu tive muito dificuldade de ver essa minha tese vencedora, porque havia muita resistência do mercado, você vendeu cota pro investidor pessoa física, no outro dia o papel tem que estar na bolsa ... Primeiro lugar é regra justa de formação de preço, é transparência, é difusão de informação. É fundamental para o investidor ter esse ambiente de negociação pra não ser enganado, pra não fazer negócio sendo prejudicado. Tem que haver um lugar sério, regulado, fiscalizado e com facilidade de disseminação da informação para poder criar liquidez. Porque todo mundo queixa que imóvel não tem liquidez, em bolsa se consegue se o produto for bom ... A operação tem que ser boa, se a operação for rentável, você tiver uma expressão de cotistas grandes e usar FII, você não tenha dúvida que esse papel vai ter liquidez em bolsa, isto está se provando todos os dias na Bovespa”.
}

A estratégia de lutar para que as operações referentes aos FIIs sejam realizadas na Bovespa, por exemplo, envolve e revela um conflito entre o mercado (na figura dos empreendedores do setor e investidores), a aceitação e aprovação da CVM (figura que representa o Estado como regulador e fiscalizador deste processo) e a própria Bovespa. 
A idéia de luta traz à tona a dimensão entre o político e o econômico, a realização dessas duas instâncias em uma articulação contraditória.

Este fragmento traz para o debate o último ponto com relação à importância da liquidez para a realização da mobilidade que este instrumento pode oferecer. Pulverização, democratização e popularização do investimento são ações que devem ser empreendidas como estratégias para que a liquidez almejada se efetue. Representam também um grande esforço empreendido para a constituição de um arcabouço ideológico que corrobora para criar um movimento favorável à reprodução dos investimentos através de fundos imobiliários. As diferentes fases de desenvolvimento e “amadurecimento" dos fundos revelam diferentes tipos de investidores que aplicaram capital neste instrumento. A primeira fase pode mostrar como os fundos foram utilizados por grandes capitalistas e por grandes instituições financeiras como um veículo fiscalmente eficiente e uma forma de gerenciar patrimônio. A segunda trouxe à cena os fundos de pensão fechados: Previ, Funcef, Petros e Valia como os maiores investidores em fundos imobiliários no período. A terceira revela que houve um desafio para encontrar um novo investidor deste novo produto; com o mecanismo mais estruturado, foi possível procurar os médios e pequenos investidores imobiliários. No entanto, a terceira e a quarta fases revelam a necessidade de criar o investidor. Esta criação de um novo investidor é dependente de que uma cultura de se investir no mercado mobiliário seja difundida e incorporada por estas frações potenciais de investidores (estão neste conjunto os pequenos investidores de imóveis bem como sujeitos que nunca teriam a possibilidade de ter sua pequena poupança alocada em tal forma de investimento). A produção e difusão desta cultura é sine qua non para a reprodução do processo. Essa cultura em processo de difusão se choca com uma mentalidade patrimonialista / rentista gestada no processo de formação históricoterritorial do Brasil, em que a terra desempenha um papel importante.

Este desencontro que se manifesta aqui explicita a questão da propriedade da terra. Como foi apontado anteriormente, a mentalidade de possuir e comprovar a propriedade privada do solo urbano por meio de escritura é um desafio a ser superado para o desenvolvimento do mercado de fundos de investimento imobiliário, pois, como o ativo imobiliário é fracionado em cotas, os investidores estão comprando títulos mobiliários referentes a uma fração ideal do imóvel, os quais permitem que participem de um condomínio fechado de investidores. Portanto trata-se de um fundo (que representa a totalidade das frações) que possui a escritura de tal imóvel. 
Segundo Machado, a propriedade da terra pertence ao fundo e é intocável. O fundo é o proprietário do imóvel, mas quem detém a propriedade em nome do fundo, é o banco administrador do mesmo. Esse mecanismo é conhecido por propriedade fiduciária, isto é, quando detém a propriedade em confiança de um terceiro (a instituição administradora do fundo detém a propriedade em confiança dos cotistas). Por exemplo o caso do FII Torre Norte: através da geração da matrícula do imóvel, observa-se que o proprietário é Banco Ourinvest em caráter fiduciário do Fundo Imobiliário Torre Norte. De acordo com a legislação é necessário que o imóvel seja registrado desta maneira e que assim são estabelecidos os limites de propriedade para que este patrimônio não se comunique com o do administrador; não podendo ser penhorado, dado como garantia, nem ser executado por nenhum credor. Kleinmam explica a questão do fracionamento da propriedade em cotas:

"eu tenho a escritura desse andar. Agora o que eu fiz? Eu transformei este andar em 5.000 títulos - cotas - e crio um FII passando por todo o crivo da CVM para aprovar e etc. A partir desse momento, esse andar tem sua escritura, mas também são 5 mil cotas ... Quem compra cota compra um pedaço do prédio, ele parcelou, só que de uma forma diferente. Em lugar de comprar via uma fração ideal está comprando por uma cota, mas ele é tão dono quanto e tem só vantagens e uma das desvantagens. Por exemplo, se você é dono de 5 mil cotas desse andar aqui em lugar de ser dono de meio andar, vamos supor, e você precisa amanhã o equivalente a mil cotas para um problema que você teve. Se você é dono de 5 mil via escritura e você tem que juntar mil, de algum jeito você tem que ainda queimar meio andar, vai conseguir 3, 4, tira mil e paga essa dívida. Se você é dono via títulos, você vende só aquela parte de título daquela dívida que você tem. Até pode pagar com os títulos a dívida. Você não pode pegar digamos os banheiros de um andar que vão valer $\mathrm{R} \$ 100$ mil e você dizer para o cara 'te vendo os banheiros'. O que eu faço com os banheiros? Mas, você pode pegar 100 mil cotas e dizer 'essa cota vale 1 [R $\$ 1,00]$ aqui eu tenho $R \$ 100$ mil via cotas' e você é dono de R\$100 mil e não dos banheiros, você é dono de um pedaço do fundo, entendeu?"

Observamos que existe um movimento neste processo de passagem da propriedade para cotas - momento em que transforma a propriedade em abstração. 
Tem-se a propriedade do imóvel que é fracionada em cotas passíveis de serem compradas e vendidas que propiciam rendimentos proporcionais via aluguel e que representam a propriedade (processo de flexibilização da propriedade) retomada como tal nas mãos do administrador do fundo em caráter fiduciário. Desta forma o cotista possui títulos mobiliários que, ao se agregar com outros títulos, recompõe abstratamente a propriedade privada da terra. O fundo é constituído através de uma junção dos recursos captados via investidores, ele é um condomínio que não tem personalidade jurídica, então precisa pegar “emprestado” a personalidade jurídica do administrador. Por isso a existência da propriedade fiduciária.

Do ponto de vista dos sujeitos que trabalham com fundos de investimento imobiliário, esta estratégia cria uma forma de dar a um número maior de investidores a propriedade da terra em lugares valorizados da cidade, permitindo que os diferentes capitais envolvidos se realizem. Aqui a propriedade se destaca como um ramo cumulativo; o sentido é a acumulação de capital. Os investidores ganham rendimentos sobre aquele pedaço (cota) abstrato que possui (interesses abstratos da acumulação). Assim, à propriedade privada da terra ligam-se as possibilidades de captação de riqueza (mais valor) através do aluguel dos imóveis objetos dos fundos.

O cálculo do patrimônio do fundo, bem como o número de cotas, e a forma como se dá a rentabilidade dos fundos são fundamentais para a compreensão do funcionamento deste instrumento. Primeiramente, se faz a avaliação do imóvel, que compõe o patrimônio do fundo. Essa avaliação é feita por uma empresa especializada e independente dos agentes envolvidos. De acordo com Machado,

\begin{abstract}
“O imóvel vale o que ele é capaz de gerar de renda ao longo do tempo. Se custou 100 milhões pra Hines construir aquele prédio ou se custou 200 pra mim, investidor, pouco importa, eu quero saber é quanto eu vou ter de rendimento a uma taxa tal e esse prédio é bom e novo o suficiente pra me dar isso por 10 anos? O que ele é capaz de gerar ao longo do tempo e por quanto tempo”.
\end{abstract}

Após esta avaliação, apresenta-se a proposta de FII para registro na CVM (já estruturado com valor de patrimônio, a quantidade de cotas, valor de cada cota), o que concretiza a emissão. A matemática do lado contábil não é tão complexa. Um exemplo pode ser o FII Almirante Barroso, que possui um patrimônio de R $\$ 104,8$ milhões. A 
Caixa Econômica Federal emitiu 104.800 cotas de R\$1mil cada. Portanto, cada cota vale R\$1mil. No momento do lançamento, não há dúvida de que cada cota foi lançada a R\$1mil, ou seja, a CEF está precificando a cota arbitrariamente. Com os mesmos $\mathrm{R} \$ 104,8$ milhões a CEF poderia ter emitido cada cota a $\mathrm{R} \$ 100$. O valor de cada cota e, por conseguinte, a quantidade de cotas de cada fundo é decidida no momento de criação do fundo, por quem está estruturando-o. O valor patrimonial das cotas é o valor do imóvel dividido pela quantidade de cotas e esse valor do imóvel é depreciado mensalmente e acrescido do fundo de receitas financeiras (fundo de reserva). Beleza explica em sua fala o que ele chama de lado contábil e o lado de mercado (o primeiro a partir de um exemplo hipotético; o segundo a partir de um fundo existente no mercado).

"Nós emitimos num fundo de 100 milhões de reais com cada cota a mil reais, 100 mil cotas de mil reais. Passou-se o tempo, eu só estou falando de contábil, houve uma depreciação durante dois anos, vamos dizer que no primeiro ano foi depreciado em 4\%, o patrimônio contábil virou 96 milhões, mais um ano mais 4\% de 96 milhões, então isso aqui caiu pra 92 milhões e 160 mil isso é o patrimônio contábil. Então nós temos 100 mil cotas, isso não muda, então cada cota está valendo agora 921,60 reais, então houve uma perda contábil. Então contabilmente houve essa diferença. Vamos imaginar que eu queira fazer uma avaliação desse imóvel agora. Contrato um avaliador profissional e chegamos ao valor de 102 milhões. O que eu faço? Eu posso levar isso à contabilização e aí a minha cota passa a ser patrimonialmente o valor dela $\mathrm{R} \$ 1.020,00$ cada cota. O que mudou isso no mundo pra mim, nada. Isso é só uma informação contábil. Não mudou nada, você ficou mais rico ou menos rico? Agora vou te contar. Emiti 100 mil cotas, vendi ao mercado cada cota a mil reais, faturou R \$100 milhões. Esse prédio está alugado, começa a render, estou falando agora exatamente do FII Almirante Barroso, só que o número é de R\$104 milhões e 800 mil. Quanto ele pagava de aluguel no começo? 1,25\% sobre o valor do fundo, ou seja, ele estava dando de rendimento bruto $1,25 \%$, só que com imposto de renda na época. Por que todos os fundos têm esse número mágico de 1,25\%? Qual é o imaginário popular, o que o investidor quer? O sonho dourado dele, $1 \%$. Você pega 1,25\%, 20\% que tinha de imposto de renda na época, 20\% de 1,25 é 25 tira de 1,25\% dá 1\% líquido. Então o que aconteceu quando a gente começou com o FII Almirante Barroso, cada cota de mil reais, ela rendia 1,25\%. 1,25\% tirado o imposto de renda você tinha 
todo mês $\mathrm{R} \$ 10,00$ de renda. Está ótimo para o mercado. Aí, o que aconteceu? Chegou novembro acabou o imposto, então quanto ele começou a render $\mathrm{R} \$ 12,50$ líquido. O bruto virou líquido aí o que aconteceu? $\mathrm{Eu}$ investia, comprava na bolsa a mil reais a cota e recebia 1,25\% líquido. Só que como eles tinham alugado o imóvel por 1,25\% e já tinha passado um ano e pouco já tinha tido um reajuste pelo IGPM, 1,33\%. Então já estava rendendo $\mathrm{R} \$ 13,30$. O que aconteceu no papel? Começou a subir na bolsa, quando acabou o imposto os preços imediatamente se reajustaram e hoje, quanto está a cota do FII Almirante Barroso? R\$1.380,00. Quanto ele dá de renda? 1\%. Então, o que precifica os FII é o preço de mercado, é por quanto você consegue vender. O que adianta dizer que esse andar aqui, na minha opinião, vale 10 milhões de reais? Se eu tenho um andar de 10 milhões de reais eu tenho que está alugando isso aqui pra alguém por $\mathrm{R} \$ 100$ mil por mês. Se eu não estou conseguindo alugar a $1 \%$ ao mês, esse andar não vale R \$10 milhões de reais. Eu não sou obrigado a vender, mas vou ter que vender mais barato. $\mathrm{O}$ que baliza o papel de renda mensal é a tentativa de remuneração que o investidor tem”.

O rendimento dos fundos é sempre distribuído mensalmente. Este rendimento provém da locação de edifícios comerciais, shopping centers, hospital, armazém - de um contrato de locação. A política de investimento é definida no regulamento do fundo, assim como toda a estrutura deste. Em todos os fundos há um fundo de reserva, reserva de contingência, que é patrimônio do fundo, portanto patrimônio dos cotistas. Este fundo de reserva fica aplicado em renda fixa.

A valorização patrimonial do edifício, por estar localizado num determinado lugar da metrópole, chega ao cotista por meio do aluguel, que pode ficar mais caro, o que vai influir na rentabilidade do fundo. Segundo Belleza, a valorização tem o mesmo impacto para o cotista tal qual se ele fosse sozinho dono de todo o edifício; "não muda em nada”. Continuando seu raciocínio, afirma que a valorização de um imóvel não significa a entrada de dinheiro na mão do proprietário, sendo que o mesmo ocorre com relação aos FIIs. Porém, procura-se receber um aluguel melhor.

Como o FII é uma aplicação financeira que possui um lastro imobiliário, acreditamos que seja importante fazer uma correlação entre este instrumento e as diversas possibilidades de aplicação financeira existentes no mercado. Esta correlação busca compreender, do ponto de vista do mercado, as vantagens, desvantagens, as 
diferenças de rentabilidade que podem nos auxiliar a entender o lugar do imobiliário nesta dinâmica. É interessante ressaltar que o fundo surge, do ponto de vista dos empreendedores financeiros/imobiliários, como uma forma passível de captação de recursos para o financiamento imobiliário. Já para os investidores aparece como possibilidade de diversificar investimentos, aplicando em um produto que ofereça renda mensal e de caráter conservador, pelo fato do lastro imobiliário. Diz Belleza: "Se você me perguntar: 'tem algum cliente seu que metade do dinheiro que ele pode poupar, ele põe no FII?’ Raríssimo. A maioria ainda tem um pequeno pedaço de sua poupança em FII.”

Sobre a diferença deste investidor investir em um fundo ou investir em outras modalidades financeiras, Machado afirma que:

"Você precisa diversificar seus investimentos e o FII é uma das opções para isso, uma opção inteligente de diversificar investimentos em imóveis de modo geral e, se você tem uma queda para investimento no mercado imobiliário, ele é um formato muito mais moderno e inteligente do que investir direto em imóveis. Então quando você começou a pergunta eu achei que você fosse falar da diferença de investir direto no imóvel e de investir em fundo imobiliário, mas você falando de investir em fundos de ações, CDB ou FII eu diria que a diferença é $100 \%$, não tem semelhança. Em termos de rentabilidade aí é uma outra história, mas aí a gente começa incorrer num erro conceitual e grave, na minha opinião, porque a gente está comparando diferentes classes de ativos: eu não consigo comparar uma ação com um imóvel, são riscos diferentes, são características diferentes, são maturidades diferentes ... Não dá pra comparar classes de ativos diferentes. Agora, o que dá pra comparar sim é FII na média rendem mais do que imóveis diretamente, pois se trata de empreendimentos diferentes, escala que o pequeno não consegue. E desde que começou o declínio da taxa de juros, alguns fundos estão rendendo mais do que aplicação financeira. A Selic agora a $14,75 \%$ ao ano muitos fundos vão estar acima, muitos. Então você tem uma atratividade maior; aquilo que você falou "o que falta para liquidez?, quanto mais pessoas investirem neste mercado maior será a liquidez. Então se eu tenho mais atratividade na renda eu vou ter mais gente investindo aqui, provavelmente vai aumentar a liquidez”. 
Embora Machado tenha dito que se tratam de ativos diferentes, e que, portanto, uma comparação com outros produtos financeiros se mostre inviável, é justamente esta diferença que procuramos identificar. De início, a partir dos trechos acima citados, fica claro que os FIIs são, antes de tudo, uma maneira de diversificar os investimentos. A fala de Belleza é reveladora quando diz que a maioria dos seus clientes não investe em FII sequer a metade do dinheiro que poderiam, mais uma vez reforçando a diversificação como prática de investimento no ambiente das aplicações financeiras.

De acordo com Ventura:

“Um atrativo do FII é o lastro imobiliário. Acho que há um quê de segurança dado pro investidor pelo fato de saber que ele está.... que por trás do investimento dele não tem só ações ou papéis de determinada emissora, mas tem uma participação num prédio que está lá, que ele enxerga, que ele vê e que algum valor há de ser preservado nesta situação. Acho que a diferença fundamental é essa, o resto, é rentabilidade, é liquidez, é risco de... depende da taxa de juros, cai ou não cai, o que isso afeta a rentabilidade, é um pouco isso como qualquer outro papel. Então a diferença fundamental está neste lastro mesmo”.

A fala de Ventura apresenta de maneira mais explícita o que pode ser a diferença entre os diversos instrumentos do mercado financeiro e os investimentos financeiros de base imobiliária, como os FIIs. O lastro imobiliário torna-se decisivo para atrair um determinado perfil de investidor, aquele que procura uma segurança e uma solidez que pode ser oferecida pelo investimento no setor imobiliário. Neste sentido, o termo lastro remete à idéia de equilíbrio, estabilidade, base, assento, fundamento ${ }^{58}$, que ainda desempenharia um importante papel na articulação daquela cultura rentista a uma possível mobilidade, ainda que uma mobilidade "conservadora”. Assim, o lastro imobiliário se colocaria em uma interface entre a cultura rentista (que se realiza classicamente através da propriedade) e a mobilidade dos movimentos do capital, permanecendo (de forma modificada) nas tendências contemporâneas de mobilização dadas pela financeirização. Aqui nos aproximamos da ponta material deste processo. No contexto dos FIIs, o lastro possuiria uma dupla face para a realização do processo: de um lado, pode se colocar como obstáculo, barreira, oposição à mobilidade procurada -

\footnotetext{
${ }^{58}$ Cf. Dicionário Eletrônico Houaiss, consultado em 29/11/2006 pelo site www.biblioteca.uol.com.br
} 
pela tendência à imobilização que sugere -, e, por outro lado, pode ser um elemento central como estratégia de garantir a mobilidade. Isto se realizaria trazendo até mesmo os investidores mais conservadores para o mercado financeiro, dinamizando-o.

É nesta direção que o setor imobiliário passa a ter o caráter de investimento financeiro. Sobre este assunto, Belleza discorre:

"Eu acho que existe ainda uma grande prevenção do setor bancário de varejo em relação a esse mercado [dos FIIs]. Isso é um problema no Brasil. Quando você percebe que qualquer papel de renda fixa, qualquer coisa que envolva juro, banco gosta, entende e faz muito rápido. Fundo imobiliário não, você percebe claramente que os grandes bancos de varejo brasileiros ainda não querem se envolver com FII. Tudo que é renda variável pra banco assusta. Os bancos comerciais são caretas, são tradicionalistas. Eu vou te dar um exemplo. Eu estou neste mercado de 1972... o diretor que cuidava da área imobiliária na época chamava-se diretor de crédito imobiliário, o nome já estava plugado no cargo do cara. Hoje o cara chama talvez diretor de negócios imobiliários, já mudou o foco. Banco só sabe mexer com imóvel na área de crédito ... Tudo que é financiamento o banco entende e eles só olhavam o mercado imobiliário pela ótica do financiamento. Qual a ótica do banco? Vou emprestar dinheiro para o Sávio comprar este apartamento aqui. Se você não me pagar por quanto eu queimo isso aqui para recuperar o meu dinheiro? Isto é uma ótica de financiamento. Agora muda a história, vamos falar de FII. Isto aqui é um shopping, isso daqui é um prédio de escritório. Quanto isso aqui dá de dinheiro, será que eu recomendo pro Sávio entrar nisso? Não tem nada a ver com o que eu estava falando antes, é outra conversa. É análise de financiamento e de investimento, não é crédito, são dois mundos completamente diferentes. Os bancos não sabem olhar isso aqui, os bancos não gostam de olhar isso aqui [FIIs]. Banco não gosta de se arriscar, o risco que ele gosta de correr é o risco de crédito. E isso que nós estamos tratando, FII, não tem nada a ver com crédito”.

Já Ventura diz, a respeito da diferença entre um financiamento imobiliário e um investimento imobiliário, que o primeiro se trata de dívida, enquanto que o segundo é equity. Um incorporador que necessite de dinheiro para terminar de construir um prédio pode optar como funding pelo FII ou pegar o financiamento. Se a opção for por um fundo imobiliário, vende-se o prédio para o fundo, que passa a ser dono do imóvel, 
sendo que tudo o que acontecer em relação ao fluxo de caixa deste prédio se torna responsabilidade do fundo. Caso o fundo estiver indo bem, alugado, haverá a rentabilidade dos cotistas. Portanto, se houver valorização, desvalorização, se o número de inquilinos diminuir, os cotistas arcarão com todos os ganhos e perdas, pois o conjunto formado pelos investidores passa a ser dono do imóvel, e esta posição os coloca diante dos desafios que a interface mobiliário/imobiliário apresenta. Se a opção for por um financiamento, não é de interesse da instituição financeira, num primeiro momento, ficar com o imóvel. Assim, não há a venda do imóvel. Esta instituição tem o interesse de receber o dinheiro emprestado e aplicado no negócio imobiliário com uma remuneração combinada (juros). Na falta de pagamento desta dívida, o imóvel pode passar a ser propriedade de tal instituição se dado como garantia da operação.

Como estamos no plano da análise das entrevistas, é interessante apresentar aqui como estes diferentes depoimentos trazem questões relativas à conjuntura políticoeconômica nacional articulada à macro-economia mundial. Assim, podemos observar como estes sujeitos apontam a relação existente entre ciclos econômicos e o setor imobiliário, demonstrando como este setor é sensível às oscilações conjunturais. É neste plano que podemos esboçar a relação entre o Estado, a economia e os interesses privados no contexto da internacionalização do setor imobiliário no movimento de uma economia financeira. No entanto, limitaremos nossa reflexão sobre a temática da influência da conjuntura na realização imobiliária e financeira à exposição, por ora, de alguns argumentos presentes nas falas dos entrevistados, de modo a nos deter a uma primeira aproximação com a questão.

A realização dos fundos no contexto político-econômico não ocorre sem conflitos entre os diversos agentes envolvidos. A esse respeito, a fala de Belleza nos transparece o sentido de enfrentamento e disputa quanto ao alcance de determinados interesses, relevantes para o avanço das atividades desse setor, denotando sua força corporativista, bem como o poder de organização e de formação de entidades de representatividade. Belleza também chama a atenção para um momento de aumento de investimento estrangeiro, que pode evidenciar uma internacionalização do setor imobiliário.

"Qual é o nosso cenário? Qual é o nosso predador natural? A taxa de juro. A alta taxa de juro é o maior competidor do empreendimento imobiliário, seja ele via FII, seja ele direto, como for, é o nosso grande problema. A taxa de 
juro no Brasil vem caindo, o risco Brasil, por conseguinte, vem caindo também. A nossa regulamentação de FII, de CRIs só vem melhorando. A nossa tributação hoje é mais justa, hoje nós temos isenção de imposto de renda pra pessoa física. Isso foi conseguido através de um ponto muito importante pra gente destacar que é a nossa Comissão de Desenvolvimento de Produtos Imobiliários junto à Bovespa, é dentro desta comissão que surge o projeto de isenção; essa comissão que está discutindo as melhorias na legislação dos CRIs. Esse movimento todo cria condições hoje com taxa de juro em baixa, risco Brasil caindo e regularização em ordem, base tributária bastante justa, nós estamos atraindo a atenção do resto do mundo. Nós estamos assistindo neste momento a chegada de vários grupos estrangeiros investindo no Brasil seja através de CRIs seja através de FII, porque o que eles conhecem lá de investimento imobiliário eficiente é através de FII. Se você quer investir, como eles chamam, equity (investimento direto), é FII, se é mercado de debit, que eles chamam, que é financiamento, o CRI nosso também já é bastante eficiente pra poder fazer isso".

Exatamente como Belleza, Machado afirma que esta fase é um momento de:

“Taxa de juros baixando, isenção para pessoa física, um instrumento popular, ou seja, a tendência é a utilização cada vez maior desse veículo como captação de recursos para o desenvolvimento de projetos imobiliários e a utilização de fundos imobiliários combinado com a utilização de CRI”.

A maneira como o setor imobiliário é atravessado pelos ciclos econômicos é aludida por Ventura:

“O mercado imobiliário, de alguma forma, ele é menos líquido que o mercado de ações, ele tem algumas características próprias que o tornam mais propício a ciclos. É um mercado de ciclos mesmo, acho que a questão dos imóveis comerciais aqui em São Paulo é bastante clara, pois existe uma percepção que há uma oportunidade, precisa-se de prédios comerciais ou de hotéis, de flats. Há uma percepção que existe uma necessidade de flats. Então chega uma hora que “oh! Precisa de flat, flat é um bom negócio” e vai todo mundo atrás de flat, aí todo mundo compra terreno, lança projetos, 
as pessoas compram participação nos flats. E os flats vão ficar prontos daqui a 3 anos e daqui a 3 anos muita água rolou, vai ver que a economia não cresceu tanto como se imaginava ou ninguém contava que iam surgir tantos flats. Tem alguns fatores e principalmente esse tempo de maturação, você decide construir um flat e até o flat ficar pronto muita coisa acontece, isso torna o mercado imobiliário bastante susceptível e é da natureza dele ser cíclico”.

A internacionalização do setor imobiliário surge em nosso trabalho a partir da observação do aumento do investimento estrangeiro nesse setor através das empresas internacionais que atuam em São Paulo e que aos poucos começam a aprofundar suas ações de incorporação e construção, a abertura de capital na Bolsa de Valores por parte das grandes companhias imobiliárias de São Paulo revelando uma grande participação dos investidores estrangeiros na compra de suas ações e as informações obtidas em nossas entrevistas da chegada de empresas imobiliárias estrangeiras, bem como grandes fundos de investimentos imobiliários. Questionado sobre o mercado de imóveis em São Paulo nos próximos anos, Belleza afirma:

“É um mercado muito mais profissionalizado, está atuando agora inclusive sobre a influência, inclusive, do investidor estrangeiro, nós já temos aqui Hines, Tishmam, hoje nós temos empresas nacionais capitalizadíssimas, temos ao mesmo tempo investidores chegando como é o caso do Equity International e mais alguns que estão aí no mercado, mas que nós não sabemos, mas estamos percebendo um movimento de compra muito grande, é um mercado muito rápido que vai crescer muito, está super aquecido e se ninguém atrapalhar vai crescer muito. Se ninguém voltar atrapalhar é taxa de juros voltar a subir e o governo não complicar, se deixar do jeito que está indo, está muito bom”.

Outro ponto importante na discussão da internacionalização é a existência de uma classificação que diz respeito às possibilidades de investimento em diferentes países, chamada de Investment Grade. De acordo com Belleza:

“Os bancos de varejo estão perdendo tempo. Estão chegando os grandes fundos imobiliários americanos aqui e vão dominar este mercado... nosso 
momento é de compra, porque nosso panorama está muito apetitoso para eles, as rentabilidades que dão aqui pra eles são muito boas e lá fora nós estamos vendo esgotar as possibilidades deles, o cenário deles está inflado, é um dinheiro que não gosta de investir uma hora em imóvel, outra hora em ouro é um dinheiro de imóveis, se lá os imóveis não estão indo bem serve pra onde está bom. Qual é a visão deles? O riso Brasil caiu, já tem negócio em bolsa, a inflação caiu, taxa de juro também está caindo, qual outro ponto que está seduzindo eles? O Brasil está para atingir o que eles chamam de Investment Grade, que é o nível a partir do qual você passa fazer parte da comunidade de investimento internacional, é a nota de classificação do país dada pelas agências de classificação de risco. Quando o México fez isso Há 4, 5 anos, quando ele conseguiu passar para o patamar de Investment Grade, o Brasil é sub, se o Brasil passar disso no México eles estão apostando nisso aí. O que aconteceu no México? Os preços dos imóveis dispararam”.

Esta idéia de internacionalização que trazemos em nossa análise pode revelar a realização deste capital estrangeiro específico no Brasil. No plano das hipóteses, existiria uma migração espacial destes capitais. O maior fundo de investimento imobiliário norte-americano, que somente investe em escritórios, possui um patrimônio de cerca de US\$17 bilhões. Este fundo chama-se Equity Offices e pertence ao grupo internacional Equaty International, que por sua vez é sócio da Gafisa em São Paulo e que está montando uma empresa no Brasil chamada Braço que pretende investir, além

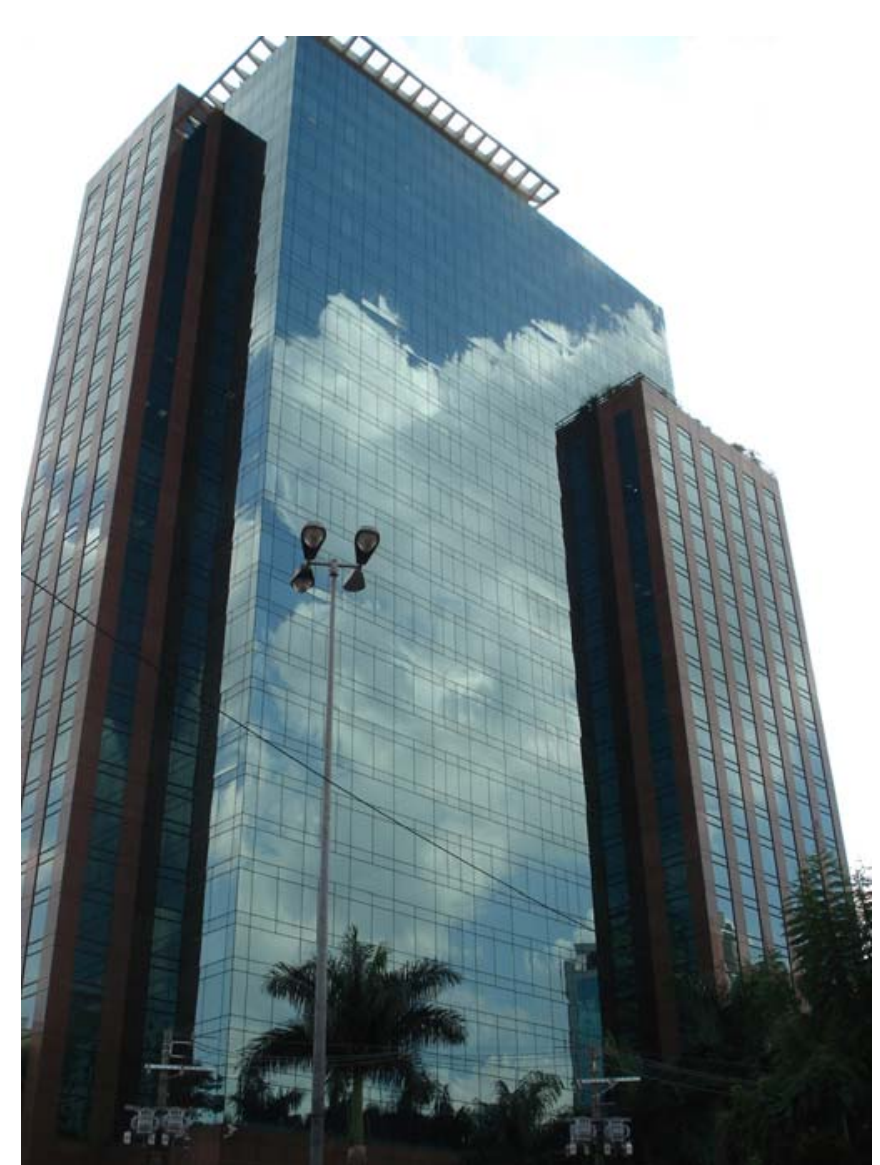
da área imobiliária, na área comercial.

\section{- O FII Financial Center}

O FII Financial Center foi estruturado entre a Cyrela e o Unibanco em 1999. Trata-se de um edifício de escritórios corporativos (triple A), localizado na esquina da avenida Juscelino Kubitschek e rua Bandeira Paulista no bairro do 
Itaim Bibi. Segundo Ventrura (administrador deste fundo), a Cyrela, empresa que construiu o prédio estava buscando nova forma de funding.

“A idéia era tentar explorar esse instrumento pra disseminá-lo e fazer de uma forma maior e um volume maior de operações, não era pra fazer esse simplesmente e ficar nisso. Então, a gente junto com Cyrela estabelecemos... começamos a imaginar como seria um fundo, como seria isso, qual seria o valor das cotas, o valor mínimo, qual seria o público a quem se destinaria, o que esse público gostaria e a gente chegou a conclusão que era um público que estava acostumado investir em imóveis comprando flats, por exemplo. Flat era uma coisa que a gente via como um mercado bastante perigoso, já havia um excesso de flats, então a gente queria dar a esse investidor uma outra oportunidade”.

Como podemos observar, o fundo foi estruturado com as características que o investidor de flat estava acostumado. $\mathrm{O}$ valor das cotas era em torno de $\mathrm{R} \$ 70$ mil e o pagamento das cotas poderia ser feito de forma parcelada.

“A princípio se buscou um desenho em que se venderia seis andares do prédio pra esse fundo e à medida que houvesse apetite dos investidores a gente poderia destinar mais andares, porque era tudo muito novo, ninguém testou isso. E a gente sabe que comprador de imóveis parece ser mais conservador. Então teria que ver se seria bem aceito essa idéia do sujeito comprar um papel que teria um lastro no imóvel; não é um imóvel propriamente dito. Se o sujeito quiser, ele compra uma pequena parte que equivale a uma parte [do imóvel] e se ele quiser levar a mesa dele, o computador e sentar naquela pequena parte ele não pode, ele não tem direito a usar o imóvel. Então teria que se ver a aceitação disso. Então se fez uma estrutura que a princípio venderia seis andares e poderia ir se juntando andares nisso a medida em que houvesse esse apetite. Na verdade o apetite até houve, vendeu bastante bem essas cotas, venderam bem rapidamente só que no momento que isso foi lançado já havia um apetite grande por esse tipo de empreendimento e até por outros tipos de investidores, então a Cyrela Brazil Realty que era dona do prédio no momento final resolveu destinar pro fundo imobiliário só esse seis andares. Então os outros andares foram vendidos para outros investidores e nem houve a chance de se 
engordar esse fundo com mais andares. A Cyrela quando nos procurou já era dona do terreno. Ela vendeu pro fundo uma fração do terreno. Ela vendeu uma fração desse terreno referente a 6 andares no total de 15 e vendeu as outras frações do terreno para os outros investidores. Então o terreno virou um terreno com vários proprietários, 6/15 do terreno pertencem ao fundo, aos cotistas do fundo, e os restantes 9/15 vão pertencer proporcionalmente ao que cada proprietário tem dos andares.

Quatro andares do fundo estão alugados para o Credcard, um andar para o BNP Paribas (um banco de investimento) e um outro andar para a consultoria Roland Berger. A administração do condomínio é feita pela empresa BRC administração e propriedades.

Apresentamos, em seguida, alguns dados referentes ao fundo imobiliário Financial Center. É interessante observar que o que compõe a diferença existente entre a receita de locação de imóveis e o lucro líquido do período são a depreciação dos imóveis alugados e as despesas operacionais.

Tabela 1 - FII Financial Center - 1 $^{\circ}$ semestre de 2006

\begin{tabular}{|l|r|}
\hline Receita de Locação de Imóveis (milhares de reais) & 2.132 \\
\hline Lucro Líquido (em milhares de reais) & 1.622 \\
\hline Quantidade de cotas & 38.763 .373 \\
\hline Lucro Líquido por cota (em reais) & 0.0418 \\
\hline
\end{tabular}

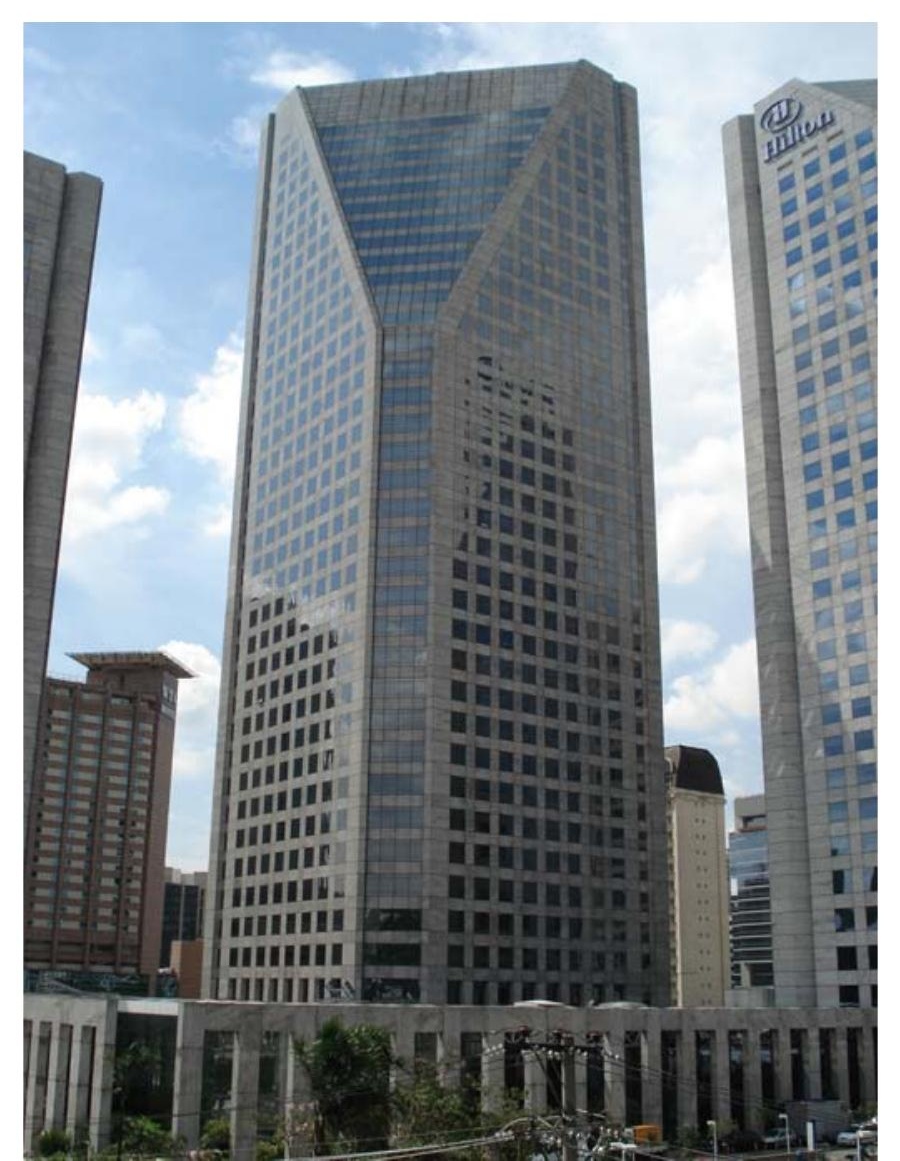

\section{- O FII Torre Norte}

Este projeto teve início com a Funcef (o fundo de pensão dos funcionários da Caixa Econômica Federal), a Tishman Speyer com a Método. Os três se uniram e desenvolveram o projeto de um complexo de escritório e hoteleiro em São Paulo, cujo o investimento seria como um todo da Funcef. O 
terreno foi comprado da Bolsa de Imóveis. A Tishman e a Método receberam uma participação no empreendimento de 16,17\%. Depois que o empreendimento já estava todo ocupado e em funcionamento, a Tishman e a Método resolveram reciclar este investimento. A partir daí, foi montado o fundo imobiliário pela Brazilian Mortgages e o Banco Ourinvest para vender os 16,17\% de participação das duas empresas. O objetivo delas era reciclar o investimento fazendo caixa para novos empreendimentos no Brasil (mais especificamente em São Palo). Houve a estruturação do fundo em 2001, que teve sua emisão de cotas no mercado, na qual foram vendidos os $16,17 \%$ da Tishman e da Método. Abaixo, a tabela 2 mostra alguns números do FIIs.

Tabela 2 - FII Torre Norte $1^{\circ}$ semestre de 2006

\begin{tabular}{|l|r|}
\hline Receita de Locação de Imóveis (em reais) & 21.317 .634 \\
\hline Lucro Líquido (em reais) & 11.452 .982 \\
\hline Quantidade de cotas & 3.935 .562 \\
\hline Lucro Líquido por cota (em reais) & 2,91 \\
\hline Total do ativo (em reais) & 326.805 .505 \\
\hline
\end{tabular}

O edifício Torre Norte é uma das torres do Complexo Empresarial Nações Unidas (CENU) e é localizado na Marginal do rio Pinheiros esquina com a avenida Roberto Marinho (antiga avenida Água Espraiada). Trata-se de um empreendimento triple A, administrado pela Tishman Speyer.

\section{- o FII Continental Square Faria Lima}

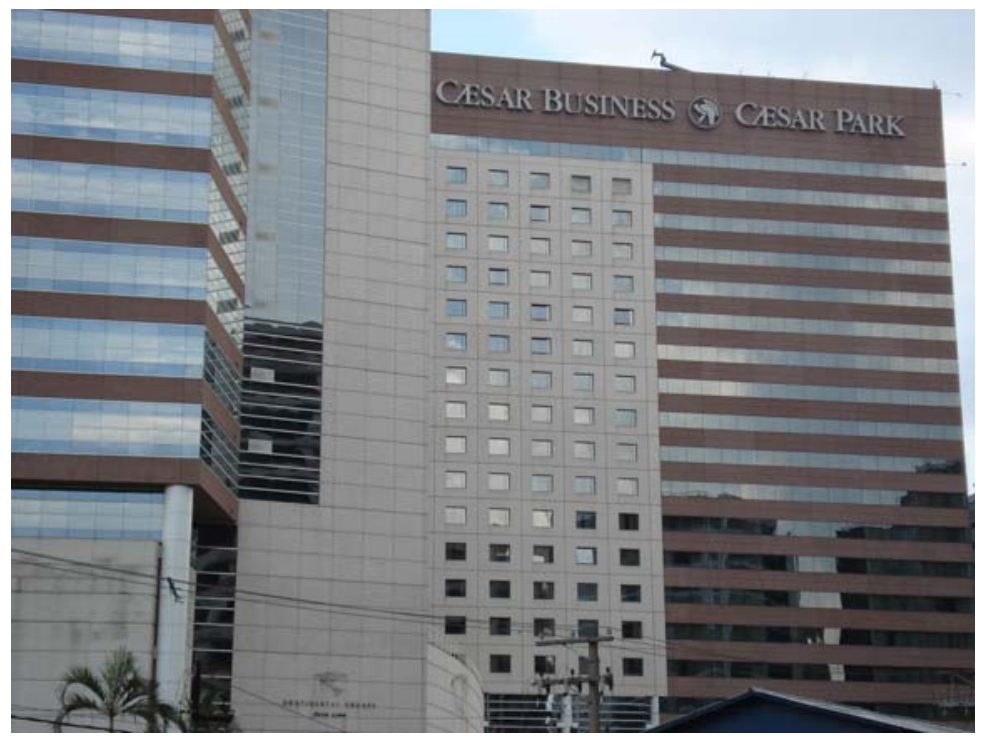


O projeto surge a partir de um terreno que era de propriedade da INPAR, localizado na rua das Olimpíadas no bairro da Vila Olímpia. A INPAR já tinha esse terreno já alguns anos e decidiu fazer ali um empreendimento multifuncional. A Unitas DTVM deu a idéia de estruturar uma operação de fundo imobiliário, vendendo-o no mercado e angariando fundos, ao invés de procurar investidores que poderiam aplicar dinheiro para que o projeto se concretizasse. O FII Continental Square Faria Lima serviu para captar recursos de funding quando o empreendimento ainda estava no chão. Sobre o projeto Kleinmam afirma:

\begin{abstract}
“o produto foi vendido como um conceito financeiro, com receitas imobiliárias, porque o cliente ia ser um cara imobiliário. Então a Lopes junto com a Unitas... A Unitas era a responsável final pela coisa, o financeiro e a CVM obriga que só uma empresa tenha o financeiro, mas o aconselhamento e a participação da imobiliária atrelada à Unitas era importante porque o cliente ia ser um cara que estava comprando um imóvel então nós fizemos dessa forma e tivemos um sucesso que eu reputo importante porque acho que é o único fundo que tem 830 cotistas, já foi bem, bem atomizado e tem cotistas que tem desde 7 milhões de cotas até cotistas que tem 20 mil cotas. A INPAR conseguiu quase R\$70 milhões para esse lançamento via esse sistema e hoje em dia esses cotistas estão auferindo a renda proveniente da exploração do Caesar Park e do prédio de escritórios, talvez com melhor ou pior sucesso, depende do momento”.
\end{abstract}

No caso deste fundo, a INPAR, para atrair o investidor, garantia aos cotistas durante dois anos uma renda mensal de 1\% ao mês (durante o período) em que o prédio estava em construção e mais $1 \%$ ao mês após o habite-se (durante dois anos operacionais). Segundo Belleza,

“essa compra é a compra me engana que eu gosto, porque você vende mais caro e devolve o dinheiro para o cara. É o seu dinheiro que ele cobrou mais caro ele vai te devolvendo aos poucos”.

Após 10 meses ou 14 meses (não temos a informação exata) a garantia foi paga e após esse período a INPAR não teve mais condições de realizar esse pagamento. A solução encontrada foi realizar este pagamento com as próprias cotas que a empresa 
tinha do fundo; uma oferta de aproximadamente cinco milhões de cotas. As cotas eram ativos que a empresa possuía e que não eram estranhos aos cotistas.

O empreendimento que é multi-uso, é composto por um hotel cinco estrelas, um hotel flat ${ }^{59}$, um prédio de escritórios e uma academia de ginástica Reebock. Além de salas de reuniões, auditórios para convenções, restaurantes e estacionamento. O fundo é dono de $75 \%$ do hotel (inclusive tudo o que tem dentro) e os 25\% restante é do grupo Posadas, detentor da marca Caesar Park. Com relação ao prédio de escritórios o fundo possui quatro andares e meio, a Petrus (fundo de pensão dos funcionários da Petrobrás) tem outros cinco andares, uma empresa de nome Quilombo possui mais um andar e outra empresa de nome AS tem meio. A Petrus também é dona de $10 \%$ das cotas do fundo (sete milhões de cotas). Sobre isso Kleinmam afirma:

"ela [a Petrus] tem propriedade via duas formas diferentes de ser proprietário. Isso é interessante como conceito. É um fundo de pensão que tem a propriedade do mesmo bem de duas formas diferentes”.

Mesmo assim, em nossas pesquisas nos perguntávamos qual seria a diferença entre participar de um fundo imobiliário e ao mesmo tempo ser proprietária de 5 andares dos quais receberia o aluguel sem intermediação nenhuma. De acordo com informações conseguidas em nossas entrevistas a Petrus é cotista do fundo porque recebeu cotas da INPAR como forma de pagamento referente a negócios imobiliários entre essas partes desconhecidos por nós. Segundo Belleza,

“Obvio que pra todo mundo, não só pra Petrus, era muito melhor só ser dono do prédio de escritório do que do fundo, porque o fundo só tem metade do conjunto de escritório e metade de um hotel esse é o problema”.

Abaixo os números do FII Continental Square Faria Lima.

Tabela 3 - FII - Continental Square Faria Lima $1^{\circ}$ semestre de 2006

\begin{tabular}{|l|r|}
\hline Receita de Locação de Imóveis (em milhares de reais) & 4.016 \\
\hline Lucro Líquido (em milhares de reais) & 2.276 \\
\hline Quantidade de cotas & 69.033 .500 \\
\hline
\end{tabular}

59 A existência de dois edifícios destinados à hospedagem no mesmo projeto, traz problemas à rentabilidade do fundo, pois o flat está sempre mais ocupado que o hotel cinco estrelas, que é parte do patrimônio do fundo. 


\begin{tabular}{|l|r|}
\hline Lucro Líquido por cota (em reais) & 0.0329 \\
\hline Total do ativo (em milhares de reais) & 65.918 \\
\hline
\end{tabular}

Fonte: CVM, 2006.

O empreendimento Continental Square Faria Lima é um empreendimento de grande porte e considerado pelo mercado como triple A. A região de São Paulo que concentra a maior quantidade de lançamentos de edifícios desse tipo é a região da Faria Lima, JK, Vila Olímpia e Berrini / Marginal Pinheiros. São prédios que contém em sua construção, infra-estrutura e maneira de funcionar alta tecnologia ${ }^{60}$.

Segundo Botelho (2005:12), o setor imobiliário “enfrenta uma grande dificuldade: a lenta obsolescência de seus produtos, dificultando a rotação do capital e o aumento da demanda de seu mercado. Essa obsolescência, dados os avanços tecnológicos externos ao setor da construção, pode ser acelerada criando um movimento constante de relocalização, destruição e reconstrução no e do espaço”. Articulando-se esta idéia ao movimento de expansão do eixo empresarial em São Paulo podemos afirmar que a construção contínua de novos empreendimentos cada vez mais tecnológicos seria uma possibilidade para manter esse capital em circulação. Assim, o setor imobiliário incorpora esses “avanços de tecnologia externos” para colocar no mercado opções cada vez mais atrativas ao funcionamento das empresas. Desta forma, é importante descrever sucintamente algumas características marcantes de como se estrutura o funcionamento destes complexos edifícios, porque a tecnologia empregada a essas construções impõe até novas relações de trabalho.

Como afirmamos anteriormente, o empreendimento Continental Square Faria, localizado no centro do bairro da Vila Olímpia é composto por um hotel cinco estrelas (Caesar Park), um hotel flat, uma torre comercial, uma academia de ginástica administrada pelo detentor da marca Reebock no Brasil, uma loja, que atualmente é alugada pela Caixa Econômica Federal, e um bolsão de estacionamentos. A torre comercial possui 17 andares, cada um com laje de $1.800 \mathrm{~m}^{2}$. Do $1^{\circ}$ ao 16 andares são escritórios e o $17^{\circ}$ andar é um pavimento técnico onde estão localizadas a subestação de energia elétrica e máquinas do ar-condicionado. Do $1^{\circ}$ ao $15^{\circ}$ andar, os pavimentos

\footnotetext{
${ }^{60}$ De acordo com a empresa Jones Lang LaSalle, um edifício triple A têm que possuir planta regular e flexível, pé-direito do piso ao forro de 2,70m, piso elevado, pé-direito do hall de entrada duplo e acabamentos nobres, fibra ótica, relação entre $\mathrm{n}^{\mathrm{o}}$ de vagas e área útil maior ou igual a uma vaga pra cada $35 \mathrm{~m}^{2}$, lajes em torno de $800 \mathrm{~m}^{2}$, elevadas especificações tecnológicas, completo gerenciamento e controle dos sistemas prediais (ar-condicionado, elétrica, hidráulica, segurança patrimonial e incêndio, elevadores e acessos) e heliponto.
} 
podem ser divididos em quatro conjuntos e o $16^{\circ}$ andar possui um conjunto só. $\mathrm{O} 1^{\mathrm{o}}$ andar é ocupado por quatro pequenas empresas e o restante do prédio por empresas de perfil corporativo, grandes empresas multinacionais. Então no $2^{\circ}, 3^{\circ}$, e $4^{\circ}$ andares está a empresa T Sistems; no $5^{\circ}$ andar está a INPAR e Amadeu; os $6^{\circ}$ e $7^{\circ}$ andares são ocupados pela Kimberly ClarK; a Comgás ocupa o $8^{\circ}$, $9^{\circ}$ e o $10^{\circ}$; a Diagio ocupa o $11^{\circ}$; no $12^{\circ}$ está a empresa Bank Company; o $13^{\circ}$ está vazio; metade do $14^{\circ}$ está ocupado pela construtora Triumpho; o $15^{\circ}$ está vago; no $16^{\circ}$ está a Acor do Brasil. A área privativa da torre comercial é de aproximadamente $27.000 \mathrm{~m}^{2}$. O hotel e o flat que possuem 17 andares cada um também possuem, no piso térreo, dois restaurantes cada. A academia possui $5.000 \mathrm{~m}^{2}$ e aproximadamente 3.000 alunos. Há quatro pavimentos no subsolo destinados às garagens, sendo que o $1^{\circ}$ e o $2^{\circ}$ são de uso do hotel, do flat, da loja e o bolsão de estacionamentos. $\mathrm{O} 3^{\circ}$ e o $4^{\circ}$ são destinados exclusivamente aos ocupantes da torre comercial.

Para administrar um empreendimento imobiliário deste tipo existem as empresas especializadas que prestam serviços certificados internacionalmente. Muitas vezes essas empresas contratadas já são estrangeiras. No caso deste complexo em específico a empresa administradora é a Jones Lang La Salle. Observamos que, nestes prédios, o funcionário que toma conta do edifício deixa de ser o zelador para ser gerente de condomínio com formação superior e especializações no currículo. No caso do Continental Square Faria Lima, o gerente de condomínio possui graduação em engenharia civil na Universidade Mackenzie, pós-graduação na área de administração financeira na Fundação Getúlio Vargas (FGV) e especialização em gestão empresarial na FIA. Como um property manager, ele é responsável pela gestão (gerenciamento operacional) de todo o complexo. Sua função é gerenciar todos os serviços de área comum do empreendimento, ou seja, fazer com que toda a infra-estrutura instalada funcione da melhor maneira. A área privativa das empresas não é de sua responsabilidade. Então podemos afirmar que a área de property management é responsável por gerir a propriedade (que será alugada) de um terceiro, no caso investidores, que compram cotas, conjuntos, andares para alugar para empresas. A coordenação da área privativa dessas empresas fica a seu cargo, contratando outras empresas ou mesmo a administradora do condomínio para realizar a tarefa que é conhecida neste mercado como gerenciamento de facilities.

No caso específico do Continental Square Faria Lima, a equipe de gestão, coordenada por Sérgio Maeda, é composta por outros quatro funcionários. Há um 
engenheiro contratado que coordena empresas de manutenção predial, manutenção do sistema de ar-condicionado ${ }^{61}$, elevadores, bomba de água. Esse engenheiro específico acompanha cada contrato firmado com essas empresas, que podem ser os fabricantes ou instaladores dos produtos (tempo de garantia) ou empresas terceirizadas que oferecem manutenção técnica a esses equipamentos. Há outro funcionário que atua na supervisão de contratos de empresas especializadas que oferecem serviços de recepção, portaria, limpeza, jardinagem, segurança e estacionamento. Para a prestação desses serviços 110 pessoas trabalham na torre comercial, sem contar o flat e o hotel. Outros dois funcionários realizam todo o controle financeiro e administrativo.

Este complexo conta ainda com um sistema de poço artesiano para captura de água no subsolo do terreno que pode ser utilizada pelo complexo todo sem custos. Os custos são referentes à instalação, regulamentação funcionamento e manutenção do sistema. Ou seja, é instalado um hidrômetro autorizado pela SABESP que vai separar o que entrou de água (não há taxas, pois a água recolhida do poço) e o que sai como esgoto é tarifado. Essa água é tratada no subsolo do próprio prédio em uma estação de tratamento de água lá instalada. No caso deste empreendimento em questão os últimos testes estão sendo realizados para que o sistema comece a funcionar, diminuindo assim o preço do condomínio que é hoje de R\$12,50 para cada $35 \mathrm{~m}^{2}$.

A partir desta descrição observamos que o funcionamento deste tipo de imóvel se encontra imerso numa rede de serviços administrativos e burocráticos que vai permeando e transformando as relações de trabalho. Essas novas relações de trabalho passam, em alguns casos, a exigir cada vez mais uma especialização do funcionário e em outros, mais tarefas específicas surgem na vida do trabalhador que realiza serviços que exigem menos qualificação. Ainda mais quando se trata de um ambiente de trabalho no qual novas tecnologias estão sendo incorporadas. O gerente de condomínio tem que possuir curso superior e especializações na área de finanças e administração, tem que falar pelo menos mais de um idioma além do português e lidar com diversas empresas prestadoras de serviços diferenciados. No outro extremo, estão os trabalhadores terceirizados das empresas de segurança, limpeza, estacionamento, que executam tarefas

\footnotetext{
${ }^{61} \mathrm{O}$ sistema de ar-condicionado é composto por três máquinas localizadas no pavimento 17 , chamadas schiller, que fazem com que a água fique gelada. Está água gelada é distribuída pelos andares que possuem um equipamento que insufla ar sobre essa água gelada; então este ar gelado é distribuído em cada andar. Como cada pavimento possui conjuntos e salas, a distribuição deste ar-condicionado é controlada por um sistema de automação predial que controla a quantidade de ar que vai ser insuflada para cada um dos ambientes e ele também consegue controlar a temperatura da água que deve ser oferecida para cada andar. O funcionamento sincronizado deste equipamento depende de grande tecnologia e não depende de mão de obra para fazer toda a manutenção do sistema.
} 
específicas e estão imersos num mercado de trabalho em que podem ser destinados as trabalhar em qualquer outro lugar a qualquer hora; estão imersos num mundo do trabalho em que a flexibilização do trabalho e dos direitos trabalhistas batem a sua porta, vivendo a negatividade do trabalho.

A inovação tecnológica cria novos segmentos na indústria da construção civil, além de todo um mercado voltado para decoração, design jardinagem, móveis. A incorporação de novas tecnologias de construção civil e automação predial pelo mercado imobiliário vem trazer fôlego ao desenvolvimento desta indústria, que ao acompanhar as inovações tecnológicas de outro setores mantêm o capital no processo produtivo, em circulação, ou seja, a inovação tecnológica pode fazer com o que o tempo de realização dos capitais aí aplicados sejam menores, isto é uma obsolescência mais rápida dos imóveis criando uma nova demanda por espaços novos. Essa dinâmica possui uma relação com o processo de reprodução do espaço do urbano, pois vai revelar um movimento de valorização - desvalorização - revalorização do espaço bem como um movimento de construção - desconstrução - reconstrução da forma da cidade. Por outro lado, esse processo também vai revelar que há limites geográficos para a expansão imobiliária bem como limites de propriedade e limites econômicos como, por exemplo, uma super oferta de estoque de imóveis para escritórios.

As fotos a seguir mostram os interiores desses prédios, bem como algumas das tecnologias utilizadas. 
INTERIORES DE EDIFÍCIOS
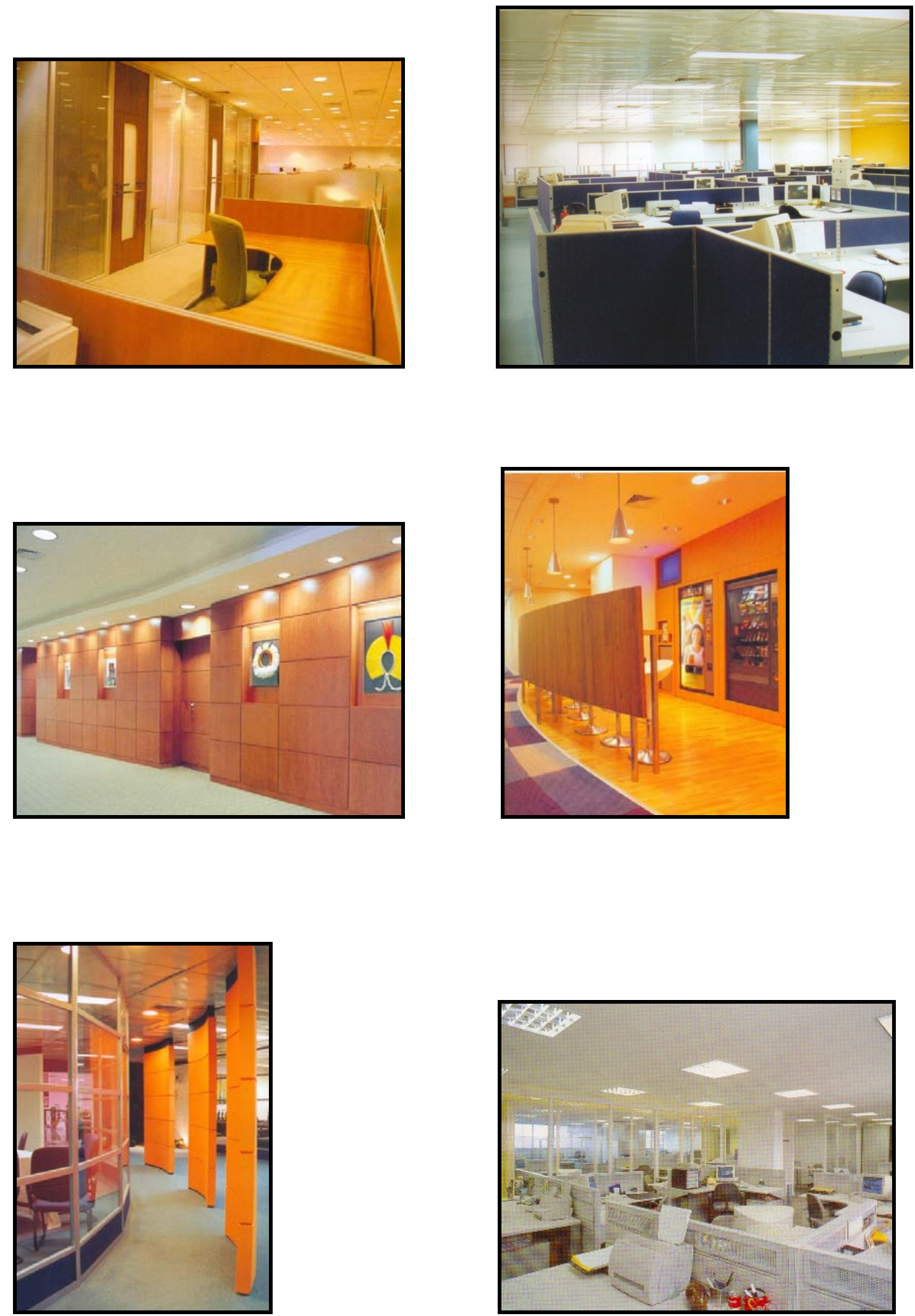


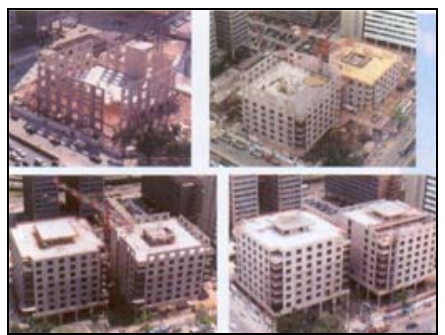

Construção de um edifício - Sistema Tilt-up.

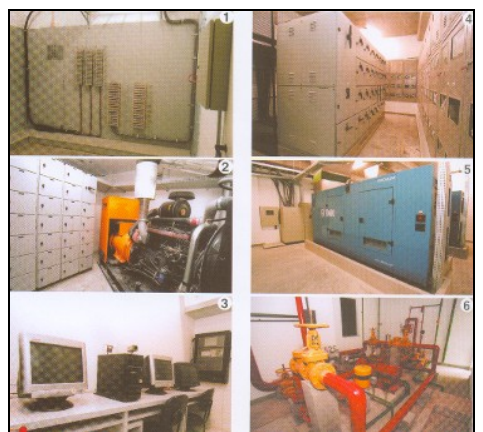

Fotos 01 e 02. Instalação dos geradores e telefonia. Fotos 03, 04, 05 e 06. Central de monitoramento, instalações elétricas, grupo gerador e de incêndio.

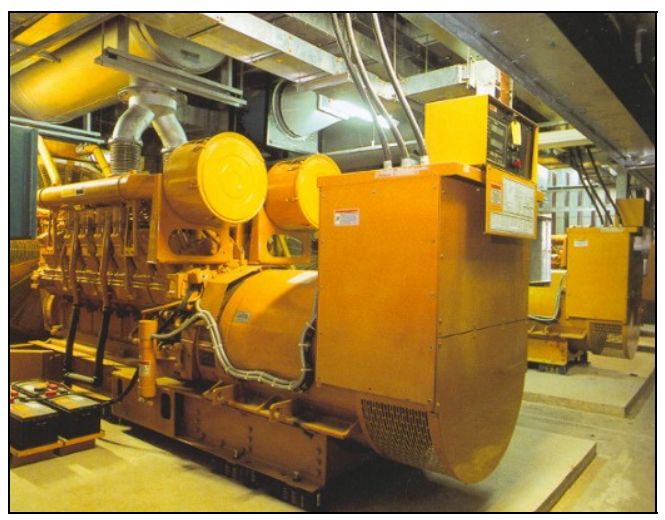

Sistema de geração própria de energia de 2000 KVA cada.

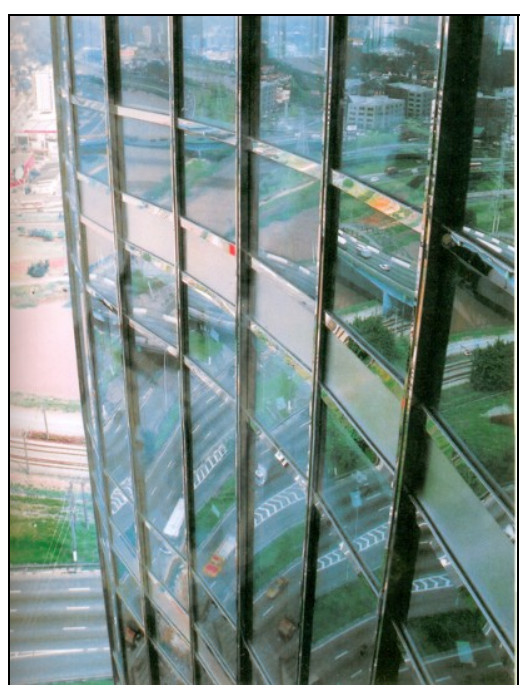

Fachada de vidros. 


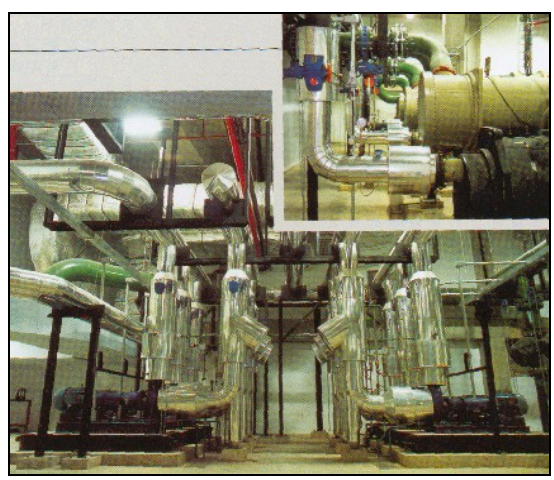

Sistema de ar condicionado - VAV.

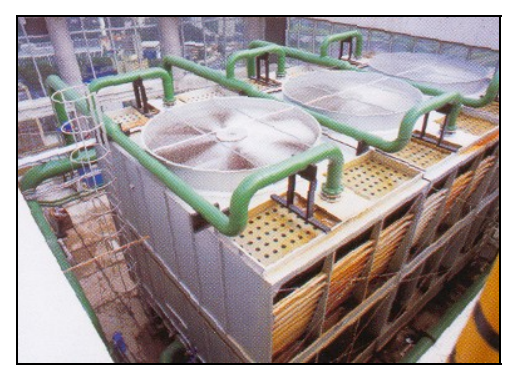

Sistema de ar condicionado - VAV.

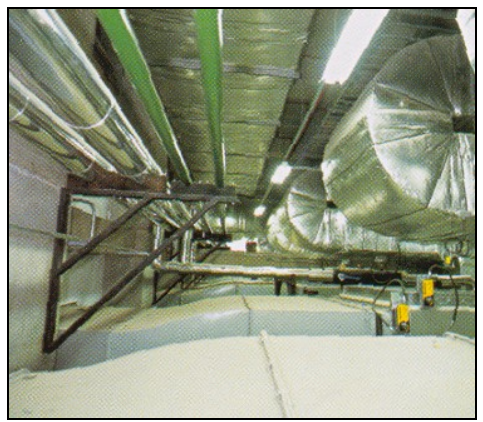

Sistema de ar condicionado - VAV. 


\section{Capítulo 3}

\section{As empresas imobiliárias e a abertura de capital na bolsa de valores}

O mercado imobiliário no ano de 2006, presenciou a abertura de capital na Bovespa realizada pelas maiores empresas empreendedoras imobiliárias de São Paulo (empresas que trabalham com imóveis de médio e alto padrão); tais como Cyrela, Gafisa, Rossi, Company, entre outras que estão também dando início a esse processo. Esse é um momento de reprodução de um mercado imobiliário crítico. Esses pequenos capitais estão se valorizando, mas enfrentando a todo momento a situação crítica do capitalismo mundial, que em termos de acumulação encontra-se em uma crise que se estende desde os anos 70. Além do que, estamos tratando aqui de formas de financiamento da construção civil e como já discutimos no capítulo 1, surge como um obstáculo a reprodução do capital no setor imobiliário.

Trata-se de um processo de captação de recursos a baixo custo para a realização de incorporação, compra de terrenos e lançamentos imobiliários bem como aquisição de outras empresas deste ramo que sejam proprietárias de terrenos e que detenham empreendimentos já lançados no mercado que interessem a esses grandes empreendedores. É importante destacar que o montante de capital absorvido por essas empresas não são utilizadas para a construção de novos empreendimentos. A construção ainda continua sendo financiada pelo Sistema Financeiro da Habitação (SFH). A captação de recursos através de vendas de ações em bolsa aumenta o patrimônio da empresa e permite também que seu crescimento e lucro cresçam consideravelmente, o que permite que ela consiga mais dinheiro junto ao SFH para realizar a construção dos empreendimentos imobiliários. Assim, a grande aplicação desses recursos é em compra de terrenos e incorporações imobiliárias.

Segundo reportagem da Folha de São Paulo ${ }^{62}$, no ano de 2006, o setor imobiliário liderou a abertura de capital na bolsa de valores. Esses negócios representaram 50\% do montante de R \$ 8,83 bilhões emitidos em ações em 2007. De 17 emissões realizadas em 2007, 11 eram da companhia do setor.

A tabela a seguir mostra os dados de participação de investidores estrangeiros na distribuição pública de ações em 2006.

\footnotetext{
${ }^{62}$ Folha de São Paulo, 28/03/2007.
} 
TABELA 11

Distribuição Pública de ação em 2006
Participações dos investidores estrangeiros
\begin{tabular}{|l|c|c|c|}
\hline \multicolumn{1}{|c|}{ Empresa } & Volume total & \multicolumn{2}{c|}{ Volume estrangeiro } \\
\hline & da distribuição & \multicolumn{2}{c|}{ na oferta total } \\
\hline & R & & $\begin{array}{c}\text { Part. } \\
\text { (\%) }\end{array}$ \\
\hline Gafisa & $926.988 .750,00$ & $669.685 .366,50$ & 72,24 \\
\hline Company & $281.600 .000,00$ & $179.150 .400,00$ & 63,62 \\
\hline Rossi Res. & $1.012 .500 .000,00$ & $812.964 .050,00$ & 80,29 \\
\hline Cyrela & $837.947 .500,00$ & $632.505 .576,50$ & 75,48 \\
\hline Abyara & $163.770 .250,00$ & $150.416 .250 ., 00$ & 91,85 \\
\hline Klabin Segall & $527.347 . .500,00$ & $362.666 .775,00$ & 68,77 \\
\hline Brascan Res. & $1.188 .000 .000,00$ & $1.038 .857 .600,00$ & 87,45 \\
\hline
\end{tabular}

Fonte: Bovespa, 2007

Como podemos observar na tabela 11 os investimentos estrangeiros são responsáveis por comprar mais de 50\% das ações emitidas na bolsa pelas companhias em questão. Segundo Tolosa ${ }^{63}$, a maior parte dos investidores que compraram ações dessas empresas são investidores estrangeiros. Elemento que reforçar nossa idéia de internacionalização do setor imobiliário em São Paulo.

Para o debate, trazemos um depoimento de Belleza sobre esse tema, o qual nos instigou a incorporar este assunto em nossa pesquisa.

“Está se criando uma super liquidez neste mercado o que vai fazer com que a produção imobiliária aumente uma barbaridade e causa alguns efeitos bastante interessantes, como por exemplo, uma das coisas fundamentais é terreno, terreno virou ouro em pó. O que adianta se você tem muito dinheiro e não tem onde construir? Quem está bem posicionado com terreno, isso é fundamental. Está muito mais fácil arrumar capital do que arrumar terreno, aposto com você. Dinheiro todo mundo pode ter, terreno nem todo mundo tem”.

Para nossa pesquisa em Geografia Urbana, Belleza traz a temática da importância que o espaço (o solo urbano) possui hoje na realização desses capitais que estão procurando rentabilidade no setor imobiliário. Tolosa, ao ser questionado sobre a importância de possuir terreno num momento que parece haver uma escassez diz que

\footnotetext{
${ }^{63}$ Diretor da empresa Company S.A., em entrevista realizada pelo autor.
} 
terreno não era o grande problema, havia possibilidade de construir em vários lugares da região metropolitana.

Retomando uma idéia já posta em evidência no texto deste trabalho, mas de suma importância observamos que especificamente o mercado de edifícios corporativos e edifícios residenciais, especificidades em sua construção e realização na cidade. Os edifícios de escritórios, bem como o setor hoteleiro e flats não podem se localizar fora da expansão do eixo empresarial de São Paulo (são atividades que dependem dessa centralidade); são empreendimentos que dependem muito mais da conjuntura econômica, de ciclos econômicos o que vai refletir no valor da terra, do aluguel, na taxa de vacância no mercado. Portanto, havendo a necessidade de concentração espacial desses empreendimentos no fragmento aqui em questão, há uma maior escassez para sua construção. De forma um pouco diferente, o setor imobiliário voltado para empreendimentos residenciais, ou seja, moradia, não depende desta localização estrita, ele pode se realizar em vários lugares da metrópole (mas não em qualquer lugar) principalmente com empresas muito capitalizadas como estão a oferta de terrenos tornase mais ampla.

Os mapas a seguir revelam a localização dos terrenos adquiridos pela empresa Company neste ano de 2006 após IPO (sigla em inglês que significa abertura de capital em mercado secundário) e os lançamentos residenciais na cidade de São Paulo em 2006 (mapa 6).

O mapa 5 revela que os terrenos adquiridos pela Company após o IPO, se localizam em várias regiões da cidade e não em qualquer lugar, além do que a maior parte deles está nas bordas do eixo empresarial da metrópole, ou seja, no vetor sudeste da cidade de São Paulo.

O mapa 6 mostra que os lançamentos residenciais estão espalhados pela cidade, com certas manchas de concentração no vetor sudoeste e por exemplo no Tatuapé, o que pode nos apontar que o setor imobiliário residencial também possui sua áreas de concentração espacial. É interessante comparar o mapa 6 com o mapa 4, que revela a concentração espacial dos edifícios de escritórios em no eixo empresarial. Desta forma, afirmamos que são estratégias diferentes que o mercado de edifícios comerciais utiliza com relação ao mercado residencial, além do que o residencial está muito mais próximo do valor se uso que os imóveis podem oferecer e o comercial muito mais ligado ao valor de troca. Porém ambos estão imersos na lógica da acumulação capitalista. 
MAPA 5

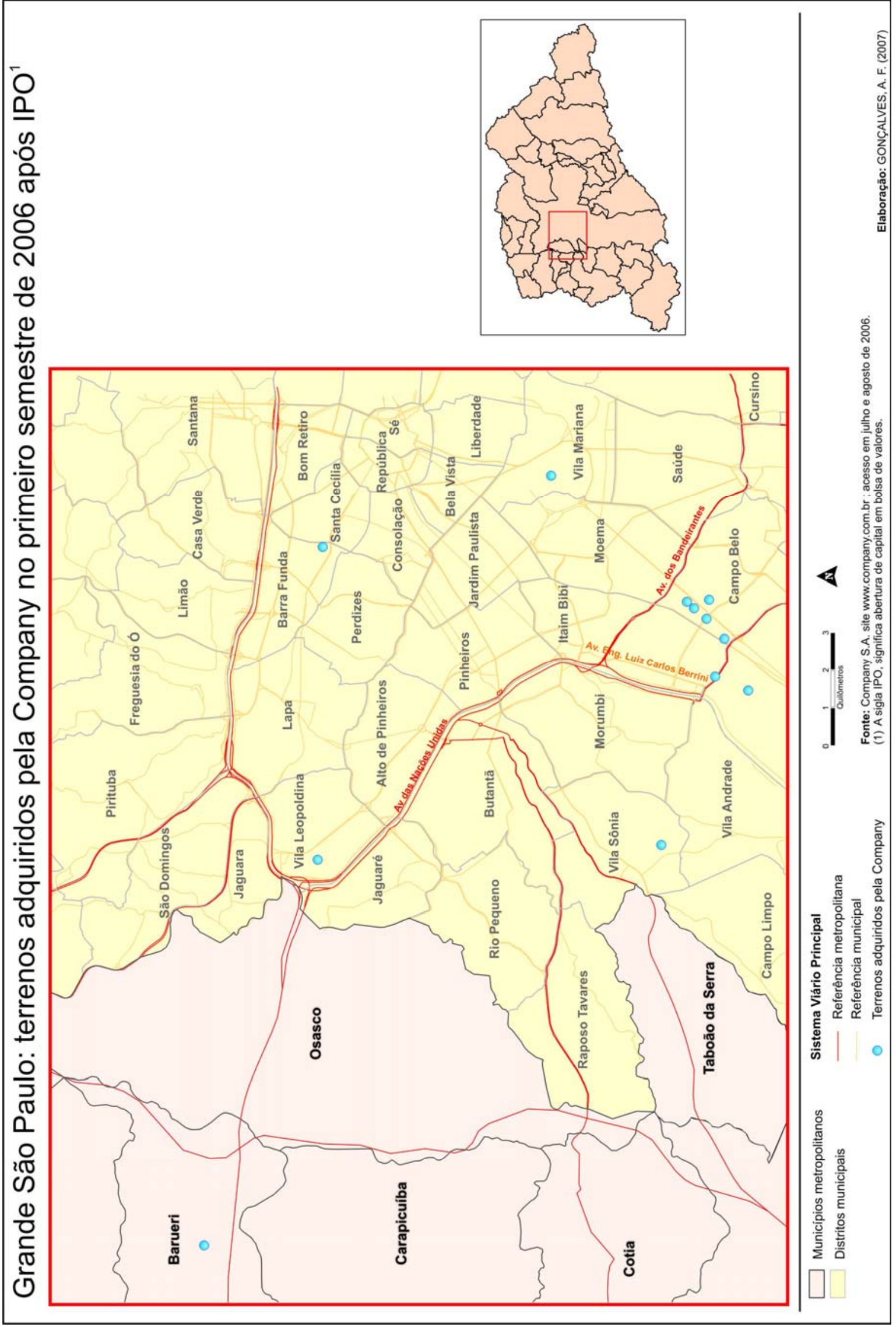


MAPA 6

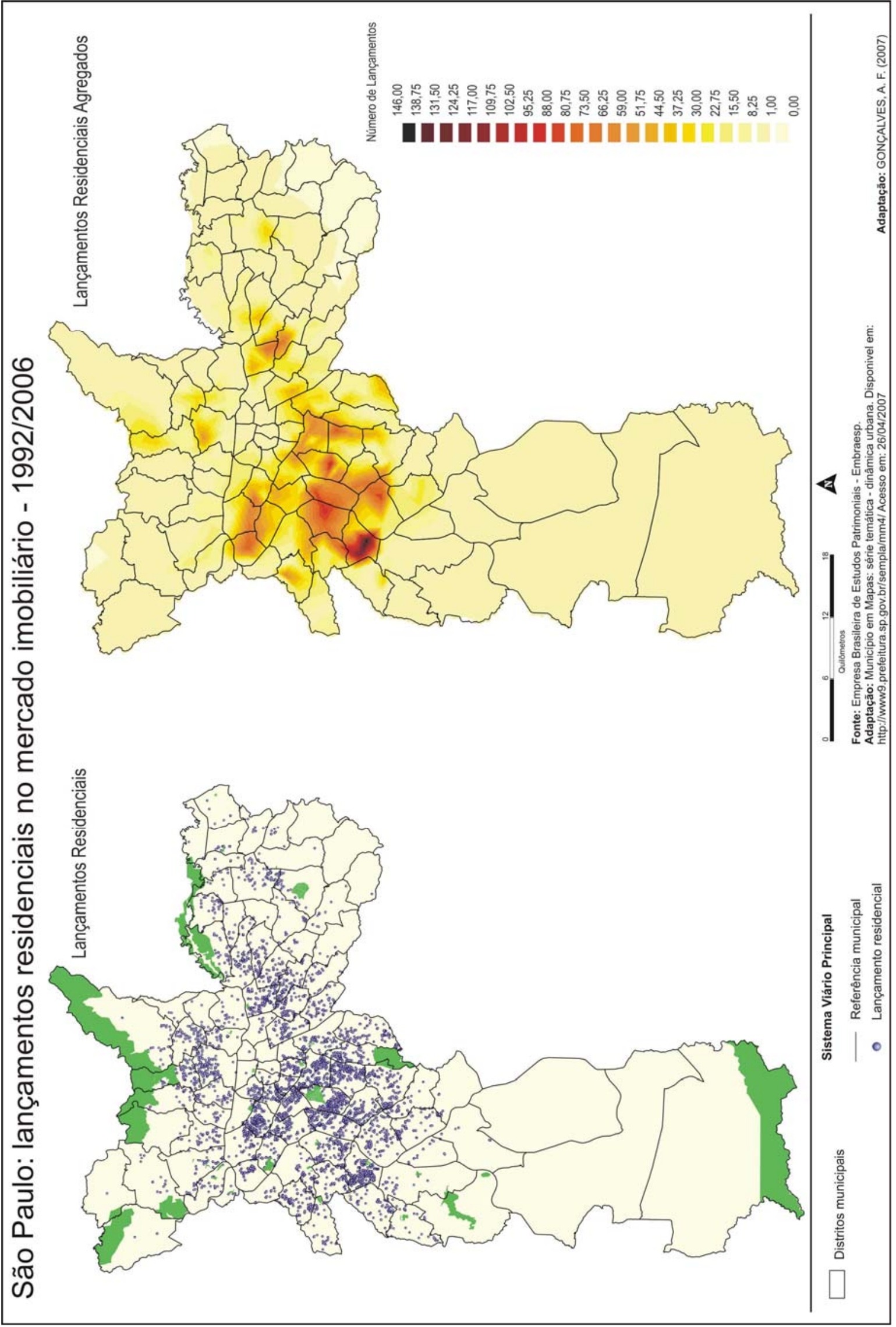


Esse mecanismo de financiamento ao setor imobiliário vem se tornando uma saída para as grandes empresas empreendedoras imobiliárias para atrair recursos para o desenvolvimento de seus negócios. Entretanto, a busca intensa a esse mecanismo pode trazer um saturamento ao setor, o que indica um caminho no sentido da crise. Como já nos mostraram outros países, esse pode ser um caminho para o que se chama de bolha imobiliária, como escreveu Kurz “a bolha financeira imobiliária como adiamento da crise”, vamos ver até quando. 


\section{CONSIDERAÇÕES FINAIS}

Todos esses serviços e formas de investimentos apontados aqui, nos revelam que a reprodução capitalista se realiza hoje na metrópole produzindo um espaço altamente especializado, tecnicizado, que garanta a mobilidade de fluxos materiais e imateriais, que aparece enquanto produção do "moderno", uma condição para o avanço e desenvolvimento do modo de produção capitalista que se constitui enquanto totalidade mundial. Também, a nosso ver estamos diante de uma especialização da espacialização, que se expressa em todo eixo empresarial de São Paulo.

Pensar a respeito da espacialização é nos colocar diante de um processo que ocorre materialmente no espaço, retomando assim a produção social deste espaço e o que ela significa. É nos colocarmos diante da divisão sócio-espacial e técnica do trabalho num contexto em que está ocorrendo uma transformação nos moldes de acumulação capitalista. O que provoca transformações no processo de constituição do espaço urbano. Esses novos moldes de acumulação nos colocam diante de desafios para pensar a respeito de um espaço cada vez mais modificado, que caminha na direção de atender a especialização das funções, do mercado e da própria divisão sócio-espacial do trabalho. Num primeiro momento, refletir sobre a espacialização nos coloca diante da localização espacial e posteriormente do conteúdo do processo. Desta forma, “..a localização de uma atividade só poderá ser entendida no contexto do espaço como um todo, na articulação da situação relativa dos lugares...” (Carlos, 1994:86-87). Porém, ao pensarmos nas atividades que estão em questão - atividades modernas do terceiro setor da economia -, elas tem que ocorrer num determinado lugar da cidade o que requer um outro espaço para a acumulação (Carlos, 2001); no sentido de como afirmamos no capítulo 1, isto é, a articulação entre os interesses de uma burguesia e do Estado que vêem no espaço da cidade a possibilidade de reproduzir seus interesses. Por isso afirmarmos que existe uma espacialização da especialização: é o escritório que sai da planta da fábrica e vai para os grandes edifícios, é diminuição do chão de fábrica, é a especialização da divisão sócio-espacial e técnica do trabalho (ganhando novos contornos) e do conhecimento. É a adequação, produção e especialização de espaços da cidade para o desenvolvimento do capitalismo moderno. Estamos frente à importância estratégica que o espaço possui nos dias atuais.

Esse processo posto em discussão pode nos apontar o entendimento de que o comando da reprodução do capitalismo está concentrado na valorização e acumulação 
do capital financeiro. Num primeiro momento, ou melhor em uma economia altamente baseada na produção industrial, o setor imobiliário aparece como possibilidade de realização de investimentos e também como reserva de valor em momentos de crise, sendo ainda a produção industrial responsável pela maior parte da mais-valia global. No momento atual, o setor imobiliário parece assumir um papel central na acumulação, pois, do ponto de vista da realização do capital, estamos diante da procura de caminhos para a mobilização do imobiliário. Observamos que na cidade de São Paulo os investimentos financeiros começam a se atrelar cada vez mais ao setor imobiliário. Existe no horizonte um grande desafio de construir um caminho que aponte o lugar de formação de capital, ou seja a realização da mais-valia.

Um ponto a ser destacado é que as entrevistas revelam que a reprodução desses capitais é crítica, pois necessitam reinventar, a todo momento, novas maneiras de se realizarem (aqui o imobiliário aparece como saída e a mobilidade como condição). Entendemos que vivemos um momento de crise do sistema de acumulação, entretanto é interessante ressaltar que esses capitais individuais não estão, eles, de alguma forma, se realizam.

Acreditamos que o desenvolvimento de nossa pesquisa pode reforçar a pertinência de nossa hipótese central. O capital financeiro investe nos FIIs e nas empresas empreendedoras imobiliárias apostando que seus negócios com a terra urbana e a produção do espaço poderá lhe oferecer a valorização do capital investido. Assim, a produção do espaço se torna condição e meio para a realização desses capitais. Observamos também que está sendo aberto um caminho à internacionalização deste setor pela presença dos investidores e empresários deste ramo na cidade de São Paulo, o que pode revelar uma migração espacial de capitais vindo de outros países que encontram mais uma possibilidade para sua valorização.

Retomamos aqui num outro patamar a idéia da reprodução crítica do capital e a crise inerente à realização do capital. Mesmo se reproduzindo criticamente, esses momentos críticos são possibilidades da expansão do próprio capital. Na realidade, se trata de um momento em que pode ocorrer uma diminuição do ritmo da atividade imobiliária ou uma superação que abre caminhos para a sua reprodução. O que é necessário para racionalidade do capital é sua permanência no processo de produção e sendo investido para sua realização enquanto capital.

Aqui deixamos em aberto algumas possibilidades. Pode acontecer uma expansão da construção para as regiões mais periféricas, lugar onde o preço da terra é mais baixo; 
imobilização de grande quantidade de capital realizando um estoque de terreno, mas esta é uma opção que pode frear o processo do capital. As empresas construtoras e empreendedoras imobiliárias que abriram capital na bolsa estão utilizando dessa estratégia, porém não parece que estão formando estoque de terra, pois como estão capitalizadas podem construir, “mas para quem?”, aí entra a questão da demanda, que se não for suficiente, o caminho da desvalorização está aberto. Outra possibilidade é produzir menos nas áreas mais valorizadas da cidade, que são os lugares de maiores infra-estrutura.

Este tema se mostra como uma temática extremamente geográfica, pois estamos diante dos limites geográficos da produção do capital. Articulamos o plano da localização ao da produção espacial da cidade, análise necessária para alcançarmos os conteúdos dos processos.

O que se abre para o pensamento são as conseqüências deste processo para a urbanização contemporânea e a importância de uma economia política do espaço para refletirmos o papel do imobiliário nos mecanismos gerais da economia capitalista. Este é um caminho possível, os desafios terão que ser enfrentados por nós. 


\section{Bibliografia}

ARRIGHI, G. O longo século XX. São Paulo, Contraponto/Unesp, 1996.

BAUMAN, Z. Globalização. Rio de Janeiro, Jorge Zahars Editor, 1999.

. Modernidade Líquida. Rio de Janeiro, Jorge Zahars Editor, 2001.

BENSAÏD, D. Cambier el mundo. Madid, Catarata, 2004.

BOTELHO, A. O financiamento e a financeirização do setor imobiliário: uma análise da produção do espaço e da sócio-especial através do estudo do mercado da moradia na cidade de São Paulo. Tese de Doutorado em Geografia Humana, FFLCH/USP, 2005.

CALADO, L. R.; GIOTTO, R. M.; SECURATO, J. R. “Um Estudo Atual sobre Fundos de Investimentos Imobiliários”. In: Anais da V SemeAd. São Paulo, FEA-USP, 2001.

CAPEL, H. "Redes, chabolas y rascacielos. Las transformaciones físicas y la planificación en las áreas metropolitanas”. In: Actas del Seminario Internacional El desafío de las áreas metropolitanas em um mundo globalizado. Una mirada a Europa y América Latina. Barcelona, 2002.

CARLOS, A. F. A. A (Re)produção do Espaço Urbano. São Paulo, Edusp, 1994.

. O lugar no/do mundo. São Paulo, Editora Hucitec, 1996.

. Espaço-Tempo na Metrópole. São Paulo, Contexto, 2001.

"São Paulo: do capital industrial ao capital financeiro". In: CARLOS, A. F. A. e OLIVEIRA, Ariovaldo Umbelino de (orgs.). Geografias de São Paulo: a metrópole do século XXI. São Paulo: Contexto, 2004.

CHAUÍ, M. O que é ideolgia. São Paulo, Editora Brasiliense, 2005. 
CHESNAIS, F. (org.). A Mundialização Financeira. São Paulo, Xamã, 1999.

CICCOLELLA, P. "La metrópolis postsocial: Buenos Aires, ciudad-rehén de la economía global”. In: Actas del Seminario Internacional El desafío de las áreas metropolitanas em um mundo globalizado. Una mirada a Europa y América Latina. Barcelona, 2002.

COSTA, W. M.; MORAES, A.C. R. A Valorização do Espaço. São Paulo, Editora Hucitec, 1999, $4^{\text {a }}$ ed.

CORDEIRO, H. K. O centro da metrópole paulistana-expansão recente. São Paulo, USP-IG, 1980.

CRUZ, M. M. N. Estado, espaço e acumulação na crise contemporânea. Dissertação de Mestrado em Geografia Humana, FFLCH/USP, 2006.

DAMIANI, A. L.; CARLOS, A. F. A.; SEABRA, O. C. L. (orgs). O espaço no fim do século: a nova raridade. São Paulo, Contexto, 1999.

DAMIANI, A. L. “A Propósito do Espaço e do Urbano: Algumas Hipóteses”. In: Revista Cidades, n 1, pp. 79-95. Presidente Prudente, 2004.

FARNETTI, R. “O Papel dos Fundos de Pensão e de Investimentos Coletivos Anglosaxônicos no Desenvolvimento das Finanças Globalizadas”. In: CHESNAIS, F. (org.). A Mundialização Financeira. São Paulo, Xamã, 1999, pp.183-210

FERREIRA, J. S.W. São Paulo o mito da cidade global. Tese de Doutorado, FAU-USP, 2003.

FIX, M. Parceiros da Exclusão. São Paulo, Boitempo Editorial, 2001.

São Paulo cidade global. Fundamentos Financeiros de uma miragem. Dissertação de Mestrado. FFLCH - USP, 2003. 
FRÚGOLI, H. Centralidade em São Paulo. São Paulo, Editora Cortez, Edusp/Fapesp, 2000.

FUJIMOTO, N. A. A produção monopolista do espaço urbano e a desconcentração de terciário de gestão na cidade de São Paulo: O caso da avenida Eng. Luís Carlos Berrini. Dissertação de Mestrado. FFLCH - USP, 1994.

GRESPAN, J. L. O negativo do capital. São Paulo, Editora Hucitec, 1999.

GUTTMANN, R. “As mutações do Capital Financeiro”. In: CHESNAIS, F. (org.), A Mundialização Financeira. São Paulo, Xamã, 1999, pp.61-96.

HAESBAERT, R. Territórios Alternativos. São Paulo, Contexto, 2002.

HARVEY, D. The limits to capital. Oxford, Basil Blackwell, 1984.

. Condição Pós-moderna. São Paulo, Edições Loyola, 1992.

. Justice, Nature \& the Geography of Difference, Oxford, Blackwell Publishers, 1999.

. O novo imperialismo. São Paulo, Edições Loyola, 2004.

. Espaços de Esperança. São Paulo, Edições Loyola, 2004.

. A produção capitalista do espaço. São Paulo, Annablume, 2005.

HOLLOWAY, J. Mudar o mundo sem tomar o poder. São Paulo, Viramundo, 2003. 
JAMESON, F. A cultura do dinheiro. Ensaios sobre a globalização. Petrópolis, Editora Vozes, 2001.

KURZ, R. A segunda bolha financeira. A bolha financeira imobiliária como adiamento da crise. Publicado em Neues Detschland, Berlin, junho de 2003.

http://obeco.planetaclix.pt/rkurz137.htm site acessado em 22/08/2006.

LEFEBVRE, H. A Re-produção das Relações de Produção. Publicações Escorpião, Porto, Portugal, 1973.

. La Production de L'Espace. Paris, Anthropos, 2000.

. Espacio y Política. El derecho a la ciudad II. Barcelona, Ediciones Península, 1976.

. O Direito à Cidade. São Paulo, Editora Moraes, 1991.

. A Revolução Urbana. Belo Horizonte, Editora UFMG, 1999.

. De l'Etat, Tomo III e IV. Paris, Union Générale d'Éditions, 1976-1978.

LENCIONI, S. "Reestruturação urbano-industrial no Estado de São Paulo: a região da metrópole desconcentrada”. In: SOUZA, M. A. A. et al (orgs.). Território Globalização e Fragmentação. São Paulo, Hucitec/ANPUR, 1996, pp.198-210.

- “Cisão Territorial da Indústria e Integração Regional no Estado de São Paulo”. In: GONÇALVES, M. F.et al (orgs.), Regiões e Cidades, Cidades nas Regiões. O desafio urbano-regional. São Paulo, Editora da Unesp/ANPUR, 2003, pp. 465-475.

MATTOS, C. de. “Santiago de Chile de cara a la globalización, outra ciudad?” In: Actas del Seminario Internacional El desafío de las áreas metropolitanas em um mundo globalizado. Una mirada a Europa y América Latina. Barcelona, 2002. 
MATTOS, Olgária. “A Cidade e o Tempo: Algumas Reflexões sobre a Função Social das Lembranças”. In: Espaço e Debate número 7, 1982, pp 45-52.

MARTINS, J.S. (org.), Henri Lefebvre e o Retorno à Dialética. São Paulo, Editora Hucitec, 1996.

. A Sociabilidade do Homem Simples. São Paulo, Editora Hucitec, 2000.

MARX, K. Manuscritos Económicos y Filosóficos de 1844. Bogotá, Editorial Pluma, 1980.

.Capítulo VI Inédito de O Capital. Resultados do Processo de Produção Imediata. São Paulo, Editora Moraes.

MEYER, R. M. P. et al. São Paulo Metrópole. São Paulo, Edusp/Imprensa Oficial, 2004.

MIELE, S. A. F. Avenida Eng. Luiz Carlos Berrini a produção do “moderno”. Trabalho de Graduação Individual. Departamento de geografia, FFLCH/USP, 2004.

MONBEIG, P. O Estudo Geográfico da Cidade. In: Novos Estudos de Geografia Humana Brasileira. São Paulo, Difusão Européia do Livro, 1957.

NOBRE, E. A. C. Reestruturação Econômica e Território: expansão recente do terciário na Marginal do Rio Pinheiros. Tese de Doutorado, FAU-USP, 2000.

PEREIRA, P. C. X. "Reestruturação imobiliária em São Paulo como chave para o desvendamento da metrópole atual”. In: CARLOS, A. F A. e OLIVEIRA, A. U. (orgs.) Geografias das Metrópoles. São Paulo, Contexto, 2006.

SANTOS, Milton. Metamorfoses do Espaço Habitado. São Paulo, Editora Hucitec, 1988. 
. Metrópole Corporativa Fragmentada: O caso de São Paulo. São Paulo, Nobel, 1990.

. Por uma economia política da cidade. São Paulo, Editora Hucitec, 1994.

SASSEN, Saskia. The Global City. Princeton University Press,1991

A Cidade Global. In: Reestruturação do Espaço Urbano no Brasil. São Paulo, ANPUR/Hucitec, 1993.

SEABRA, O. C. L. "Pensando o processo de valorização a geografia”. In: Boletim Paulista de Geografia, nº 66. São Paulo, AGB, 1988. pp. 97-103.

- “Urbanização e Fragmentação: apontamentos para estudo do bairro e da memória urbana”. In: SPOSITO, M. E. B. (org.). Urbanização e Cidades: Perspectivas Geográficas. Presidente Prudente, Editora da Unesp e GAsPERR, 2001.

SINGER, P. Para entender o mundo financeiro. São Paulo, Contexto, 2003.

SMITH, N. "Gentrification, the Frontier, and the Reestructuring of Urban Space”. In: Readings in urban Theory edited by Susan S. Fainstein and Scott Campbell. Cambridge, Massachsetts, Blackwell Publishers, 1996. Tradução de Daniel Sanfelici.

SOJA, E. Geografias Pós-Modernas. A reafirmação do espaço na teoria social crítica. Rio de Janeiro, Jorge Zahar Editor, 1990.

Postmetropolis. Critical Studies of Cities and Regions. Blackwell

Publishing, 2000.

VAN WILDERODE, D. J. Cidade à venda. Interpretações do processo imobiliário. Tese de Doutorado. FAU/USP, 2000. 